\title{
O ayllu andino nas crônicas quinhentistas
}

\author{
Ana Raquel Portugal
}

PORTUGAL, AR. O ayllu andino nas crônicas quinhentistas [online]. São Paulo: Editora UNESP; São Paulo: Cultura Acadêmica, 2009. 208 p. ISBN 978-85-7983-000-6. Available from SciELO Books <http://books.scielo.org>.

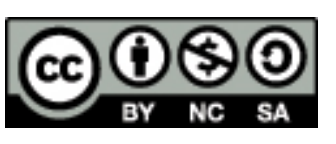

All the contents of this chapter, except where otherwise noted, is licensed under a Creative Commons Attribution-Non Commercial-ShareAlike 3.0 Unported.

Todo o conteúdo deste capítulo, exceto quando houver ressalva, é publicado sob a licença Creative Commons Atribuição Uso Não Comercial - Partilha nos Mesmos Termos 3.0 Não adaptada.

Todo el contenido de este capítulo, excepto donde se indique lo contrario, está bajo licencia de la licencia Creative Commons Reconocimento-NoComercial-CompartirIgual 3.0 Unported. 


\section{- AYLLU ANDINO \\ NAS CRÓNICAS \\ QUINHENTISTAS}

ANA RAQUEL PORTUGAL 


\section{O AYLLU ANDINO NAS CRÔNICAS QUINHENTISTAS}



ANA RAQUEL PORTUGAL

\section{O AYLLU ANDINO \\ NAS CRÔNICAS \\ QUINHENTISTAS}

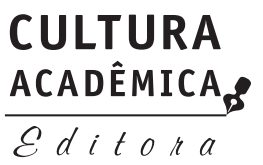


(C) 2009 Editora UNESP

Direitos de publicação reservados à:

Fundação Editora da UNESP (FEU)

Praça da Sé, 108

01001-900 - São Paulo - SP

Tel.: (0xx11) 3242-7171

Fax: (0xx11) 3242-7172

www.editoraunesp.com.br

feu@editora.unesp.br

CIP - Brasil. Catalogação na fonte

Sindicato Nacional dos Editores de Livros, RJ

P885a

Portugal, Ana Raquel

O ayllu andino nas crônicas quinhentistas / Ana Raquel Portugal. - São Paulo : Cultura Acadêmica, 2009.

il.

Anexos

Inclui bibliografia e glossário

ISBN 978-85-7983-000-6

1. Ayllu - História. 2. Índios da América do Sul - Andes, Cordilheia dos, Regiões - Usos e costumes. I. Título.

09-6053.

CDD: 980.41

CDU: 94(873)

Este livro é publicado pelo Programa de Publicações Digitais da Pró-Reitoria de Pós-Graduação da Universidade Estadual Paulista "Júlio de Mesquita Filho" (UNESP)

Editora afiliada:

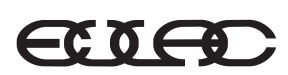

Asociación de Editoriales Universitarias de América Latina y el Caribe

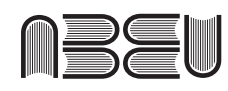

Associação Brasileira de Editoras Universitárias 
Para Anita. 



\section{Agradecimentos}

A realização deste trabalho só foi possível graças à colaboração direta ou indireta de muitas pessoas. Manifesto minha gratidão a todas elas e de forma particular aos professores Pedro Ignácio Schmitz, Maria de Fátima Gouvêa, Eliane Cristina Deckmann Fleck, Maria Cristina Bohn Martins, Ronaldo Vainfas, Ciro Flamarion Cardoso, Franklin Pease, María Rostworowski de Diez Canseco, Luis Miguel Glave, Rafael Varón Gabai, Carmen Arellano Hoffmann, Fernando Silva-Santisteban, Antonio Acosta Rodríguez, Maria Luísa Laviana Cuetos, Berta Ares Queija, Raúl Fornet-Betancourt, Horst Pietschmann, Albert Meyers e Peter Masson.

Agradeço aos funcionários das seguintes instituições a amabilidade no atendimento: Arquivo Geral das Índias, Escola de Estudos Hispano-Americanos, Instituto de Estudos Peruanos, Instituto Francês de Estudos Andinos, Biblioteca da Pontifícia Universidade Católica do Peru, Biblioteca da Universidad Nacional Mayor de San Marcos e Instituto Ibero-Americano de Berlim.

A todos os amigos peruanos, espanhóis e alemães que me auxiliaram na realização desta pesquisa.

À minha família um agradecimento mais do que especial.

O livro aqui apresentado é o resultado de uma pesquisa realizada em diversas etapas e que contou com o apoio finan- 
ceiro do CNPq, da Capes, da Caixa de Socorros D. Pedro V e da Missionswissenschaftliches Institut Missio.

Por fim, agradeço ao Programa de Pós-Graduação em História da UNESP/Franca e à Fundação Editora da UNESP a oportunidade desta publicação. 
¿Quién ha de defender a los pobres indios? Si estos dichos ladrones se meten entre los pobres indios; no hay remedio de ellos en este reino.

(Guaman Poma de Ayala) 



\section{SUMÁRIO}

Apresentação 13

1 O ayllu à luz da história cultural: representação e fronteiras discursivas 27

2 Espanha no tempo da América imaginária 47

3 Revivendo tempos incaicos 69

4 A representação do ayllu pré-hispânico e colonial em crônicas quinhentistas 101

Considerações finais 157

Referências bibliográficas 161

Anexos 181

Glossário 207 



\section{ApresentaçÃo}

Quando usamos a palavra ayllu nos dias atuais, logo pensamos num povoado ou mais propriamente num território demarcado. No século XVI, o ayllu representava a forma de organização de uma população que vivia dispersa e cuja identidade se dava pelos laços de parentesco. Depois de analisar as crônicas quinhentistas, pudemos perceber que o mundo andino deve ser analisado em dois momentos importantes, antes e durante as instalações das reduções toledanas, ocorridas entre as décadas de 1560 e 1570 . Num primeiro momento, o ayllu era o símbolo da união de uma família extensa; já durante as reduções, os nativos foram reagrupados em assentamentos para servirem de mão de obra de fácil acesso e controle. Não foram poucos os casos em que diferentes ayllus terminaram unidos em uma única redução, o que gerou sérios problemas.

Quando demos início ao estudo do ayllu, tomamos por base analisar o conteúdo de seis crônicas do século XVI. Para conseguirmos tal material de pesquisa, fomos ao Peru coletar dados e adquirir bibliografia especializada, já que não dispúnhamos de material no Brasil. Optamos por analisar as crônicas espanholas de Cieza de León (1991), Juan de Matienzo (1967) e José de Acosta (1954), e as crônicas indígenas de Garcilaso de la Vega (1991), Joan Santa Cruz Pachacuti Yamqui Salcamaygua (1993) e Guaman Poma de Ayala 
(1993). De acordo com nossas pesquisas, pudemos constatar que os cronistas espanhóis identificavam o ayllu com genealogia, linhagem e território, e que das propostas de reagrupamento indígena de Matienzo surgiu a identificação de ayllu, redução e comunidade, pois não era mais o sistema de parentesco que interessava, e sim o aldeamento dos índios. Nas crônicas indígenas, encontramos categorias europeias mescladas a padrões culturais andinos, porém os três cronistas interpretaram consensualmente o ayllu, mostrando ser uma estrutura baseada em laços de parentesco de grande importância para a organização do Estado inca.

Como nosso intuito na primeira etapa da pesquisa foi trabalhar o conceito de ayllu e não a sua representação, como passamos a fazer posteriormente e cujo resultado aqui apresentaremos, lançamos mão de estudos contemporâneos sobre essa estrutura que mostravam ser a comunidade indígena atual um fruto da colonização, levando-nos a comprovar que a transformação do conceito de ayllu teria ocorrido no período colonial, tendo como principal fonte a concepção de redução de Matienzo. Naquele primeiro momento, queríamos encontrar uma acepção dessa estrutura, mas o resultado não foi o esperado, pois percebemos que as crônicas apenas nos forneciam pistas, imagens e representações do ayllu, e não um conceito formal. Partindo dessa premissa, elaboramos esta pesquisa que visa aprofundar o estudo do ayllu nas crônicas quinhentistas à luz da história cultural.

Quem primeiro começou o debate sobre o ayllu foi Heinrich Cunow (1929a) no final do século XIX. Esse tema foi estudado por diversos pesquisadores, como Tom Zuidema (1964), Billie Jean Isbell (1974) e Juan Ossio Acuña (1981) etc. Porém, a representação dessa estrutura prossegue pouco explorada, principalmente a partir da confrontação das crônicas do século XVI.

Segundo John Murra, uma das instituições andinas mais debatidas e mais mal documentadas é o ayllu (Murra, 1962). Existem estudos (cf. Uhle, 1911; Valcarcel, 1925; Cunow, 1929a, 1929b, 1933; Steward, 1963; Anavitarte, 1965; Valera, 1976; Lumbreras, 1981; Eich, 1983) que sustentam a ideia da existência do ayllu ou hatha (em quechua ou aymara) desde o período pré-incaico. Nesse perío- 
do, o ayllu seria uma família extensa de linha matrilinear, o que, conforme Carlos N. Anavitarte, explica a presença de mulheres curacas (Anavitarte, 1965). ${ }^{1}$ Com o desenvolvimento da agricultura, os ayllus transformaram-se em patriarcados. Esses ayllus tinham por base estrutural, além dos laços de parentesco, o vínculo religioso. Cada grupo tinha um antepassado comum e também seus próprios deuses e huacas. ${ }^{2}$ O território pertencia a todos os membros do ayllu, e a terra era cultivada comunitariamente por meio da ajuda recíproca. A reciprocidade era a principal característica dos grupos étnicos organizados em ayllus. Essa reciprocidade ${ }^{3}$ inicial se dava entre os membros do ayllu e o curaca, que era o responsável pela divisão da terra a ser cultivada e pelo armazenamento da produção. Suas terras também eram produzidas, bem como as que se destinavam à manutenção das huacas, e o restante dos produtos era redistribuído entre o grupo.

Conforme María Rostworowski, baseando-se nesse tipo de reciprocidade, os incas formaram o seu império, o Tahuantinsuyu, ${ }^{4}$ pois, à medida que ampliavam suas conquistas, o número de curacas unidos ao Inca por reciprocidade e por laços de parentesco foi aumentando, o que resultou num crescimento da força de trabalho disponível (Canseco, 1988a, p.65), aumentando a produção e gerando o excedente necessário à manutenção das ligações recíprocas com os ayllus.

1 Canseco (1988b, p.6-7) afirma que são "numerosas las referencias en documentos de archivos sobre la presencia de mujeres curacas que ejercían directamente el poder durante los siglos XV y XVI [...]".

2 Segundo Canseco (1988a, p.296): "o guaca, templo del ídolo o el mismo ídolo".

3 Para Mauss (1974, p.45, as "prestações e contra-prestações são feitas de uma forma sobretudo voluntária, por presentes, regalos, embora sejam, no fundo, rigorosamente obrigatórias [...]”. Na análise de Marshall Sahlins (1977, p.151), é a necessidade de atender aos imperativos do sistema de reciprocidade que origina o dom. Já para Temple (1989, p.122), o dom e o contradom funcionam como mecanismos propulsores da produção.

4 “[...] (Tawantinsuyu = las cuatro partes del mundo = todo el mundo), llamado imperio de los incas por los cronistas del siglo XVI” (Pease, 1992a, p.35). 
A dificuldade em analisar o ayllu em tempos pré-incaicos reside na falta de dados arqueológicos que comprovem as informações. Uma das obras existentes sobre o assunto é Asto: curacazgo prehispánico de los Andes Centrales, de Danièle Lavallée e Michèle Julien (1983). Essas duas arqueólogas mostraram como a família extensa utilizava uma habitação, conforme os resultados obtidos de um trabalho arqueológico que tratou de reconstruir a ocupação de um sítio em função do agrupamento familiar.

Para analisarmos o período pré-colonial, podemos utilizar as crônicas espanholas e indígenas do século XVI, tendo claro que estamos lidando com representações, e, no caso dos cronistas espanhóis, estes, ao depararem com um mundo distinto do seu, traduziram para sua linguagem tudo o que era relativo ao "outro", o mesmo ocorrendo em relação ao ayllu. O europeu da conquista via o que queria ver e rejeitava aquilo para o qual não estava mentalmente preparado (Elliot, 1984, p.28). Não podemos nos esquecer de que, apesar de pertencerem à Idade Moderna, esses homens, que eram movidos pela ambição de riqueza, estavam imbuídos de categorias do medievo europeu, ligadas à religiosidade, onde o medo do desconhecido levou-os a imaginar um paraíso além-mar (cf. Todorov, 1983; Silva-Santisteban, 1988; Delumeau, 1989; O’Gorman, 1992) e, quando depararam com a América, assimilaram esse Mundus Novus paulatinamente. Nas crônicas indígenas, como na de Guaman Poma de Ayala (1993), encontramos um esquema de funcionamento do ayllu e informações sobre o mecanismo de reciprocidade que o justificam. Sendo esses cronistas espanhóis ou indígenas, o que nos fornecem são imagens do ayllu que nos podem ajudar a tentar compreender a diferenciação entre o ayllu pré-hispânico e o colonial.

Na documentação do século XVI, lê-se que o Tahuantinsuyu nasceu da anexação de diversas etnias, baixo ao controle político-religioso do chefe inca, pois este era o filho do deus Sol. A reciprocidade, como já mencionamos, foi fundamental para a expansão do território inca, tanto que os povos que desconheciam esse sistema não aceitaram a dominação incaica. O Inca estabelecia ligações com os chefes de ayllus oferecendo presentes em troca de trabalho ou, 
como nos mostra John Murra (1978), estabelecendo laços de parentesco, contraindo em casamento filhas desses curacas. Porém, esse sistema tornou-se impraticável por causa das grandes dimensões do império. Desse modo, quando um grupo não aceitava o domínio por meio da reciprocidade, o Inca colocava um funcionário de sua confiança no lugar do curaca local, estabelecendo, assim, suas regras organizativas. $\mathrm{O}$ aumento do território e da população ocasionou a necessidade de maior produção para ser redistribuída e atender ao sistema de reciprocidade.

Polanyi et al. (1957) aplicam os conceitos de reciprocidade e redistribuição no estudo de populações africanas, e John Murra (1983) os reutiliza, caracterizando o Tahuantinsuyu como sendo um Esta$\mathrm{do}^{5}$ redistributivo, não porque fosse um Estado com fins humanitários, mas porque isso era essencial para manter a coesão do império. Isso ocasionou mudanças na organização produtiva dos ayllus, pois, se antes a reciprocidade e a redistribuição se davam com base nas relações de parentesco entre o chefe do ayllu e seus membros, depois passaram a ocorrer basedas na relação político-religiosa estabelecida entre esses grupos e o Estado inca (Godelier, 1977).

Durante o domínio inca, os ayllus permaneceram como grupos ligados por laços de parentesco, e aqueles que tinham a posse da terra perderam-na, passando esta ao controle do Estado, que, por sua vez, a dividiu em terra do Sol, do Estado e do povo. A cada ano era feita a redistribuição de tupus, lotes de terra suficientes para o

5 "Desde el punto de vista antropológico, como político, y tal como lo define Kelsen, 'el Estado es una sociedad políticamente organizada bajo un ordenamiento coercitivo'. Es exacta la definición del célebre jurista, puesto que al decir 'politicamente organizada' se está refiriendo a sociedades cuya organización incluye varios linajes, clanes o tribus, y la organización 'política' empieza con la unión, domínio o cooperación de grupos distintos por encima de los lazos de parentesco; y al decir 'coercitivo' alude a la característica fundamental del Estado señalada por Max Weber, quien lo definió como 'la asociación humana que reclama para si, con éxito, el monopolio legítimo de la fuerza física'. Como quiera que se lo interprete el Estado está relacionado con el poder político y con el control de los excedentes de la producción" (Silva-Santisteban, 1994, p.296-7). 
sustento de cada família. Também eram distribuídas as tarefas de produção estatal da terra, pois esse tipo de trabalho, ou mita, era o tributo que o Estado exigia da população em troca de benefícios coletivos ou individuais. Desse modo, o sistema comunitário de produção baseado em laços de parentesco do ayllu é reutilizado no Tahuantinsuyu com fins expansionistas.

Muitos grupos étnicos permaneceram insatisfeitos sob o domínio inca, pois também foi utilizada a coerção. O crescimento em demasia do território dominado originou uma maior demanda de produtos para serem redistribuídos, e nem sempre o Inca conseguiu satisfazer os curacas, que esperavam dele presentes e regalias. Esse descontentamento vai se refletir na chegada dos espanhóis, pois muitos desses curacas aliaram-se ao inimigo com o objetivo de libertarem-se do jugo incaico e de estabelecerem novas relações de reciprocidade.

Quando Francisco Pizarro chegou a Tumbez, em 1532, o Tahuantinsuyu estava dividido pela disputa dos dois irmãos, Huascar e Atahualpa, pela mascapaicha. O Inca Huayna Capac havia ido guerrear no norte do território incaico e aí morreu vítima de uma epidemia de varíola e sarampo. Huascar era considerado o melhor candidato a substituir seu pai, visto que ele era filho do Inca com a coya, esposa principal. Ao contrário do que ocorria nos ayllus comuns, em que o sistema era patrilinear e exogâmico, entre as panacas ou ayllus reais a linha de descendência era matrilinear e endogâmica. Porém, apesar da aparente desvantagem de Atahualpa, ele tinha direito a disputar o poder, pois também era filho do Inca. Depois de alguns confrontos com seu irmão, Atahualpa terminou por vencê-lo.

Atahualpa encontrava-se em Cajamarca quando Pizarro chegou e o aprisionou. A conquista do povo inca se deu de modo aparentemente fácil, pois este não ofereceu resistência, já que não foi atacado. A falta de coesão diante do perigo, a insatisfação de alguns chefes étnicos em relação ao Estado e a debilidade diante do armamento espanhol foram alguns dos fatores que propiciaram a sua derrota. 
Depois da conquista inicial, começaram a aparecer os primeiros documentos que descreveram não só os feitos dos espanhóis, mas também as organizações das etnias encontradas no que hoje conhecemos por Peru.

O século XVI é extremamente complexo de ser analisado, pois, como afirma Luis Millones (1981), esse período é o mais importante da história americana porque aconteceram grandes mudanças. A maioria dos pesquisadores se concentra no estudo desse século, havendo quem se dedique a um estudo diacrônico da sociedade andina desde a época pré-hispânica até os dias atuais. No caso específico das pesquisas sobre o ayllu, dispomos de importantes estudos que procuram, na evolução histórica dessa estrutura, compreender como se originou a atual comunidade indígena (cf. Hoffmann, 1988, 1990, 1994).

Um trabalho de destaque é a tese de doutorado de José María Arguedas (1968), na qual esse pesquisador procurou provar que as comunidades indígenas contemporâneas são resultado das transformações ocorridas no período colonial. Nessa época, o vice-rei Toledo mandou reagrupar diversos ayllus em reduções, que seriam "sobrevivências" das comunidades de Castela no Peru, com o intuito de evitar que os índios fossem explorados só por encomendeiros e garantir o seu aproveitamento para a economia real. Fuenzalida Vollmar (1976), como Arguedas, crê que a comunidade indígena teve origem no período colonial, mas acrescenta que o ayllu, como família extensa, vira uma cofradía, ${ }^{6}$ ou seja, une laços parentais aos rituais cristãos. Esses estudos partiram da análise de problemas e regiões concretas, o que, por vezes, provoca uma fragmentação dos conhecimentos, acentuando as diferenças regionais e distorcendo a realidade andina pré-hispânica, colonial e contemporânea (Cock, 1981, p.232-3).

Por haver poucos estudos sobre o ayllu no século XVI, faz-se necessária uma busca das interpretações encontradas em documenta-

6 Segundo Celestino (1981, p.300), cofradía “[...] se destingue de la comunidad porque se funda primeramente con fines religiosos". 
ção desse período, a fim de perceber o que esses cronistas entendem por ayllu e como se deu a transformação do ayllu pré-hispânico, que era um sistema de parentesco para o ayllu colonial de base territorial.

Em síntese, antes da chegada dos espanhóis, o ayllu era um grupo ligado por laços de parentesco, além de outras características já tratadas, e que, sob o domínio incaico, foi inserido num contexto maior, tendo por função o sistema produtivo do Estado inca. No período colonial, o ayllu aparece nos relatos de cronistas não apenas como linhagem, mas também como povoado, acrescentando assim novas representações. Depois das reduções toledanas, também muda a sua organização, e o ayllu passa a representar não apenas uma unidade de parentesco, mas também uma unidade política territorial em que o objetivo foi proporcionar mão de obra disponível para as tarefas coloniais.

As reduções do vice-rei Toledo ocorreram a partir de 1560, por isso é importante analisar documentação relativa a todo o século XVI. Desse modo, poderemos realizar um estudo das diversas representações dadas ao ayllu por espanhóis e indígenas que o descreveram desde o período da conquista e também quando essa estrutura foi inserida no contexto político colonial.

Os cronistas espanhóis, ao tratarem o assunto, não estavam apenas influenciados pela realidade colonial peruana, mas também por critérios trazidos da Espanha, como a concepção que tinham de suas próprias comunidades camponesas. Isso, a nosso ver, deve ter sido determinante nas representações dadas ao ayllu. Por meio de um estudo da confluência de discursos dos cronistas desse período a respeito do ayllu, procuraremos coletar informações com o propósito de perceber o que se confirma e o que se contradiz nesses documentos. A partir daí, poderemos tentar perceber como se deu a identificação de ayllu com comunidade e redução na passagem do período pré-hispânico para o colonial.

Conforme opiniões pessoais coletadas junto a pesquisadores peruanos, alemães e espanhóis, não existe nada sobre o que os cronistas entendem por ayllu e por quê. Existem sínteses sobre a historiografia andina, em que seus autores abordam o conteúdo geral das 
crônicas sobre a história do Tahuantinsuyu (Valcarcel, 1964; Wedin, 1966; Barrenechea, 1986), mas nenhuma pesquisa que trate especificamente da representação tida por tais cronistas a respeito do ayllu.

Existem diversas obras de antropólogos e historiadores que tratam da evolução do ayllu. Muitos deles acreditam que a comunidade indígena atual tem sua matriz nas reduções toledanas.

Para Matos Mar (1976b), a comunidade não só era resultante da reestruturação espanhola dos povos indígenas a partir dos antigos ayllus, como também o era da evolução colonial e republicana. Arguedas (1968) foi um dos precursores nessa temática, utilizando fontes documentais, como crônicas e descrições geográficas, para comprovar sua tese de que a comunidade indígena era fruto de uma aplicação da comuna espanhola do século XVI. Depois dele, como já comentamos, Fuenzalida Vollmar (1976) também traçou a evolução da comunidade indígena durante a época colonial.

Os historiadores têm enfocado esse tema baseando-se em estudos sobre o Tahuantinsuyu. Heinrich Cunow produziu um trabalho pioneiro ao comparar o ayllu com a comunidade germânica, mas sua tese não foi comprovada, dando origem a diversas discussões (cf. Pease, 1981). Cunow (1929a, 1929b, 1933) também analisou o sistema de parentesco e a organização social incaica.

Outros trabalhos importantes sobre o ayllu datam do princípio do século XX. Pesquisadores como Tudela Valera (1905), Uhle (1911), Saavedra (1913), Eguiguren (1914) e Cuneo Vidal (1977) perceberam a importância dos estudos sobre ayllu para uma compreensão do mundo incaico e as transformações ocorridas com essa estrutura, embora tenham utilizado pouco as crônicas.

Por volta de 1920, surgiu no Peru o movimento indigenista que tinha por objetivo refletir sobre as questões indígenas (Marzal, 1989). Nesse período, Castro Pozo (1924, 1963, 1973) escreveu sobre a evolução do ayllu, partindo da situação do índio nas reduções, mas usa poucas fontes documentais e mais obras secundárias.

Os trabalhos que apareceram até a década de 1950 trataram da origem do ayllu e de sua evolução até o Tahuantinsuyu (cf. Urteaga, 1931; Riva-Agüero y Osma, 1937; Valcarcel, 1925, 1959). O ayllu 
foi definido como uma unidade de parentesco que tinha caráter totêmico e de exploração comunitária da terra. Depois dos anos 1950, apareceram estudos que mudaram a forma de analisar essa temática. Para Franklin Pease (1978, p.24-5), foram John Rowe, María Rostworowski e John Murra os responsáveis pela ampliação da perspectiva usada para analisar as populações indígenas durante a Colônia, insistindo os dois últimos na precisão das unidades étnicas e em sua permanência na história. $\mathrm{O}$ ayllu passou a ser analisado dentro da organização política dos grupos étnicos, dando origem aos estudos regionais dos etno-historiadores. Por meio dos estudos de Canseco (1972, 1977, 1978a, 1978b) e Murra (1975), sabe-se hoje que existem diferenças entre os ayllus da costa (norte e central) e da serra (central e sul). Para Cock (1981, p.237), a “coesão social” é uma característica de todos os ayllus, na qual se expressam relações de parentesco, rituais, sociais e econômicas (cf. também Eich, 1983, p.85).

Mesmo com a grande quantidade de dados já coletados sobre o ayllu, ainda é necessário prosseguir os estudos das interpretações cronísticas. Atualmente, os pesquisadores podem contar com grande quantidade de documentos publicados, como crônicas, visitas, litígios, que, em sua maioria, são parte de artigos ou teses de etno-historiadores (cf. Canseco, 1977, 1978a, 1978b).

Com a ampliação das fontes documentais à disposição, apareceram muitos trabalhos regionais, como os de Canseco (1977, 1978a, 1978b) sobre a costa norte e central; Spalding (1967) sobre Huarochiri; Murra (1975) para Huánuco; e Pease (1981) para Arequipa.

A documentação administrativa colonial é utilizada por estudiosos que visam compreender o papel do curaca como intermediário entre os ayllus e os espanhóis. Existem alguns trabalhos que tratam desse tema (cf. Varón Gabai, 1980; Canseco, 1983), porém não oferecem informações sobre a estrutura política interna dos ayllus, como a relação tida entre os curacas menores.

As visitas de Ortiz de Zúñiga $(1967,1972)$ e Diez de San Miguel (1964) são fontes importantes para analisar a estrutura familiar e a organização socioeconômica de grupos étnicos. Foi por meio dessas 
visitas que Murra (1972) elaborou sua teoria de "controle vertical" de pisos ecológicos na economia andina. Canseco (1977, p.16-9) provou que também existem grupos étnicos costenhos que não obedecem a esse sistema serrano, pois são sociedades especializadas que não dependem de ecologia diferenciada.

O sistema de parentesco, segundo Mayer \& Bolton (1980), foi analisado por vários pesquisadores, como Rowe (1963) e Zuidema (1964, 1966, 1991), que se dedicaram à análise do parentesco inca. Essa limitação se dá por causa da quase inexistência de documentação sobre outras etnias.

Outro aspecto importante para a compreensão do ayllu é o sistema religioso, pois, a partir do momento em que essa estrutura foi integrada à realidade colonial, houve uma sobreposição do culto católico ao andino. O culto andino conseguiu persistir, segundo as análises de Celestino \& Meyers (1981) e Duviols (1977) sobre as cofradias e idolatrias.

Para realizarmos nosso trabalho, começamos por selecionar os cronistas, tendo em vista que estes sofreram várias influências. No caso dos cronistas espanhóis, sabemos que estes se basearam em sua própria concepção de comunidade camponesa para tratar do ayllu. Quanto aos cronistas indígenas, verificamos que estes foram alvos do processo de "aculturação", o que transparece em seus escritos. Fizemos levantamento e revisão de bibliografia secundária sobre essa temática em bibliotecas brasileiras e coletamos para análise material documental e bibliográfico em arquivos, institutos e bibliotecas do Peru, da Espanha e da Alemanha. Isso se fez necessário por causa da inexistência de fontes primárias no Brasil que permitissem a realização desta pesquisa, bem como de grande parte da bibliografia especializada aqui utilizada.

Analisamos crônicas, algumas visitas, relações geográficas, dicionários coloniais e demais documentação primária, o que permitiu uma aproximação à representação do ayllu realizada por esses cronistas. As crônicas são uma fonte valiosa de informação tanto etnográfica como histórica sobre os povos andinos dos períodos pré-hispânico e colonial. Os dados recolhidos nesses documentos têm 
de ser interpretados partindo da percepção das fronteiras discursivas que vislumbramos nos textos escritos por espanhóis e indígenas, onde estes utilizam o recurso da familiaridade no processo de alteridade.

Os espanhóis, por exemplo, transformaram o sistema político numa monarquia, e sabemos que, no mundo incaico, o governo era dual, existindo dois incas e dois curacas (cf. Duviols, 1979, 1980; Pease, 1992a, 1992b). A sucessão incaica, ao contrário do que escreveram os cronistas, não era via filho legítimo e primogênito como na Europa do século XVI, e sim pelo "mais hábil” (Canseco, 1993). Outro exemplo da dificuldade em analisar essas crônicas está no conceito de "pobreza". Para os cronistas espanhóis, "pobres" eram os velhos e aleijados que não tiveram acesso a bens, enquanto, no mundo andino, "pobres" eram os incapacitados de trabalhar temporariamente ou indefinidamente (Varón Gabai, 1980, p.10).

Os cronistas indígenas descreveram seu mundo baseados em critérios europeus, visto que passaram por um processo de "aculturação". Entendemos por processo de "aculturação" um movimento de adaptações, assimilações, reelaborações e inclusive recusas e ações contra-aculturativas. Em termos gerais, entende-se por aculturação o conjunto de fenômenos que resultam do contato direto e contínuo de grupos que participam de culturas diferentes (Silva-Santisteban, 1988, p.147-50).

Nathan Wachtel (1976a, 1976b), grande estudioso da história do Peru, abordou em várias obras o conceito de aculturação, deixando transparecer uma tendência a colocar em oposição tradição e aculturação, o que leva a uma simplificação do processo de absorção dos novos elementos culturais, considerados superficiais e desestruturadores (cf. também Almeida, 2000, p.45).

Já Steven Stern (1987), ao abordar as mudanças ocorridas com os índios que ficaram perante os ocidentais, prefere denominar esse processo de resistência adaptativa, em que os índios procuraram as melhores condições de sobrevivência. Para contrastar, temos ainda o posicionamento de Serge Gruzinski (1986) que considera as mudanças culturais propícias à reorganização e resistência indígena, pois 
a colaboração e adaptação à nova realidade eram fundamentais como métodos de sobrevivência cultural. Entendemos então que as crônicas redigidas por indígenas, mesmo sendo fruto de uma visão aculturada, não representam o mundo andino de forma distorcida ou preconceituosa, muito pelo contrário, algumas constituíram verdadeiros discursos apologéticos e de resistência cultural.

As crônicas de maior interesse para nossa pesquisa são as que abarcam o período de 1532 até princípios do século XVII, por ser o período em que os cronistas escreveram sobre o ayllu pré-hispânico e colonial. O período inicial de colonização é o de maior interesse, pois é quando o ayllu sofre uma transformação estrutural consolidada no período das reduções toledanas, ou seja, de primordialmente baseado em sistema de parentesco, o ayllu passa a ter por base um espaço territorial definido.

Utilizamos bibliografia secundária produzida por historiadores, antropólogos, etnólogos e arqueólogos que estudaram o mundo andino e analisaram o ayllu. Revisamos algumas pesquisas regionais sobre a comunidade camponesa espanhola do século XVI, bem como demais características europeias, que nos ajudaram a compreender as interpretações de ayllu dos cronistas espanhóis.

A limitação cronológica se deu também porque cremos que as obras do século XVI possuem uma coerência temática, em que se abordam os feitos da conquista, as características humanas e naturais do Novo Mundo e o começo do processo de "aculturação". Os cronistas espanhóis e indígenas interessaram-se em melhorar o conhecimento sobre o passado andino, detendo-se, inclusive, em estudos de âmbito local. Como analisamos antes, é nesse período que os cronistas espanhóis se confrontam com os indígenas (Gruzinski, 1995; Elliot, 1984, 1990), necessitando aprender a conhecer e reconhecer o outro. Depois de estabelecido o contato inicial e começado o processo de colonização, cronistas indígenas e espanhóis passaram a abordar o mundo andino e, como nos interessa, o ayllu, que é então representado de distintas formas.

O problema principal de nossa pesquisa é saber quais as representações dadas ao ayllu no século XVI por cronistas espanhóis e in- 
dígenas e por quê. Para tanto, nossa abordagem teórica baseou-se nas premissas da história cultural de Chartier (1990, p.28), que tem por objetivo "compreender as práticas, complexas, múltiplas, diferenciadas, que constroem o mundo como representação". Para Chartier (1990, p.17), as representações do mundo social são construídas pelo grupo que as forja, conforme seus interesses, com a finalidade de impor sua concepção de mundo, seus valores e seu domínio.

Apresentamos aqui uma história das representações de ayllu encontradas em documentos espanhóis e andinos. Os espanhóis como conquistadores interpretaram essa estrutura de forma a facilitar sua organização colonial. Já os cronistas indígenas mostraram como funcionava o ayllu, pois seu mundo estava organizado em torno dessa estrutura. Porém, por serem contemporâneos dos conquistadores espanhóis, muitas vezes seus escritos deixaram transparecer a aculturação sofrida por estes ou ainda traçaram discursos apologéticos numa tentativa de lutar pelos seus direitos.

Nosso estudo tem a finalidade de mostrar que o ayllu pré-hispânico era geralmente composto por uma família extensa que formava um grupo local detentor ou não de um território utilizado comunitariamente para subsistência de seus integrantes e que, no período colonial, adquiriu um caráter primordialmente territorial com a finalidade de armazenar mão de obra. Sendo a concepção de comunidade uma organização medieval europeia, esta se confunde com as reduções do vice-rei Toledo, originando a ideia de ser o ayllu uma comunidade, o que antes das reduções não existia. Isso pode ser comprovado por meio da comparação dos discursos encontrados nas crônicas produzidas nos séculos XVI e XVII.

Procuramos, então, mostrar que, nas fronteiras discursivas das crônicas quinhentistas, está representado o ayllu colonial como mescla de traços culturais andinos e espanhóis. 


\section{1 \\ O AYLLU À LUZ DA HISTÓRIA CULTURAL: REPRESENTAÇÃO E FRONTEIRAS DISCURSIVAS}

Ao mergulharmos no imaginário do século XVI, pelas linhas de cronistas que outrora relataram seus feitos e suas impressões a respeito de si e do outro, deparamos com a dificuldade inerente àquele que trabalha com uma utensilagem mental (Fevbre, 1988, p.328) diferente da sua. Para descobrirmos as representações coletivas do outro, temos que nos despir dos hábitos mentais próprios do século XX e procurar compreender as palavras e os símbolos que representam a psique coletiva do homem do século XVI (Chartier, 1990, p.37).

Conhecer o mundo andino aos olhos de europeus colonizadores e de ameríndios aculturados (cf. Stern, 1987; Wachtel, 1976a, 1976b) é uma tarefa árdua que remete a discussões teóricas em torno do discurso utilizado por tais cronistas. Sabemos que esses discursos foram, por vezes, forjados para atender às necessidades coloniais, mas também são resultantes das práticas culturais entre esses povos. A história cultural aborda essa problemática procurando perceber as representações culturais de cada grupo e o porquê de as assim terem construído. 


\section{Interpretações sobre história cultural}

O renascimento da narrativa historiográfica (Burke, 1992b, p.326-48) permite que o historiador faça conjecturas na falta de comprovação dos dados, desde que deixe evidente esse procedimento (Ginzburg, 1991a, p.179-202). Tal metodologia, a nosso ver, reflete a problemática em torno da concepção da história como forma de conhecimento. O historiador trabalha com documentos representativos de uma determinada época que de forma alguma são uma prova verossímil dessa realidade. Esses documentos fornecem-nos apenas indícios, pistas (ibidem, 1990, p.143-79) do que poderá ter acontecido no passado. Cabe ao historiador saber interpretá-los. Poderíamos afirmar então que a história é uma forma de interpretação de signos, pois o historiador trabalha com narrativas não de acontecimentos puros e simples, mas, sim, de cruzamentos culturais humanos. Foucault (1997) vê, no jogo de discursos, o meio de apreender as transformações (cf. O’Brien, 1992, p.52) culturais, visto que, para ele, o homem está condicionado historicamente pelo coletivo, ou seja, o desejo individual é condicionado pelo indivíduo, ${ }^{1}$ deixando o homem de ser o sujeito histórico e passando a ser sujeito da enunciação. Para nós, embora o homem represente sua realidade conforme seus condicionamentos inconscientes, continua sendo ele o mentor de tais discursos, e, por isso, é o sujeito histórico.

A história tradicional ${ }^{2}$ baseava-se em documentos oficiais para abordar a história dos acontecimentos políticos que ocorriam numa esfera individual (Burke, 1992a, p.10-3). Isso acarretava uma visão

1 Nos volumes II e III de História da sexualidade, Foucault (1999), com base em um referencial histórico que parte da Antiguidade greco-romana e não somente do Renascimento, retoma a ideia de um sujeito com desejos, como o fez em outras obras.

2 Sobre a história tradicional, Peter Burke (1992c, p.17) afirma: "A forma dominante, porém, tem sido a narrativa dos acontecimentos políticos e militares, apresentada como a história dos grandes feitos de grandes homens-chefes militares e reis. Foi durante o Iluminismo que ocorreu, pela primeira vez, uma contestação a esse tipo de narrativa histórica”. 
oficial, unilateral e, por vezes, positivista dessas fontes documentais. A nova história, ${ }^{3}$ ao contrário, volta-se para a análise das estruturas, procurando novas evidências e a interdisciplinaridade para analisar o coletivo (ibidem, p.12-6). Em alguns casos, a descrição densifica-se, como no caso da micro-história, em que há uma redução da escala de observação e um estudo intensivo do material documental (Levi, 1992, p.136). Esse é um procedimento analítico que nos reporta à teoria de Geertz (1989, p.13-41), que realiza uma descrição densa do comportamento público, procurando o conteúdo simbólico da ação e o particularismo. Essa análise cultural é estática, pois limita-se a uma constatação, despreocupada com a mecânica do poder. Já Sahlins (apud Burke, 1992a, p.346) analisa dialeticamente as estruturas e os acontecimentos, fazendo uso do acontecimento para revelar as estruturas da cultura.

A história cultural surge como resposta às necessidades metodológicas da nova história, pois, se esta está fragmentada por causa das novas propostas de analisar as estruturas e trabalhar o coletivo por meio da heteroglossia (Burke, 1992a, p.14-6), é a cultura que vai ser utilizada como base para esses procedimentos. Na história cultural, preocupada com caminhos alternativos, temos diferentes modelos de análise que trabalham as interpenetrações culturais (Vainfas, 1997, p.152) por meio da representação e do conflito de discursos culturais.

Chartier (1990, p.28) analisa a representação em relação ao mundo social como sendo um conjunto de práticas culturais em que os atores sociais interagem produzindo uma cultura específica. Desse

3 A nova história é resultado da contribuição do grupo dos Annales, que "[...] ampliou o território da história, abrangendo áreas inesperadas do comportamento humano e a grupos sociais negligenciados pelos historiadores tradicionais. Essas extensões do território histórico estão vinculadas à descoberta de novas fontes e ao desenvolvimento de novos métodos para explorá-las. Estão também associadas à colaboração com outras ciências, ligadas ao estudo da humanidade, da geografia à lingüística, da economia à psicologia. Essa colaboração interdisciplinar manteve-se por mais de sessenta anos, um fenômeno sem precedentes na história das ciências sociais" (ibidem, p.126-7). 
modo, as práticas de apropriação cultural permitem formas diferenciadas de interpretação. Para Chartier, as relações econômicas e sociais estão inseridas nesse campo de práticas culturais (Hunt, 1992, p.9), deixando de lado a dicotomia cultura letrada e cultura popular e a diferenciação entre análise interna individual e abordagem externa coletiva.

Inspirado na obra de Mikhail Bakhtin (1993) sobre Rabelais, em que aparece implícita a noção de circularidade, Ginzburg (1991b) propõe abertamente esse conceito ao utilizá-lo para tratar os conflitos culturais ocorridos entre os representantes da cultura popular e da letrada (cf. Vainfas, 1997, p.152). Para Ginzburg (1991b, p.22), é por meio dessa circularidade cultural que se originam as formações sociais híbridas, como exemplificado no estereótipo do sabá apresentado no livro História noturna. ${ }^{4}$

Segundo Chartier (1990, p.16-7), a história cultural tem, portanto, "por principal objecto identificar o modo como em diferentes lugares e momentos uma determinada realidade social é construída, pensada, dada a ler". Reiteramos nosso posicionamento ao procurarmos interpretar os signos culturais que nos são deixados em crônicas e documentos antigos, rejeitando uma simples constatação e analisando a narrativa a respeito dos acontecimentos da época e também o resultado das trocas culturais representadas nesses textos. É na confluência dos discursos letrados e populares que buscaremos tais realidades culturais e sociais.

$\mathrm{Na}$ apropriação cultural, ao interagirem, os atores sociais realizam a dinâmica da produção de cultura. Ao utilizarmos textos antigos originados nesse processo, conforme a teoria de Chartier (1992, p.218-9), devemos analisá-los tendo claro que o relato falado é diferente do texto impresso, bem como o ato de escrever é distinto da confecção de um livro. As práticas de impressão permitem a consolidação de sociabilidades e a determinação de comportamentos

4 Ao analisar a história da santidade ameríndia de Jaguaripe, Ronaldo Vainfas (1995, p.228) a define como exemplo de hibridismo cultural e triunfo do colonialismo. 
(ibidem, p.228). Ao analisarmos as crônicas do século XVI que tratam da história andina no período da conquista, estamos lidando com um conjunto de informações que são a representação desse mundo indígena, aos olhos de europeus, mestiços e autóctones impregnados de traços culturais espanhóis. Podemos considerar que os textos resultantes dessa apropriação cultural representam uma nova realidade, que acabará por ser assimilada e sociabilizada.

Complementando o posicionamento teórico de Chartier, lançamos mão da circularidade cultural que Ginzburg observa entre letrados e populares, para analisarmos as crônicas. Chartier não admite essa dicotomia, porém, é no entrecruzamento cultural erudito e folclórico que podemos vislumbrar a formação de uma cultura específica. Dificilmente, dentro de um círculo cultural popular sem influência externa de traços culturais eruditos, poderá formar-se outra representação cultural. A oposição faz-se necessária para desconstrução e construção de novos parâmetros culturais, sem que as características básicas de cada cultura sejam completamente perdidas. Se as fronteiras são criadas pelas exigências da interação social (Guibernau, 1997, p.91), acreditamos que fronteiras discursivas aparecem nessa interação cultural.

\section{Cronistas quinhentistas e o ayllu andino}

A alteridade está expressa nas crônicas espanholas do século XVI, pois retratam o relacionamento do "eu" com o "outro", mostrando primeiro o julgamento de valor que os conquistadores faziam, aproximando-se ou distanciando-se, e depois conhecendo ou ignorando por completo a identidade do "outro". Os espanhóis perceberam que a comunicação estava ligada ao poder e que o domínio dos signos autóctones podia propiciar a conquista. Baseados nessa concepção, procuraram compreender o "outro" para dominá-lo e depois destruí-lo. ${ }^{5}$

5 A questão da alteridade é analisada por Tzvetan Todorov (1983). 
Ao conquistarem o Tahuantinsuyu, mais conhecido como império inca, não foi diferente. $\mathrm{O}$ espanhol que aí chegou ou desprezou essa nova cultura ou procurou conhecê-la, comparando-a a características familiares (Mello e Souza, 1993, p.26), para então dominar essa população. Do relacionamento entre espanhóis e a população local, frutificaram muitas representações culturais expressas em documentos e crônicas quinhentistas. Houve, sim, uma desestruturação ${ }^{6}$ do mundo indígena, mas, por causa das fronteiras discursivas em que essas culturas antagônicas puderam encontrar-se, eclodiu uma cultura que poderíamos denominar híbrida, segundo Ginzburg, ou mestiça, conforme Gruzinski (1995). ${ }^{7}$

Para exemplificarmos essa dinâmica cultural, que foi expressa de forma discursiva por cronistas, abordaremos as mudanças ocorridas com o ayllu andino no período inicial da colonização espanhola. O ayllu é uma estrutura indígena que, no período pré-colonial, conformava um grupo ligado por laços de parentesco, possuidor ou não de um espaço territorial delimitado (Portugal, 1995b, p.97). Era também o símbolo do inconsciente coletivo andino, a unidade simbólica mítica, social, econômica e política. Os cronistas espanhóis ${ }^{8}$ apropriaram-se do significante e não do significado do ayllu, permitindo diversas interpretações aculturadas. Esses cronistas descreveram o ayllu de acordo com seus critérios mentais, conferindo-lhe, por vezes, uma conotação territorial baseada em suas próprias concepções de comunidade camponesa. Essa prática deveu-se não apenas à incompreensão diante de um mundo organizado de forma distinta do seu, mas também à necessidade de atender a interesses que viabilizaram o sistema organizativo colonial.

6 “"...] por el término de 'desestruturación' entendemos la supervivencia de estructuras antiguas o de elementos parciales de ellas, pero fuera del contexto relativamente coherente en el cual se situaban [...]" (Wachtel, 1976b, p.135).

7 "El mestizaje no fue sólo yuxtaposición o adición. Pudo generar formas culturales nuevas que se ubicaron más allá de la tradición americana y de las importaciones occidentales" (Gruzinski, 1994, p.169).

8 Sobre a acepção de ayllu tida pelos cronistas espanhóis Cieza de León (1551), Juan de Matienzo (1567) e José de Acosta (1590), ver Portugal (1996). 
A colonização espanhola na região andina implantou um sistema monárquico centralizador, para o qual era necessário o controle das comunidades locais. Para tanto, era necessário convencê-las, tornar natural (Bourdieu apud Campos 1998, p.65-6) a sua supremacia, inserindo o ayllu nos padrões europeus de comunidade camponesa. Esperava-se com isso que os chefes locais passassem a prestar obediência aos representantes da coroa espanhola, seguindo as normas estabelecidas e expressas nos discursos que atendiam aos interesses institucionais. A concepção territorial auferida ao ayllu não foi apenas um resultado da incompreensão da simbologia indígena por parte dos espanhóis, mas, principalmente, um instrumento de controle social e econômico.

No período colonial, o ayllu configura-se como um espaço territorial, ${ }^{9}$ visto que é durante o período toledano que vários ayllus são reagrupados para conformar reduções, conferindo-lhes um caráter espacial (Portugal, 1996, p.99). O ayllu colonial poderia tratar-se apenas de um resultado de práticas culturais compartilhadas entre os diferentes grupos, porém, por causa das diversas representações a ele atribuídas pelos cronistas desde o período da conquista, conjecturamos que tais discursos também atendiam à necessidade de legitimar o poder espanhol, convertendo o ayllu em núcleo produtivo e passível de controle. ${ }^{10}$ As crônicas indígenas ${ }^{11}$ de que dis-

9 A respeito da concepção territorial atribuída ao ayllu por cronistas do século XVI, ver Pease (1981), Canseco (1981) e Soriano (1981).

10 "They therefore wanted the Indians in accessible locations near their farms and mines, so that they could have no pretext for resistance. Thus, under the guise of aiding, instructing, and indoctrinating them 'in order that they shall not live scattered in the lands and forests, deprived of all spiritual benefit and of living in good order (policia)', their reduction (reduccion) was ordered. This consisted of compelling them to abandon villages, which were located on their original marcas (communal lands), to move to open, flat places, which the conquerors chose. The new towns established on these locations included the inhabitants of two, three or more ayllus which were thus reduced to only one comunity" (Castro Pozo (1963, p.489).

11 Sobre a conotação de ayllu entre cronistas indígenas Garcilsaso de la Vega (1609), Joan de Santa Cruz Pachacuti (1613) e Guaman Poma de Ayala (1615), ver Portugal (1996, p.95-8). 
pomos foram redigidas durante o período colonial por indivíduos que viveram um processo de aculturação, em que sua utensilagem mental mesclou-se a traços culturais europeus, originando um discurso mestiço. ${ }^{12}$

O ayllu colonial é representado nessa fronteira discursiva, em que as visões europeia e indígena se encontram, dando origem a essa nova concepção. Fronteiras são simbólicas e construídas pela necessidade de diferenciação entre grupos, que se reconhecem entre si, por meio de traços culturais representados em sinais, símbolos e discursos. Quando culturas diferentes interagem, essas fronteiras rompem-se parcialmente, permitindo o surgimento de representações culturais distintas.

As crônicas do século XVI representam o resultado da confluência de discursos culturais distintos. O processo de alteridade vivido por espanhóis e indígenas, em que ambos procuram conhecer o outro recorrendo a referências culturais familiares, demonstra a existência de fronteiras discursivas propícias a uma interação cultural.

Numa análise contemporânea sobre fronteiras culturais da nação, Komi Bhabha (1995, p.4, 27) afirma que as fronteiras são entrelugares, através dos quais as significações de autoridade cultural e política são negociadas e que, na diferença cultural, estabelecem-se novas formas de significado e estratégias de identificação, onde não se pode estabelecer uma autoridade discursiva sem que a própria diferença seja revelada.

Aplicando-se essa premissa à análise das crônicas quinhentistas, percebemos que essas narrativas são resultantes da negociação de diferenças e familiaridades ocorridas na fronteira discursiva dessas

12 "Junto con las crónicas españolas existen también relatos escritos por indígenas o mestizos durante la época colonial: Titu Cussi Yupanqui, Guamán Poma de Ayala, Joan de Santa Cruz Pachacuti y Garcilaso de la Vega. Algunos investigadores han acentuado las características 'andinas' de estos escritores, privilegiando la fuerza de la sangre sobre la educación. La visión que estas narraciones nos brindan sobre el mundo indígena y colonial es una visión mestiza, que trata de conciliar el pasado con los principios universales del cristianismo" (Bernand, 1994, p.71-2). 
culturas. Essas fronteiras são perceptíveis e marcantes, mas permitem a formação de um discurso cultural híbrido.

Para garantir a inteligibilidade de uma mensagem, é necessário o reconhecimento de discursos desterritorializados (Ortiz, 1996, p.128). Ao utilizarem referências culturais comuns, os cronistas espanhóis e indígenas do século XVI procuraram, a princípio, estabelecer um sistema de comunicação e posteriormente a legitimação de um discurso cultural preponderante.

$\mathrm{Na}$ análise específica do significado do ayllu andino, após o encontro de distintos discursos culturais, foi-lhe atribuída uma acepção compreensível aos dois grupos. A partir do período colonial, o ayllu representava algo distinto do que havia sido em tempos incaicos e na prática converteu-se em estrutura beneficiadora da política colonial espanhola.

\section{Cronistas: uma análise etnográfica andina}

O ayllu, como estrutura básica da organização social andina, foi analisado por historiadores, antropólogos, etnólogos, arqueólogos e outros especialistas, com o intuito de defini-lo e perceber as modificações ocorridas desde a época pré-incaica até os dias atuais. Muitos lançaram mão das crônicas para comprovar suas teorias e consensualmente definiram o ayllu como o sistema de parentesco andino. ${ }^{13}$

A leitura das crônicas quinhentistas propicia aos pesquisadores grande carga informativa, o problema é que, ao interpelarem-nas, alguns incorreram em sérios erros de interpretação, por vezes motivados pelo forte cunho positivista da época (cf. Cunow, 1929a, 1929b,

13 Artigos diversos sobre o ayllu, resultantes de um congresso sobre esse tema, encontram-se em Castelli et al. (1981). Existem vários pesquisadores que abordaram o tema em suas obras, como Mattos Mar (1976), Rowe (1963), Lumbreras (1981), Silverblatt (1990), Zuidema (1991), Wachtel (1973), Godelier (1977), Murra (1983) e Canseco (1988). 
1933; Tudela Valera, 1905; Uhle, 1911; Saavedra, 1913; Eguiguren, 1914; Cuneo Vidal, 1977).

Ao recorrermos às crônicas, temos que estar cientes de que estaremos examinando a representação de um período aos olhos de homens com histórias e objetivos distintos, ou seja, com discursos diversos. ${ }^{14}$ Tais cronistas poderiam ser considerados historiadores que opinaram a respeito do que viram, e cabe a nós perguntar o porquê de assim estarem opinando. Buscar uma definição de ayllu nas crônicas é uma tarefa difícil, pois o que poderemos encontrar não são definições, e, sim, diferentes representações dessa estrutura, que de sistema de parentesco acabou por ser convertida em comunidade no período colonial espanhol.

No século XIX, Heinrich Cunow (1929a) formulou uma proposta a respeito do ayllu andino, relacionando-o com a comunidade de aldeia, acreditando encontrar na marca germânica a explicação para compreender o que os cronistas mencionavam por ayllu. Para fundamentar suas ideias, utilizou erroneamente o livro de Mommsen (1960), em que este aborda o modelo de comunidade romana. Cunow chamava de marca aquilo que Mommsen (1960, p.264) tinha por aldeias familiares, que eram pequenos territórios pertencentes e cultivados por famílias. Partindo dessa premissa, Cunow interpretou o ayllu andino como uma comunidade rodeada de campo de cultivo, tal como foram construídas as reduções no século XVI (cf. Pease, 1981, p.21-2).

Hoje esse tipo de argumento foi superado, pois já se sabe que a comunidade andina que se confundiu com o espaço físico é a redução implantada no período do vice-rei Toledo. O ayllu e a comuni-

14 "Cuando llegaron los españoles, vieron e interpretaron el mundo andino bajo las premisas de la cultura occidental de su tiempo, aplicando los conceptos y modelos europeos a la nueva realidad con la que entraron en contacto. Además, cada autor imprimió a su relato su sensibilidad y apreciación personales. Pero en el fondo la realidad era diferente, las instituciones del mundo andino tenían su propio carácter, su naturaleza sui generis que no pudo ser captada por los observadores europeos en su verdadero significado social" (Silva-Santisteban, 1988, p.147). 
dade não têm relação, pois o ayllu é um sistema de parentesco, e a comunidade, uma organização colonial (cf. Pease, 1978, 1992b).

Alguns pesquisadores, por vezes seguindo uma visão positivista, marxista ou ainda a historicista, tomam como certos os dados das crônicas, que, na verdade, representam a visão dos europeus. O ayllu é identificado por tais cronistas, na maioria das vezes, como um tipo de organização urbana que foi empregada pelos espanhóis nas guerras contra os mouros, em que havia cidades fronteiriças que se baseavam no sistema comunal, exemplos que sobreviveram por largo período na Espanha. ${ }^{15}$ Discutir se o ayllu é um espaço físico antes da conquista espanhola é inviável. Nesse período, essa estrutura é apenas o sistema de parentesco, não existindo comunidade pré-hispânica. A comunidade é tão somente a organização medieval europeia, ${ }^{16}$ que aqui vai se concretizar quando da fundação das reduções toledanas.

O ayllu andino não pode ser inserido num esquema evolucionista, que de sistema de parentesco obrigatoriamente haveria de se transformar em comunidade, até porque a população andina estava dispersa e se movendo continuamente. Para estudar o ayllu pré-hispânico, deve-se partir da análise do sistema de parentesco, visto que este marca a forma como se estabelecem as relações sociais.

Poucos são os dados a esse respeito e os poucos que existem estão nas crônicas, mas nem sempre se pode utilizá-las como fontes verossímeis, já que estas, muitas vezes, são resultantes de um fenômeno ideológico europeu.

Não se encontram evidências reais sequer nas crônicas indígenas. Ayala (1993) não define o ayllu, apenas apresenta as mecânicas de reciprocidade que o justificam.

Não se pode confundir a estrutura social com o espaço físico, pois isso faz parte da estrutura mental do europeu do século XVI. O espanhol também transformou o sistema político dual dos incas em

15 Sobre a sobrevivência de tais comunidades espanholas e a comparação com a comunidade peruana, ver Arguedas (1968).

16 Sobre a comunidade medieval espanhola, ver Cortázar (1990). 
uma monarquia (Duviols, 1980, p.183-96), no entanto nada aparece nas crônicas sobre a dualidade. $\mathrm{O}$ modo que temos para averiguar a existência desse sistema é a explicação dada pelos cronistas para a derrocada do império inca, já que, no momento da conquista espanhola, dois incas disputavam o poder (Portugal, 1995b, p.12). Ao passarem pelo filtro europeu, as informações a respeito do mundo andino são transformadas em categorias do século XVI, em que os espanhóis confeccionam um ideal imperial à luz da história de Roma, visto que esse era o modo como explicavam a própria sociedade. ${ }^{17}$

Nesse período, a Europa fabrica a história do mundo e introduz uma série de categorias que até hoje não estão resolvidas. Um exemplo é a definição da panaca ${ }^{18}$ cuzquenha encontrada nas crônicas, que nada mais é que o modelo do genos ${ }^{19}$ grego.

A utilização de preconceitos ideológicos pode levar à construção de um discurso distorcido. Quando, por exemplo, num sítio arqueológico tenta-se afirmar que uma construção define a organização social, isto só é possível porque se tem uma ideia preconcebida de que, se há uma construção central, essa construção deveria ser do tipo religioso, já que se trata de uma época em que não existia Estado institucional, logo o poder estava em mãos de sacerdotes. Porém, isso faz parte de critérios estabelecidos pela historiografia ocidental, para a qual a organização social é institucional. ${ }^{20}$ Para isso, foi neces-

17 “[...] La España del XVI es una nación mesiánica. La gloria y la riqueza caída tan de improviso sobre sus hombros han llevado a la mayoria al convencimiento de que éste es el pueblo destinado a la gloria. En su glosa a la situación, los escritores de XVI comparan siempre a España con Roma o Israel. Si Roma fue cabeza de la humanidad, Israel era el pueblo selecto, el único que tenía razón frente a sus numerosos enemigos. Como ellos, España tiene obligatoriamente una empresa que llevar a cabo" (Diaz-Plaja, 1988, p.10).

18 Panaca: "miembros de la elite cusqueña" (Canseco, 1988, p.201).

19 "Família extensa aristocrática grega, cujos membros se julgavam descender de um antepassado comum, com freqüência um semideus ou um herói mítico" (Cardoso, 1985, p.85).

20 No que concerne ao ayllu, existe o trabalho arqueológico de Danièle Lavallé e Michèle Julien (1983) que reconstrói a ocupação de um sítio em função do agrupamento familiar. 
sário Evans-Pritchard (1968) mostrar as diferenças entre as sociedades A e B, em que umas estavam organizadas institucionalmente, como é o caso daquelas que formam Estados modernos, e as outras em que a relação de poder se filtra por meio de relações simultâneas, como o parentesco. São as relações de parentesco que estruturam essas sociedades. Quase toda a sociedade do mundo funcionava dentro desse sistema e não do sistema institucional, representado pelo Estado moderno.

O mundo medieval antes de ser institucional também era baseado na estrutura de parentesco. O livro de Le Roy Ladurie (1986) retrata um fenômeno ocorrido no sul da França, que é afetada por um conflito devido a um processo de extirpação de idolatrias. Interessante é que nessa obra está clara a importância do sistema de parentesco na organização dessa sociedade proveniente de uma realidade herética em depressão.

De acordo com os exemplos apresentados, é necessário definir os objetivos da pesquisa a ser realizada e não utilizar conceitos preestabelecidos. Partindo desse pressuposto, no caso das crônicas espanholas, sabemos que estas foram escritas por homens imbuídos de preconceitos etnocêntricos. Sendo assim, trabalharemos com a representação do ayllu à luz de categorias externas à realidade andina. Para trabalhar os cronistas, é necessário sutileza e, sobretudo, aprender a ler de novo.

Para aqueles que têm a intenção de compreender o ayllu, faz-se necessário contrastar informações etnográficas com as de cronistas e com a informação moderna que se tem sobre o ayllu. Como o intuito de nosso trabalho é perceber as diversas representações dadas ao ayllu em documentos e crônicas de espanhóis e indígenas em momentos históricos distintos, não necessitaremos recorrer a esse método, visto não almejarmos uma definição do ayllu, e sim o manancial de cambiantes originados nessa confluência de discursos. 


\section{Aportes historiográficos}

A partir do final do século XVI, o vocábulo ayllu deixa de corresponder à antiga realidade indígena, passando a configurar uma estrutura pertencente ao sistema colonial espanhol. O estudo das várias representações do ayllu até sua conversão em comunidade permite perceber o pensamento desse homem do século XVI, que descreve o que lhe é alheio conforme seus próprios conceitos ou mesclando realidades, o que é mais usual em crônicas indígenas.

Para tanto, é necessário saber primordialmente quais as fontes utilizadas por tais cronistas para realizarem seus escritos. A maioria dos cronistas espanhóis, que começaram a preocupar-se em descrever o império inca, coletou suas informações junto aos representantes da aristocracia cuzquenha, e outros, de curacas (chefes locais) ou ainda dos descendentes de Atahualpa, o Inca de Quito. Essa visão "oficial" dos cuzquenhos, confrontada com a dos outros informantes, provocou inúmeras distorções que podem ser comprovadas analisando-se e comparando-se a produção literária pós-conquista (Bernand, 1994, p.70).

As primeiras obras consideradas científicas que utilizaram as crônicas como fontes começaram a surgir no final do século XVIII. Ao contrário de Marmontel (1991), que escreveu sobre os incas sem nenhuma base documental, o abade Raynal (1820) imprimiu sua Histoire philosophique em 1770, em que fez uma crítica da história incaica baseando-se nas fontes. O historiador William Robertson (1777) conseguiu chegar a conclusões razoáveis sobre o império inca, consultando as crônicas, mesmo tendo sido absolutamente influenciado por Garcilaso, tornando-se, conforme expõe Ake Wedin (1966, p.8), um seguidor da tendência pró-incaica. Contrariando essa postura, o holandês Corneille de Pauw (1768-1769) descarta as informações de Garcilaso, trocando-as pelas de Zárate e outros cronistas contrários aos incas.

Os primeiros aportes diferenciados de pesquisa a respeito dos incas foram feitos por Prescott (1862), que buscou fontes até então desconhecidas para basear seus estudos. O espanhol Jiménez de la 
Espada $(1877,1892)$ também contribuiu para esse avanço historiográfico, sendo o responsável pela impressão de diversos manuscritos inéditos.

Existem alguns estudos historiográficos importantes que traçaram uma classificação das crônicas peruanas, avaliando-as de acordo com distintos critérios. Clements Markham (1910) selecionouos conforme a raça e a profissão, diferenciando os cronistas indígenas dos espanhóis e subdividindo estes últimos em cronistas-soldados, geógrafos, jurídicos e religiosos. Riva-Agüero y Osma (1910) os classificou em espanhóis, índios e mestiços, porém apenas se ocupou dos cronistas nascidos no Peru. Alvo de severas críticas, inclusive por parte de Riva-Agüero y Osma, foi o critério utilizado por Means (1931) ao dividir as crônicas em duas escolas, a garcilasista e a toledana, ou seja, baseando-se na opinião sustentada por cada cronista perante o incário. Essa divisão também foi criticada por Rowe (1963) e, posteriormente, por Wedin (1966).

Em distintos estudos, Louis Baudin (1945) e Porras Barrenechea (1973) introduziram um esquema em que relacionaram os cronistas e suas obras de modo a facilitar a sua utilização. Essa classificação tinha o intuito de compreender todo o processo histórico da conquista e sua evolução, seguindo uma pauta cronológica em conformidade com os feitos. ${ }^{21} \mathrm{O}$ problema desse esquema é que se torna difícil encaixar os cronistas nessa compartimentalização, visto que facilmente resvalam de um setor a outro (Pease, 1978).

AkeWedin (1966) chamou a atenção sobre esse aspecto e propôs classificar os cronistas de acordo com a proximidade temporal em relação à memória oral, ou seja, para ele os cronistas da conquista, inevitavelmente, teriam tido mais acesso às informações do que aque-

21 Para Louis Baudin (1945), a divisão lógica era propiciada pela diferenciação profissional e cronológica, ou seja, cronistas que conheceram o império inca, os que chegaram depois da destruição deste e aqueles que não estiveram no Peru, mas recolheram os dados dos primeiros conquistadores. Para Barrenechea (1986), a divisão deve ser feita em incário, descobrimento, conquista, guerras civis da conquista e cronistas pré-toledanos, toledanos e pós-toledanos. 
les que chegaram ao Peru no período colonial. ${ }^{22}$ Sabemos que esse tipo de análise possui suas incoerências, visto que a fonte oral aludida por Wedin era a visão "oficial" dos cuzquenhos ou até mesmo de chefes locais inimigos dos incas, o que pode ter gerado uma série de informações incongruentes.

Nosso objetivo não é realizar um esquema classificatório das crônicas peruanas, mas apenas compreender que não é possível buscar informações concretas a respeito do mundo andino, mas, sim, imagens produzidas por diferentes membros de uma sociedade hispano-americana. Analisar as crônicas quinhentistas nos proporciona uma gama infindável de representações, das quais podemos filtrar dados inerentes a um determinado período e que, sob a influência de fenômenos sociais, podem ter sido modificados.

\section{Crônicas que espelham o ayllu}

Sabemos que o ayllu passou por transformações conceituais e concretas desde o período em que correspondia à realidade indígena até a sua assimilação no período colonial. Para conseguirmos estabelecer um diálogo com as crônicas quinhentistas, temos de selecionar aquelas que melhor correspondem à problematização enfocada.

Os cronistas do período da conquista foram aqueles que coletaram seus dados junto aos quipo-camayoc, homens que eram responsáveis, entre outras coisas, por conservar a história incaica. Porém, essa é a chamada tradição "oficial”, da qual absorveram seus dados Cieza de León (1991), Cabello Valboa (1951) e Martín de Múrua (1986), por exemplo. Outros recolheram suas informações junto a chefes de diferentes localidades que lhes contavam suas memórias pessoais, sendo esse o material que originou as Relaciones geográfi-

22 "Esto significa, en resumidas cuentas, que mientras más temprana sea una crónica, tanto mejos sus bases. Esto supone como consecuencia que una simple agrupación de las crónicas en ordem cronológico, según el año de redacción o impresión, es la más útil desde el punto de vista metódico" (Wedin, 1966, p.40-1). 
cas de Indias (La Espada, 1965) e que também foi utilizado por Sarmiento de Gamboa (1988) e Francisco de Toledo (1940a, 1940b).

As primeiras crônicas que tratam da história do Peru quase não mencionam o ayllu, pois os soldados, aventureiros e até mesmo religiosos estavam mais preocupados com suas façanhas, e menos em compreender esse "outro" que urgia conquistar. Na verdade, o importante era saber quantos índios havia em determinado local e qual a extensão de terra disponível a ser repartida entre os conquistadores.

O período de maior interesse para a realização de uma investigação a respeito do ayllu no século XVI abarca os primeiros anos de conquista até a década de 1580, que é quando se modificam os critérios de análise do incário e quando ocorrem as grandes mudanças coloniais, representadas pela implantação das reduções toledanas. Partindo desse postulado metodológico, é possível vislumbrar as principais representações conferidas a essa estrutura de parentesco andina, utilizando para tal crônicas e documentos de períodos distintos, quando assim aprouver e for justificável.

O cronista Cieza de León é fundamental para a compreensão do ayllu, mesmo sendo um soldado que vivenciou o período inicial da conquista, e, como se sabe, eram raros aqueles que dominavam a língua quechua. Ele, diferentemente de seus companheiros, tinha uma curiosidade aguçada e sagaz e soube captar a realidade andina, transpondo esses limites linguísticos.

Juan de Betanzos (1968) equipara-se em valor etnográfico a Cieza de León, pois, além de haver se casado com a irmã de Atahualpa, transformou-se no intérprete oficial de Pizarro, visto ter se dedicado desde cedo ao estudo do quechua.

A obra de Juan de Matienzo (1967)é de grande importância para apreendermos o momento histórico em que o ayllu se transforma em um espaço territorial, pois esse cronista foi o mentor das reduções toledanas. De cunho jurídico, esse tipo de crônica representou o discurso de legitimação do poder espanhol sobre o povo inca. Matienzo, Francisco de Toledo e Sarmiento de Gamboa representam a tendência anti-incaica em suas crônicas, apresentando os incas não como um povo primitivo, mas como um povo de perfeita orga- 
nização e que subjugava o restante da população de forma tirânica; por isso, era legítimo o poder espanhol sobre os incas, pois libertara as populações andinas "escravizadas" por estes. Já os cronistas que apoiavam o incário enalteciam essa organização com o intuito de provar o alto nível cultural e político desse povo. Tanto as fontes a favor dos incas como as contrárias estavam de acordo quanto à excelente organização incaica (Wedin, 1966, p.77).

Polo de Ondegardo (1990), apesar de não ter sido um cronista que tenha produzido uma obra importante para a análise do mundo incaico, foi representativo para o período colonial. Ele foi um opositor da perpetuação do sistema de encomienda, visto ser uma injustiça os espanhóis apoderarem-se inclusive das terras que outrora pertenciam ao povo, pois nem os incas usurparam da população o direito à terra. A parte que cabia ao Inca e ao Sol era plantada coletivamente, e a restante pertencia ao ayllu e era administrada pela autoridade local com fins tributários e de subsistência. Os espanhóis, ao instalarem a encomienda, não satisfeitos de se apoderarem da totalidade territorial, também incutiram à população indígena uma nova forma de tributação.

Obras menores, como as de Cristóbal de Molina (1959) e Francisco Falcon (1867), também merecem atenção por parte do pesquisador, visto que são compostas de materiais coletados por seus autores junto ao povo andino.

A crônica de José de Acosta (1954) deve ser analisada tão somente para perceber a visão de um religioso sobre o mundo indígena, pois, apesar de sua conhecida importância para os estudos dos povos pré-colombianos, quando se refere ao Peru, utiliza as informações de Ondegardo, já que a transcrição era uma prática corriqueira na época.

Com o intuito de contrapor distintas representações do ayllu, faz-se necessário o estudo não somente das obras redigidas pelos espanhóis, mas também de indígenas e mestiços. Existem poucas fontes, mas de fundamental importância para compreensão dessa estrutura andina. Sabemos que esses cronistas mesclaram critérios europeus e indígenas, e alguns também recolheram seus dados junto aos nobres de Cuzco, como foi o caso de Garcilaso de la Vega (1991). Mes- 
tiço, filho de um conquistador espanhol e de uma princesa inca, passou sua infância no Peru, mas logo foi para a Espanha, onde estudou e redigiu sua crônica. Seu discurso é adaptado ao público espanhol e por isso mesmo chega a negar a existência de sacrifícios humanos entre os incas, visto ser algo repulsivo à mente europeia.

Joan Santa Cruz Pachacuti (1993), Guaman Poma de Ayala (1993) e Titu Cusi Yupanqui (1992) são índios que basearam suas crônicas nos relatos heroicos dos cuzquenhos e simbolizaram o resultado da aculturação sofrida por esse povo. Pachacuti, profundamente cristianizado, fez de sua crônica um catecismo, utilizando conceitos teológicos para explicar o mundo andino desde sua origem (Portugal, 1995b, p.78). Guaman Poma de Ayala e Titu Cusi representam a oposição ao mundo colonial com seus escritos apologéticos e cheios de contradições, fato plausível, já que eram homens andinos que haviam sido educados e cristianizados pelos espanhóis.

As crônicas que tratam do período colonial inicial até a implantação das reduções de Toledo são as que podem nos fornecer as melhores representações do ayllu incaico e colonial.

Antes da chegada dos espanhóis, o ayllu simbolizava o sistema de parentesco e, ao ser representado por diferentes cronistas, de conceito territorial abstrato foi transformado em comunidade, conforme os moldes europeus de aldeia detentora de um espaço territorial demarcado. A confluência de discursos que representavam o mundo indígena propiciou o surgimento dessa nova concepção de ayllu.

Os cronistas abordaram a história dos incas de distintas formas: uns assumiram uma postura contrária e denegriram a imagem desse povo, e outros procuraram compreender e valorizar essa cultura. Espanhóis e indígenas, muito embora representantes de culturas diferentes, articularam discursos verossimilhantes por causa da aculturação sofrida por estes.

A construção discursiva do ayllu começou por ser engendrada desde que os cronistas se apropriaram de seu significante, que de signo representativo de uma simbologia indígena foi transformado em modelo de comunidade aldeã do medievo europeu. As crônicas 
não nos fornecem dados sobre o significado do ayllu propriamente dito, mas, sim, a imagem que esses homens do século XVI forjaram de acordo com as fontes utilizadas e objetivos pessoais.

Diante da dificuldade em definir essa estrutura indígena por meio da complexa documentação de que dispomos, é de grande valia pesquisar a representação dela com o intuito de perceber esse entrelaçamento de ideias alusivas a culturas distintas. Essa conjugação de estereótipos culturais europeus e indígenas refletida em discursos permitiu que o ayllu colonial assumisse uma nova conotação, que, em razão também das mudanças socioeconômicas da época, consolidou-se na prática. O ayllu colonial configurou-se nessa fronteira discursiva, em que cronistas espanhóis e indígenas traduziram em palavras as práticas culturais inerentes à realidade do encontro/desencontro desses povos. 


\section{2 \\ ESPANHA NO TEMPO DA AMÉRICA IMAGINÁRIA}

Para compreendermos as diferentes representações do ayllu andino nas crônicas quinhentistas, necessitamos conhecer as raízes culturais dos europeus que arribaram em terras americanas. Para tanto, precisamos ter em conta que a Espanha do século XV era marcada por traços do medievo europeu e ao mesmo tempo estava à beira de renovações econômicas, culturais e políticas, que se fariam sentir nos séculos posteriores.

\section{O medievo europeu}

Na Europa dos séculos XI a XIII, houve grande desenvolvimento agrícola e comercial, pois a produção de cereais cresceu, ocasionando um aumento de mercados e feiras e também a ampliação da circulação monetária. No século XII, surgiram as primeiras cidades que atingiram seu auge durante o século XIII. O crescimento populacional em demasia provocou uma crise alimentar, pois os produtos agrícolas não eram suficientes para abastecer todas as regiões, provocando a busca por tais produtos em outros mercados, a preço mais alto.

Nos séculos XIV e XV, instalou-se a crise do modo de produção feudal, pois os períodos de fome (1315-1317 e 1346-1347) acarreta- 
ram sucessivas doenças. A peste negra (1347-1351) e as guerras que ocorreram nesse período, como a dos Cem Anos (1337-1453), provocaram a diminuição populacional na Europa (Monteiro, 1987, p.74).

Essa crise gerou a necessidade de expansionismo, levando à busca de novas terras e novos mercados que atendessem à demanda das cidades e do comércio. Com os descobrimentos do século XV, ocorreu uma grande transformação nas concepções de tempo e espaço, pois apareceu o relógio, que serviu para controlar todas as atividades cotidianas. No início, ele despertou desconfiança e ninguém queria se submeter a uma máquina, pois a luz e os sinos dividiam muito sabiamente o dia e a noite (Silva, 1991, p.46).

Durante a Idade Média, ninguém se preocupava em medir o tempo, pois isso cabia a Deus. O homem desse período explicava os acontecimentos cotidianos como desígnios divinos. Com o surgimento dos mercadores, passou-se a necessitar de um controle do tempo e também do espaço, pois, conforme a distância a que ficassem os mercados, mais tempo se perderia e o objeto mercantil, o lucro, diminuiria.

Jacques Le Goff (1980), ao analisar a concepção de tempo na Idade Média, fez uma diferenciação entre o "tempo da Igreja", regido pelo sino e pela oração, e o "tempo do mercador", que tinha o relógio para sua orientação. Gerou-se, nesse período, um conflito entre a Igreja e os mercadores, pois esta acusava os mercadores de utilizar o tempo como objeto de lucro, e, no entanto, segundo a Igreja, o tempo pertencia a Deus. ${ }^{1}$

O conhecimento do espaço físico, geográfico e cartográfico foi de grande valia para facilitar as navegações a locais distantes, pois, tendo o controle da distância a ser percorrida, os navegadores po-

1 "O conflito entre o tempo da Igreja e o tempo dos mercadores afirma-se em plena Idade Média, como um dos acontecimentos maiores da história mental destes séculos, durante os quais se elabora a ideologia do mundo moderno, sob a pressão da alteração das estruturas e das práticas econômicas" (Le Goff, 1980, p.45). 
diam calcular o tempo necessário para realizar a viagem e, consequentemente, saber a quantidade de produtos necessários para o abastecimento da tripulação.

Esse período foi marcado pelas grandes viagens, e seus relatos propagaram-se por toda a Europa graças ao aparecimento da imprensa, fazendo que o homem dessa época passasse a sonhar com as maravilhas encontradas em outras partes do mundo.

As principais características dos navegadores dessa época eram a honra, a religiosidade, o fascínio por novidades, bem como o espírito de guerreiro, conquistador e herói. Esses homens estavam a serviço de Deus e de seu rei, e, por isso, seus espíritos aguerridos eram insuflados pela fé que os movia.

Nesse período, o tempo ainda era "controlado por Deus", ou seja, não importava quanto tempo se levaria numa viagem dessas, pois tudo era demarcado pela extensão do percurso. Por vezes, tais aventureiros nem sequer sabiam se algum dia retornariam às suas cidades, a curiosidade os levava para longe, o anseio por libertar-se do mundo feudal, a busca do romance cavaleiresco, do exuberante, isso bastava para que saíssem mar afora.

Eram homens de extrema coragem, pois nesse período não se buscava o "paraíso" sem temer o que poderia acontecer. ${ }^{2}$ Uma extraordinária força de vontade movia os descobridores renascentistas. Para uns, o mar representava um desafio; para outros, o medo. Mesmo assim, um grande número de aventureiros cruzou os mares, apesar da forte crença que os acompanhava de que o mar era o lugar de medo, da morte e da demência, onde habitavam demônios e monstros, e essa ideia não se modificou até as vitórias da técnica moderna (Delumeau, 1989, p.50-1).

2 "No final da Idade Média, o homem do Ocidente continua prevenido contra o mar não apenas pela sabedoria dos provérbios, mas também por duas advertências paralelas: uma expressa pelo discurso poético, a outra pelos relatos de viagens [...]" (Delumeau, 1989, p.42). 
Por trás dessas crenças legendárias ou desses exageros assustadores, adivinha-se o medo do outro, isto é, de tudo que pertence a um universo diferente. Por certo, os aspectos extraordinários que eram atribuídos aos países distantes podiam também constituir um atrativo poderoso. A imaginação coletiva da Europa na Idade Média e na Renascença inventava, para além dos mares luxuriantes e luxuriosos, paraísos cujas miragens arrancaram para fora dos horizontes familiares descobridores e aventureiros. O distante - o outro - foi também um ímã que permitiu à Europa sair de si mesma [...] (ibidem, p.54)

Os movimentos considerados inauguradores da Idade Moderna - o Renascimento, o protestantismo, os descobrimentos e a centralização - são medievais. Conforme as afirmações de Hilário Franco Júnior (1992), o primeiro buscou os modelos culturais clássicos já conhecidos na Idade Média. O protestantismo não passou de uma heresia que deu certo. Os descobrimentos também tinham suas bases medievais nas técnicas náuticas (construção naval, bússola, astrolábio, mapas), na motivação (trigo, ouro, evangelização) e nas metas (Índias, Reino de Preste João). Colombo, por exemplo, é considerado pelo autor um homem medieval, pois tinha por objetivo a difusão do cristianismo, acima da busca do ouro. Apenas necessitava dele para realizar uma cruzada a Jerusalém. Queria chegar ao Oriente, pois para ele era lá que estava o paraíso terrestre. A centralização política era a conclusão de um objetivo perseguido por monarcas medievais (ibidem, p.170-2). O homem do Renascimento tinha muitas características medievais, como acabamos de analisar, porém foi nesse período que surgiram as utopias que retratam o anseio por uma sociedade diferente.

As Utopias da Renascença, por ex. Thomas Morus, a ilha Utopia, Campanella, a Cidade do Sol, ou a de Bacon, Nova Atlântida, deixam bem claro a influência de novas idéias filosóficas que estão surgindo, o aparecimento do Estado nacional e o descobrimento de novos mundos. A tudo isso, poder-se-á acrescentar que o aparecimento de uma nova consciência social teria sido impossível sem o insurgimento dos camponeses e burgueses contra o feudalismo. Face à nova forma de expressão 
de utopias, tais como o gênero literário da sátira, descrição de fantásticas viagens por outros recantos do mundo, como uma forma de expressar os projetos críticos de uma nova sociedade. (Sidekum, 1993, p.21)

Essas aspirações do homem renascentista de encontrar um paraíso terrestre impulsionaram cada vez mais os descobrimentos. $\mathrm{O}$ homem se voltou para o mar, a cidade tornou-se, acima de tudo, uma poderosa máquina econômica inteiramente voltada para o mar, e o século XV transformou-se no "século do mar" (Attali, 1991, p.64, 70).

A importância de encontrarem-se novas terras cresceu, e os mercadores foram expandindo seus negócios. Nesse período, imaginava-se o mundo tripartido, mas surge uma quarta parte, a América. Quando Colombo aporta em 1492 em terras americanas, gera-se uma grande mudança mental e econômica na Europa.

Antes de ser descoberta, segundo Edmundo O'Gorman (1992), a América já havia sido inventada, pois há muito os europeus aspiravam por um local onde pudessem concretizar seus planos, como comprovam as utopias da Renascença.

O mercantilismo, "conjunto de idéias, seguido de uma prática política e econômica desenvolvida pelos Estados europeus na Época Moderna" (Prodanov, 1990, p.14), é amplamente difundido com o descobrimento. Não queremos afirmar com isso que o descobrimento da América se deu por motivos puramente econômicos. Os mercadores financiaram a realização dessa empresa e tinham por objetivo conseguir ouro e outras riquezas, mas, por trás do interesse econômico, estava uma grande mudança de mentalidade. Como apresenta Janice Theodoro da Silva (1987, p.13), os "descobrimentos representavam uma grande oportunidade para os povos ibéricos concretizarem seus sonhos, construindo, reproduzindo e assimilando na América todo o processo cultural de que eram originários".

Segundo Elliot (1987, p.193), foi a escassez de metais preciosos na Europa de fins do século XV que impulsionou as aventuras coloniais, e os conquistadores foram recompensados, pois já nos primeiros anos haviam encontrado ouro nas Antilhas. 
Existem diferentes teorias sobre os motivos que levaram os europeus a se aventurar pelo mar em busca de novas terras: uns apontam o fator econômico como principal força motriz, e outros, a mudança da mentalidade europeia, que via nos descobrimentos uma forma de realizar suas aspirações de ascensão social, de enriquecer e viver mais dignamente.

\section{As comunidades camponesas nos reinos de Fernando e Isabel}

Depois de apresentarmos um panorama da situação europeia na Idade Média e início dos tempos modernos, faremos uma incursão pela história da Espanha para entender as concepções tidas pelos cronistas que descreveram o mundo andino. Como no capítulo anterior mostramos que era natural no processo de alteridade a utilização de conceitos familiares para explicar algo alheio, faz-se necessária agora a compreensão da ideia de comunidade tida por espanhóis, já que, por vezes, foi esta a que empregaram na representação do ayllu. Sabemos ainda que o ayllu colonial está representado numa confluência de discursos, portanto não descartamos o posicionamento indígena nem de espanhóis, que sabiam quechua e conseguiram apreender esse mundo. De qualquer maneira, de acordo com a história colonial peruana, o ayllu acabou sendo resultado das práticas culturais legitimadoras da preponderância espanhola e também dos distintos discursos propagados pelos cronistas.

Entender a concepção de comunidade rural nos reinos espanhóis durante a Idade Média é uma tarefa árdua, por causa da diversidade de regiões existentes sob o controle de distintas coroas e da quantidade de temas a abordar. Em razão disso, é necessário nos reportarmos ao final da Idade Antiga para delinear uma conjuntura histórica, que nos aclare sucintamente que tipo de comunidade pode ser encontrada no medievo espanhol. Por causa da dificuldade apresentada, trataremos a comunidade de forma sucinta e genérica, não nos aprofundando em conjecturas de concei- 
tualização regional, pontuando apenas com alguns exemplos, quando necessário.

\section{O processo econômico de ruralização no Baixo Império Romano}

Durante o século III, o Império Romano vivia uma crise que afetou o âmbito econômico, cultural, político e militar da sociedade. Por ser a civilização romana sedimentada no bom funcionamento da cidade, como centro de decisões não só políticas, mas também econômicas, com a crise geral durante o Baixo Império, essas cidades entraram em decadência. Com a debilidade da urbe, ocorreu o fenômeno de ruralização e a economia agrária passou a prevalecer.

Essa mudança radical no sistema econômico do Império leva a modificações populacionais, pois o povo que vivia na cidade se transfere em massa para o campo. Desse modo, as transformações ocorrem com a estrutura de propriedade e também nos sistemas de produção, afetando o grupo de camponeses de tal forma que dessa realidade se originará o estereótipo de camponês medieval.

Como a agricultura foi uma importante fonte de renda para o Estado romano, nada mais coerente do que o aparecimento de uma série de leis destinadas a facilitar o acesso à terra, que, obviamente, tinham também a finalidade de conseguir uma maior produtividade e um aumento de impostos recolhidos. Essa política se deu graças à abundância de terras incultas - saltus - em relação às que eram produzidas - ager. Assim, era possível lograr um terreno inculto pelo simples fato de se passar a cultivá-lo, adquirindo o chamado possessio, que era o direito de usufruto sobre essa terra para sempre, mesmo quando tal área tivesse um dono. Também era possível adquirir a propriedade plena, proprietas, desde que se cultivasse essa terra por mais de trinta anos. Essas facilidades poderiam ter proporcionado o surgimento de uma grande quantidade de pequenas e médias propriedades, mas essa política estatal não obteve êxito, pois acabou por beneficiar a aquisição maciça de terras por parte dos grandes latifun- 
diários, que, com o desaparecimento do mundo comercial e artesanal, passaram a investir em terra. $\mathrm{O}$ mundo rural dessa época apresenta uma grande concentração de terras e a necessidade de muita mão de obra. Foi quando o sistema produtivo clássico romano, o escravismo, começou a ser substituído paulatinamente pela mão de obra de colonos. Os escravos apresentavam baixa produção porque não tinham motivos para se dedicar a uma tarefa da qual não tiravam nenhum proveito. Era cada vez mais escasso o número de escravos por causa da falta de guerras, que propiciavam a renovação do número de pessoas necessárias à agricultura, e também porque a população não podia mais ser escravizada em virtude de dívidas. Dessa forma, o número de escravos disponíveis era insuficiente para atender à demanda da ruralização. O estatuto do escravo passou por modificações, o que melhorou sua situação, a partir do momento em que este podia se converter em um agricultor permanente de uma terra, terminando com a economia escravista clássica, pois seu sistema produtivo não se baseava só nesse grupo (Fernández, 1999, p.9-18).

\section{O patronato e o futuro aparecimento da behetría em Castela}

Com o declínio da escravidão no Baixo Império, outro grupo camponês foi afetado, o dos colonos que eram livres, mas sujeitos à tributação e ao recrutamento militar por parte do Estado. Esse grupo também não tinha grandes direitos, e, com a crise geral, sua situação se agravou, pois, por qualquer motivo, esses colonos ficavam endividados e eram obrigados a se converter em serviçais de grandes proprietários. É nesse momento que surge uma nova instituição, o patronato. Por meio dela, os colonos tornam-se dependentes da proteção de grandes senhores de terra que os defendam da opressão fiscal e militar do Estado. Os proprietários de terra lucram com esse sistema, pois podem exercer um controle sobre um maior número de homens para a produção e, muitas vezes, conseguem adquirir novas propriedades, já que os pequenos colonos que se submetiam à 
sua proteção vendiam seu pedaço de terra ao senhor, e, na maioria das vezes, essa venda era fictícia.

Esse sistema causou o aparecimento de uma economia paralela que escapava ao controle do Estado e que só beneficiava os grandes proprietários, que não mais pagavam impostos e cada vez contavam com mais mão de obra. Passaram a contar, inclusive, com um exército particular para defendê-los contra as pretensões das autoridades imperiais. O resultado desse processo foi a diminuição das classes médias camponesas e a divisão social e econômica em dois grupos: poderosos e camponeses.

Com as grandes invasões do século $\mathrm{V}$, que não causaram grandes danos na zona rural, houve um processo de assimilação entre romanos e germanos, que passaram a compartilhar o espaço econômico, fazendo surgir dois modelos de produção agrícola. O modelo romano era basicamente dedicado à produção agrária em um espaço disperso e o germânico tinha como característica a presença do bosque e do povoamento em aldeias com economia essencialmente agropecuária. O modelo germânico de propriedade familiar se contrapôs à antiga propriedade individual tipicamente romana. Mesmo assim, eram duas sociedades agrárias, uma pela origem e outra pela degradação da economia urbana, e as duas desenvolveram instituições sociais semelhantes que intensificavam a dependência pessoal, e, assim, o sistema de patronato romano se aliou ao de clientela germânico.

Os membros das comunidades de aldeia surgidas nesse período usufruíam coletivamente do uso de moinhos, da água, zonas de pesca, e não se conhece ao certo o tipo de vínculo de parentesco que mantinham entre si. Sua característica, sem dúvida, era a vida comunal, e há indícios de que essas comunidades eram compostas por famílias extensas, com filiação patriarcal, mas não raro apareciam também grupos matriarcais. Havia uma tendência maior a uma segmentação de linhagens e à difusão da família conjugal. Sabe-se, no entanto, que essas comunidades permitiam em seu seio a presença de indivíduos oriundos de outras comunidades, os quais poderiam ser simples colonos ou ter ingressado nessa comunidade por meio 
do matrimônio. Para além da importância do parentesco na formação dessas comunidades, o território era fundamental para a manutenção desse grupo e era composto pela aldeia propriamente dita e por terras agrícolas, zonas de pastos e, em certas ocasiões, bens próprios, como a igreja (Pastor, 1984, p.94-103).

Durante os séculos V, VI e VII, esse mundo rural resultante da mescla de traços romanos e germânicos foi evoluindo e causou o surgimento de novos tipos de proprietários, como a Igreja e a realeza, mas a estrutura de propriedade se manteve intacta. A produção da terra seguiu a fórmula usada nas villas romanas, ou seja, o uso de mão de obra por estações ou a cessão de pequenos lotes de terra a camponeses para que os cultivassem. Essa realidade fez que a situação dos camponeses piorasse cada vez mais, pois estavam subjugados pelos grandes proprietários de terras. Durante o Baixo Império, por causa da instituição do patronato, tais homens foram obrigados a tentar escapar das pressões do Estado convertendo-se em serviçais, porém, depois das invasões e com o desaparecimento do patronato, desapareceu também o conceito de cidadão, pois os camponeses se encontravam numa situação de extrema insegurança, não podiam contar com uma instituição política que os defendesse, opressora que fosse, e caíam em uma irremediável dependência pessoal.

Nesse contexto, surge uma nova instituição, a encomendación, que era uma forma jurídica em que o camponês desamparado se colocava sob proteção de um grande proprietário de terra, e, em troca, este senhor lhe entregava um lote de terra para seu usufruto. Essa instituição nada mais é que uma junção das tradições romana e germânica, ou seja, do patronato e da clientela. Esses homens juridicamente eram livres, pois, na verdade, a encomendación não passava de uma solicitação de proteção pessoal.

No reino de Castela, durante a Alta Idade Média, a encomendación adquiriu características singulares, e a entrada nesse tipo de dependência se deu em melhores condições do que para o resto dos camponeses europeus. Ocorreu a chamada encomendación de benefactoría (de bene facere $=$ fazer bem), que mais tarde será conhecida como behetría. A principal característica dessa instituição era a liberdade 
de movimento que tinha o encomendado, que podia romper o vínculo pessoal em qualquer momento e escolher um novo senhor. Os camponeses que procuravam a proteção dos grandes senhores entregavam a estes todos ou parte de seus bens, mas não necessariamente perdiam sua liberdade. Ao longo dos séculos XI, XII e XIII, a situação desses homens e aldeias foi se modificando, já não era tão fácil eleger o próprio senhor. Os camponeses que detinham o domínio sobre a maior parte das terras da localidade podiam eleger o seu senhor, que obrigatoriamente tinha de ser fidalgo, com grande poder e possuir ou não terras na região, o que, às vezes, era difícil de acontecer. Assim apareceram as behetrías de mar a mar, entre parentes e de linhagens.

Esse processo gerou, já no século XIV, uma patrimonialização da behetría em poder de algumas linhagens da nobreza. O ordenamento de Alcalá de 1348 proibiu legalmente que homens de behetrías alienassem suas propriedades ao poder de gente que não estivesse submetida às mesmas obrigações locais, o que representava para os camponeses a perda da propriedade real da terra. Desde então, um só senhor podia controlar toda a aldeia de behetría. Depois de alguns conflitos, a condição dos homens de behetrías foi equiparada à de vassalo solariego (Artola, 1991, p.143), ou seja, esses homens ficaram subordinados ao poder de um só senhor, para o qual deveriam prestar serviços. Apesar disso, os homens de behetría continuaram tendo liberdade jurídica.

Durante o período inicial do feudalismo, prevalecem as pequenas e médias propriedades de grupos que lutam para escapar de uma possível dependência em relação aos grandes. Fossier (1996) provou que havia propriedades em mãos de homens livres, o que mostra uma resistência desse camponês ante a dominante grande propriedade. As difíceis condições de vida desses homens tornavam quase impossível resistir à pressão econômica e social exercida por nobres e religiosos locais, que utilizavam sua influência para submeter os pequenos proprietários ao seu controle.

Pelo exposto até aqui, o grupo que prevalecia era composto pelos pequenos camponeses que trabalhavam em terras que não lhes per- 
tenciam, que recebiam o nome de mansos, ou seja, parcelas de terra das quais usufruíam. No entanto, esses camponeses continuavam dependentes do proprietário da terra. Essas parcelas, originariamente, haviam sido lotes de terra capazes de alimentar uma família, mas logo foram convertidas em fonte de rendas para os grandes senhores. O usufruto do manso acarretava também a obrigação de proporcionar ao senhor mão de obra (corveias), em que todos os membros deveriam prestar serviços ao seu senhor. ${ }^{3}$

Dentro dos mansos podiam ser encontrados colonos denominados escravos ou servos, porém o escravo, nesse caso, não tem a conotação clássica, mas um caráter de dependência distinto do servo, visto que o escravo não possui nenhum direito jurídico.

A desaparição da noção de Estado deixou o indivíduo mergulhado em um mundo de inseguranças, o que o levou a procurar novos marcos de relação social que pudessem proporcionar alguma segurança. Temos então a família, as relações de dependência com o senhor e a aldeia.

A família dessa época é um grupo extenso que conjuga seus interesses e se ajuda mutuamente. O patrimônio é coletivo e todos habitam no mesmo local, sendo os laços familiares muito fortes, e como prova temos o costume da vingança de sangue, que leva todo o clã a perseguir e castigar aquele que tenha de alguma forma causado dano a algum membro da família. ${ }^{4}$ Porém, num mundo cheio de violência, a família não é o suficiente para proporcionar segurança, faz-se necessário então recorrer à proteção de um poderoso, visto que o conceito de Estado se perdeu.

O outro marco de relação social fundamental junto à família seria a comunidade aldeã. De difícil definição, por serem de origens

3 O manso se assemelha ao tupu dos incas, que era também o lote de terra distribuído a cada família anualmente para sua subsistência. Em troca disso, o hatun runa (homem comum) passava a ter uma série de obrigações em relação não a um senhor, mas ao Estado, pois tinha que pagar tributo em espécie (alimentos) ou em trabalho.

4 "O primeiro dever de um membro de uma linhagem era a vingança" (Bloch, 1982, p.254). 
romana ou germânica e com funções distintas, não se pode afirmar que tipos de comunidade existiram. Entretanto, se partirmos do pressuposto de que só poderiam existir comunidades de aldeia quando o grupo camponês possuísse uma organização interna, uma personalidade jurídica e a consciência de fazer parte de uma comunidade que tivesse capacidade de organizar seu território, verificamos que nessa época não existiu comunidade de aldeia como marco de relação. Uma das características da época é exatamente a itinerância dos núcleos de povoamento, ou seja, era difícil haver um enraizamento permanente de povoamento em núcleos mais ou menos concentrados. Com os avanços no setor agrícola, apareceram os mercados que deram origem às futuras aldeias medievais. Por volta dos séculos X e XI, começaram a aparecer as aldeias com a ajuda de grandes senhores, que viram nisso a possibilidade de controlar os camponeses.

Entre os séculos XI e XIII, o Ocidente cristão viveu a etapa de maior esplendor de todo o medievo, período em que se consolidou o sistema feudal. A população europeia aumentou consideravelmente nesses séculos, havendo consequentemente um aumento da mão de obra disponível e uma maior produtividade agrícola. Praticamente desapareceram as grandes ondas epidêmicas, e o clima bélico vivido desde o séculoV diminuiu consideravelmente. Houve a melhoria de equipamentos técnicos e a ampliação dos espaços explorados, e, com isso, a natureza começou a ser estudada com a finalidade de poder extrair dela melhores rendimentos (Cortázar, 1990, p.133-5). Mereceu destaque também o progresso das artes mecânicas, como o moinho, que se tornou um elemento presente na paisagem tecnológica do camponês.

Essas melhorias levaram o camponês a ultrapassar os limites impostos por seu mundo e a lançar-se à aventura de explorar novas terras, um fenômeno denominado arroteamento, ou seja, colocar em cultivo uma terra até então inexplorada (Duby, 1980, p.215-6). Isso demonstra uma mudança de mentalidade em que esse camponês como pioneiro ou colonizador buscou novas terras porque não temia mais regiões desérticas. 
Durante esse período de expansão econômica, surgiram novos marcos de relações sociais. Em primeiro lugar, houve uma mudança no tipo de unidade familiar, pois a antiga família extensa de origem germânica foi substituída pela nuclear ou conjugal. A busca por novas terras levou ao fim das grandes famílias, passando a haver um incentivo à exogamia, sendo também importante o papel da Igreja nesse processo, já que ela passa a outorgar ao matrimônio a categoria de sacramento. As comunidades camponesas que antes se baseavam na mobilidade e dispersão se transformaram nas primeiras aldeias configuradas como um conjunto de famílias nucleares que se autogovernaram por meio de reuniões de todos os membros. Entre suas responsabilidades, estariam a ordenação do território e a regulação dos problemas comuns, o que criava fortes laços entre os componentes da aldeia.

Muitos desses agrupamentos de camponeses estavam ligados a fenômenos religiosos, pois paróquias e cofradias serviram para unir os membros dessas comunidades. O templo era o lugar das reuniões, e o sino servia para convocar os camponeses não apenas para a missa, mas também para resolver as questões relativas à comunidade (Le Goff, 1984, v.2, p.73). As cofradias, compostas por indivíduos que tinham por objetivo fazer obras de caridade, também se converteram em uma nova forma de coesão para o grupo de camponeses. Porém, essa forma idílica de igualitarismo social terminou rápido, pois os senhores feudais perceberam que incentivar a formação de aldeias era uma nova forma de controlar os camponeses. Sendo assim, a sociedade da época prosseguiu feudal, com uma parte da população subjugada por uma elite senhorial.

Nesse período, o camponês já não estava isolado, pois encontrou na aldeia e no que esta tinha de organismo de representação da comunidade uma célula, um marco jurídico de relação entre iguais. Nesses novos marcos de relação, foi possível conseguir o poder que o indivíduo não possuía e só o grupo podia conseguir.

A expansão monetária durante a Idade Média também acarretou mudanças sociais no campo, que deram origem a novos tipos de camponeses. A moeda circulava em abundância, principalmente nas 
cidades, mas logo chegou ao campo, pois havia grande investimento em melhorias tecnológicas e renovação de equipamentos agrícolas. Apareceu um novo conceito de riqueza não mais entendida como posse de terras, mas como capacidade econômica para comprar, vender ou investir, que logo se transformou num novo fator de distinção social.

As mudanças ocorridas nesse período começaram a afetar os camponeses não livres, que passaram a poder economizar dinheiro e mais tarde comprar sua própria liberdade. Os camponeses que tinham pequenas parcelas de terra passaram a produzir excedentes para levar ao mercado local e com esse dinheiro puderam substituir a prestação de serviços pessoais ao seu senhor, o que permitiu que eles dedicassem mais ao seu pedaço de terra ou a outros trabalhos paralelos. Dessa forma, percebemos que ocorreram mudanças no sistema clássico de exploração da grande propriedade, pois começam a desaparecer os antigos mansos, que foram substituídos paulatinamente por outros modos de possessão de terras, mais ajustados às necessidades do momento. Houve, por exemplo, a concessão de terras por um proprietário para usufruto de um camponês, mediante um contrato em que se fixavam as obrigações que o usufruidor deveria ter.

No topo do grupo de camponeses proprietários, encontravam-se os lavradores que investiam na melhoria de equipamentos técnicos, podendo ampliar suas antigas parcelas em um mercado imobiliário em expansão. Isso permitiu que eles alcançassem importante posição dentro das comunidades aldeãs, transformando-se na oligarquia que representou os interesses perante o poderoso.

Um resultado da corrente monetária no mundo rural foi o aparecimento do endividamento, tanto por parte daqueles que possuíam apenas uma parcela de terra como entre os pequenos proprietários. Os primeiros não conseguiam dinheiro para pagar o montante que substituía a corveia, e os segundos não conseguiam investir o mínimo em melhorias agrícolas. Em razão disso, os dois grupos se viram obrigados a vender sua força de trabalho para conseguir alimento. Indivíduos sem terras ou com minifúndios eram convertidos em proletários rurais. 
Os senhores, por sua vez, viviam das rendas geradas pelo domínio da terra e das que derivavam do exercício de poder mandar e castigar. Essas rendas eram obtidas por meio do poder jurisdicional e da aplicação das banalidades, ou seja, o pagamento pelo uso dos monopólios senhoriais, como o moinho e o forno.

Esse desnível entre senhores e camponeses vai levar ao início da crise do feudalismo, que se fez notar com mais intensidade a partir do século XIV.

No século XII, começaram a aparecer os primeiros sintomas do mau funcionamento do sistema econômico e social que, por vezes, estavam relacionados à dificuldade de manter uma economia rural de tipo extensivo, que só poderia existir mediante a ampliação do espaço. Isso era difícil, pois havia poucas terras propícias ao cultivo, levando à dificuldade de alimentar a população. Houve também mudanças climáticas que geraram más colheitas e desajustes dos preços. Como havia uma superpopulação, surgiram os problemas de abastecimento e o fantasma da fome voltou a assolar.

A partir do século XIV, surgiram as grandes epidemias de peste, e a Catalunha foi a zona espanhola mais afetada por essas infecções, o que gerou uma série de movimentos migratórios de camponeses em fuga de forma incontrolada dos locais afetados, provocando uma grave distorção dos esquemas demográficos do mundo rural. A guerra, também muito generalizada nesse século, produziu não só a morte em combate, mas também destruição de plantações, queima de aldeias etc., provocando uma diminuição da população camponesa e a desarticulação da estrutura econômica e do hábitat que a suportava. A fome, a peste e a guerra foram responsáveis pela destruição dos núcleos de povoamento.

Essas alterações proporcionaram o aparecimento de novas formas de exploração da terra e de trabalhos não agrícolas. Passaram a existir os arrendamentos de terras por períodos entre cinco e doze anos, o que propiciava a adequação da renda às oscilações do mercado. A renda era proporcional à colheita, e tanto o proprietário como o camponês ganhavam, pois o primeiro ganhou certa autonomia e o segundo pôde modificar o valor da renda a ser recebida de tempos 
em tempos. O novo mercado de trabalho para o camponês estava ligado às atividades artesanais, em que este recebia por peça terminada, e, geralmente, esse artesanato estava ligado aos setores têxtil, metalúrgico, da construção, do couro, do vidro etc. Essas tarefas acabaram se convertendo em um complemento à economia camponesa, baseada na exploração da terra.

Esse período foi extremamente conturbado, tendo ocorrido diversas revoltas camponesas contra a opressão em que estes viviam, pois muitos deles possuíam pouca liberdade. No caso espanhol, em 1480 , os reis católicos precisaram recordar que os solariegos tinham a mesma liberdade de domicílio e deslocamento que os demais naturais de Castela e também tiveram que reafirmar a condição de plena liberdade jurídica que correspondia aos homens de behetría e declarar a condição realenga de muitos dos lugares habitados por eles (Quesada, 1999, p.78).

Durante o auge do feudalismo, houve grande expansão agrária, aumento de produção e também de população, mas logo seguiram-se anos de crise quando grandes epidemias assolaram a Europa e os pequenos camponeses mais uma vez foram forçados a buscar o apoio de grandes senhores. Surgiram nesse período, como já vimos, várias instituições propiciadoras de dependência pessoal, bem como da perda de posse territorial.

Sabemos que, na história medieval espanhola, o marco de relação social fundamental, junto à família, foi a comunidade de aldeia e que teve na behetría sua mais importante expressão. Sua origem estava ligada aos modelos de aldeia romanos e germânicos, que tinham por características possuir uma agrupação camponesa com organização interna e posse territorial, uma personalidade jurídica e a consciência de fazer parte de uma comunidade capaz de organizar seu território. Mas, por causa das vicissitudes medievais, a comunidade perdeu o direito de se autogerir.

Os homens de behetría, embora tivessem liberdade jurídica, o que lhes permitia se deslocar e trocar de senhor quando assim considerassem necessário, ao se defrontarem com a nova realidade feudal, passaram a compor um novo tipo de quadro social de semisser- 
vidão. Tinham de trabalhar para o seu protetor, e a terra que antes era sua propriedade passa também ao controle de seu senhor. A comunidade aldeã é convertida em um local de armazenamento de mão de obra a serviço de um grande proprietário de terras, e esse grupo que antes tinha como principal vínculo a posse da terra perde-o em troca de proteção.

Com base nessas concepções de comunidade, poderemos tentar entender por que os cronistas do século XVI, ao tratarem das características familiares incas, as relacionaram constantemente com exemplos de organizações rurais próprias do medievo europeu em que o vínculo territorial era mais importante do que o consanguíneo.

\section{Os reis católicos (1469-1516) e a América imaginária}

Durante o reinado de Fernando e Isabel, os reis católicos, que uniram as coroas de Aragão e Castela por meio do casamento, a Espanha era um conjunto de territórios diversificados e não um único Estado.

Fernando e Isabel conseguiram pacificar os Estados espanhóis, pois estavam presentes em todas as localidades às quais fossem chamados, tendo viajado muito por todo o reino. Tinham consciência de que a paz nas cidades era indispensável para manter o território articulado, por isso fizeram alianças com as elites urbanas em cada reino (Kamen, 1984, p.40, 54).

No final do século XV, os Estados espanhóis eram pobres, e, enquanto em algumas regiões havia abundância de alimentos, em outras as pessoas morriam de fome. A falta de unidade política era seguida da desunião econômica. Os reis católicos precisavam solucionar esses problemas. Primeiro, expulsaram os árabes de seu último reduto, Granada, em 1492 e, no mesmo ano, foram procurados por Cristóvão Colombo, que, antes repudiado, recebeu a proteção de Fernando e Isabel, partindo para a sua primeira viagem, que culminou com a descoberta da América (ibidem, p.89-99). Com esse acon- 
tecimento, começaram as modificações econômicas, políticas e sociais nos Estados espanhóis, por causa dos metais preciosos que passaram a circular em Castela.

Castela foi o reino mais importante entre os Estados espanhóis desse período, pois tinha vários fatores a seu favor. A rainha Isabel formou um exército, desenvolveu a agricultura e o comércio, mandou codificar as leis de Castela ("Ordenanzas reais") e, por meio da centralização do poder, tentou implantar o Estado moderno, o que beneficiou o crescimento de Castela (Sanchez, 1945, p.273-80). Desse modo, Castela destacou-se e foi a responsável pela descoberta da América, pois daí partiram os anseios metalistas capazes de atender a uma sociedade em expansão.

Mesmo sendo um grande acontecimento, a descoberta da América não suscitou grande interesse por parte dos europeus, a não ser entre alguns humanistas e religiosos ou entre aqueles que tinham interesses profissionais, como é o caso dos mercadores. Isso se deve ao fato de que a Europa estava em pleno Renascimento, período em que as ideias humanistas imperavam e as antiguidades clássicas eram cultuadas (Elliot, 1984, p.22-7). Os cronistas da época sentiram uma grande dificuldade em descrever a singularidade da América, mas, diante da autoinsatisfação da cristandade do século XV, esta passou a ser descrita como o paraíso perdido em que os humanistas projetaram seus sonhos desencantados. Assim, a Europa, símbolo de corrupção, foi posta em oposição a essa América imaginária que representava a inocência (ibidem, p.34-9) e o local das utopias.

Para alguns cronistas, como Fernández de Oviedo (1959), a América simbolizava a possibilidade real de enriquecer, dependendo apenas da destreza de cada um. Não existe em Fernández de Oviedo (1959, p.361) um projeto de transformação coletiva de um território ou sociedade com a finalidade de alcançar uma organização social perfeita, o que existe é uma monarquia católica espanhola em processo natural de expansão em que os indivíduos que dele participam ganham a vida com seus trabalhos, o que para ele é legítimo. Cieza de León (1991) também segue a ideia típica dos conquistadores, de que o importante são os ganhos a alcançar nessas 
novas paragens. Preocupa-se com o resultado da conquista e colonização, mas, ao contrário de Fernández de Oviedo (1959), é extremamente otimista em relação ao assunto. León (1991) projeta no Novo Mundo seus planos de vida melhor, o que o leva a aproximar-se do discurso utópico em que a América se transforma no local propício a suas realizações pessoais. Ele não era possuidor de grandes conhecimentos, o que o afasta de um discurso utópico humanista, mas é interessante perceber essa versão simplificada da utopia renascentista.

Para López de Gómara (1946, p.156, 166), grande humanista, também era lícito pretender enriquecer-se na América, mas o mais importante era perceber que a conquista espanhola foi um ato providencialista de Deus para que a Espanha fosse a responsável pela conversão indígena e como prêmio deveria ser recompensada com as riquezas encontradas no Novo Mundo. A colonização da América não deixou de ser uma continuidade da Reconquista contra os mouros e da conversão dos hereges; sendo assim, os espanhóis estavam sempre a serviço de Deus.

Vários cronistas compartilharam da ideia de que a América era o lugar da utopia, da projeção de ideias e ideais que poderiam dar origem a uma nova sociedade, um novo homem, imaginado por cada um deles de acordo com seus interesses e desejos (Valcárcel Martínez, 1997, p.74). Por isso, para a América foram vários aventureiros, e, segundo Henry Kamen (1984, p.155), os pioneiros não eram nobres e sim espanhóis pobres, muitos soldados, marinheiros sem emprego e alguns jovens de poucos recursos, todos em busca da realização de seus sonhos.

Francisco Solano (1988, p.24-31) acrescenta que esses colonos-soldados, em sua maioria, tinham já idade madura, eram voluntários e desenvolveram nas Índias o mesmo ideário religioso da luta medieval. Assim, a conquista é uma cruzada e o conquistador um cruzado, porque a cruz é o símbolo que acompanha sua ação.

Desse modo, Castela transformou-se na potência dominante do mundo, graças à América. Os reis católicos conseguiram manter os Estados espanhóis articulados nesse período, mas começaram a so- 
frer com as graves tensões geradas pelas ideias de Reforma e Contrarreforma. Mesmo assim, trata-se de

[...] un período extraordinariamente rico y variado de la historia de España, en el cual una sociedad medieval reorganizada y rearticulada, cada vez más expuesta a las influencias intelectuales exteriores, se vuelca hacia el exterior en busca de un imperio de ultramar y se encuentra a sí misma inserta en una misión imperial y religiosa única. (Elliot, 1990, p.52)

Os espanhóis conquistaram a América e não necessitaram empregar grande esforço para isso, pois havia vários fatores a seu favor. Francisco Solano (1988) defende a ideia de que foi a falta de armamento adequado por parte dos indígenas e a divisão tribal em etnias que facilitaram a conquista. Guillermo Castillo (1988) remete à ação microbiana a culpa da derrota dos povos indígenas perante os espanhóis. Numa teoria que abarca mais fatores, Pedro Azancot (1988) enumera as diferentes enfermidades, a presença do cavalo e das armas e a introdução do gado europeu como elementos de destruição. A conquista da América é um episódio que merece um estudo mais aprofundado, não sendo, entretanto, esse o nosso objetivo.

Expusemos alguns dados sobre o contexto histórico da Espanha no período pré-conquista e no início do período colonial. Os conquistadores espanhóis, apesar de pertencerem à Idade Moderna, estavam imbuídos das categorias medievais, como a preocupação com a alma e o fanatismo religioso, o espírito de aventura e sua tendência a realizar-se em horizontes estranhos, e, embora tenham vindo em busca de ouro, ambição do homem moderno, não deixaram de lado a ortodoxia escolástica.

Esses homens que cruzaram o oceano em busca de sonhos, riquezas e movidos pela fé encontraram um mundo novo, exuberante, em que puderam realizar seus planos de expansão. De uma Espanha conflituosa, saíram tais homens comuns, desprovidos de grandes ensinamentos, que, no jogo da alteridade, aprenderam a desvendar-se e a olhar o autóctone americano com admiração, re- 
púdio, desconfiança ou, até mesmo, com benevolência, sentimentos antagônicos próprios de um encontro cultural.

Foi graças a esse processo que chegaram até nós as crônicas que representaram o mundo indígena de acordo com o que os cronistas conheciam. Muito embora, na história da Península Ibérica desde o final da Idade Antiga, tenha havido a presença de grupos de famílias extensas, na Idade Média o vínculo de parentesco perde a importância quando comparado ao territorial, e é essa a imagem que os espanhóis vão descrever em suas obras. Pelo fato de a documentação produzida por cronistas espanhóis e indígenas estar impregnada de noções europeias, faz-se necessária uma interpretação cuidadosa dessas obras para conhecermos os diversos significados atribuídos ao ayllu e as transformações ocorridas com essa estrutura no período colonial.

Para o conquistador espanhol, era necessário reorganizar a mão de obra indígena a seu favor, e, para tal, fizeram primeiro o repartimiento de índios e terras, depois instalaram o sistema de encomienda e finalmente planificaram as reduções. Percebemos que a concepção de comunidade, como organização medieval, é reempregada nas reduções do vice-rei Toledo, e, desse modo, origina-se a ideia de ser o ayllu uma comunidade, o que antes das reduções não existe. O ayllu é um grupo ligado por sistema de parentesco que possui ou não um território e que mantém relações de reciprocidade produtiva, enquanto a comunidade é uma organização colonial eminentemente territorial que tem por objetivo o armazenamento de mão de obra. Os cronistas não tinham como não recorrer às suas próprias tradições para descrever o mundo indígena, e, por isso, vemos, nas fronteiras discursivas encontradas em suas obras em conjunto com as práticas culturais vividas por espanhóis e índios, surgir a representação do ayllu pré-hispânico e colonial. 


\section{3 \\ REVIVENDO TEMPOS INCAICOS}

\section{As crônicas das Índias}

Os diversos documentos que tratam do processo de descobrimento, exploração, conquista e colonização do Novo Mundo são conhecidos pela denominação crônicas das Índias, e existem três tipos de texto: cartas-relatórios, relações geográficas e crônicas (Mignolo, 1982, p.57-116).

As crônicas possuem uma dimensão literária e também ideológica, e são reflexo do pensamento renascentista, mesclado a traços medievais em que os cronistas tentam assimilar mentalmente a realidade do Novo Mundo (Elliot, 1984). As expedições marítimas, financiadas, em sua grande maioria, pelo setor privado, foram responsáveis também pela produção de milhares de documentos. Grande parte das crônicas foi gerada como uma obrigação, já que o capitão da expedição tinha que descrever para o rei suas atividades e como eram as novas terras descobertas.

Havia outros motivos para a preparação desse tipo de documentação. Poderiam ser gerados documentos pela vontade própria de entender e dar a conhecer esse Novo Mundo, bem como com o intuito de mudar a situação pessoal, defendendo-se de algum 
processo judicial ou mostrando seus feitos na esperança de conseguir méritos da coroa. ${ }^{1}$

Dentre esses documentos, havia aqueles de ordem etnográfica que foram produzidos por cronistas que dominavam uma ou várias línguas indígenas, como Toríbio Motolinia (1914), Bernardino de Sahagún (1985), Diego de Landa (1966), Cristóbal de Molina, el cuzqueño (1959), Juan de Betanzos (1968) e outros, que foram os fundadores da etnografia e entenderam a dupla tragédia, militar e cultural, vivida pelos indígenas e os ajudaram com seus escritos a preservar a memória autóctone.

Quando se fala em invenção da América, esta representou a necessidade de forjar uma nova realidade social e cultural nesse Novo Mundo, mundo, não continente nem terra. A América aparecia como o lugar onde tudo podia ser modificado em oposição ao velho mundo. Isso originou ideias como as propagadas na obra Utopia, de Thomas More (s. d.), que é um exemplo do pensamento humanista. Utopia era o local onde imperavam o espírito de justiça social, a tolerância religiosa, a educação racional, a não violenta, o cultivo das virtudes cidadãs e instituições democráticas e o repúdio à violência e às guerras.

Apesar da influência do humanismo nessa época, poucos eram os cronistas das Índias que sabiam latim, algo essencial a um verdadeiro humanista. Suas preocupações eram de ordem material e de sobrevivência, e raros foram os que mostraram em seus escritos ecos utópicos.

Algo sempre presente nas crônicas e que reflete a tentativa de compreensão do outro é o processo de alteridade. Todorov (1983), pesquisador búlgaro, procura mostrar em sua obra que os espanhóis descobriram, conquistaram e depois procuraram conhecer para poder dominar. Cortez foi um dos que mais buscaram informações sobre o povo que ele almejava subjugar política e economicamente.

1 Como exemplo, podemos citar Diego de Landa (1966), que sofreu um processo judicial na Espanha, em virtude das arbitrariedades praticadas contra os índios e espanhóis em Yucatán. 
Já Las Casas (1958) tratou de compreender os povos indígenas para poder assimilá-los culturalmente.

Os cronistas possuíam diversos fins, mas todos descreveram e propagaram dados sobre o Novo Mundo, numa tentativa de integração intelectual desse mundo à mentalidade ocidental. Poucos realmente são os que chegam a entender o mundo indígena, pois, para tal, era necessário conhecer a língua desses povos.

Em geral, os cronistas eram homens de poucas letras, havia, inclusive, grandes conquistadores analfabetos, como é o caso de Francisco Pizarro e Diego de Almagro. No entanto, os cronistas liam muito ou pelo menos aquilo a que tinham acesso na América e tentavam fazer o melhor que podiam em suas obras. Apesar de terem motivos variados para realizar suas obras, todos tinham consciência de que a historiografia requeria retórica (Valcárcel Martínez, 1997, p.429), ou seja, que os livros de história deveriam ser redigidos em linguagem culta, elegante e respeitar a verdade dos fatos.

As crônicas das Índias são um testemunho vivo do encontro/desencontro da cultura europeia, nesse caso, a espanhola, com as culturas indígenas que habitavam o Novo Mundo. Quando nos referimos ao encontro desses mundos diferentes que mudaram o curso de suas histórias por causa dessa aproximação cultural, não podemos deixar de mencionar as tendências que constituíram o processo de aculturação, bem como os resultados desse cruzamento cultural ocorrido no início do século XVI. Percebemos que, além da queda e desestruturação do império dos incas, a conquista espanhola significou o despojo de seus meios de produção e a impossibilidade de voltar a organizá-los ao seu modo. Significou também a desarticulação das estruturas, e houve a aculturação religiosa ou sincretismo, visto que esses povos eram muito religiosos e viam no aparato eclesiástico europeu grande similitude com o deles próprios. Houve a desarticulação da organização social andina, que podemos exemplificar com nosso objeto de estudo, o ayllu.

Os espanhóis, ao descreverem o mundo andino, tinham uma visão etnocêntrica, pois tinham valores e juízos preestabelecidos. Dessa forma, era difícil captar o caráter social das instituições andinas. Não 
surpreende o fato de eles, a princípio, não terem entendido o significado do ayllu como estrutura de parentesco. O povo andino, por sua vez, passa a integrar-se ao mecanismo da aculturação, entendido aqui como um processo de adaptações e resistência.

Segundo os historiadores Clarke Simon (1996, p.83) e Nicholas Cooper (1996, p.86), que estudaram áreas conquistadas pelos romanos, o processo vivido pelos grupos autóctones foi de continuidade do que havia sido desenvolvido no período pré-romano, e, quando da chegada dos romanos, houve a adoção e adaptação de seus traços culturais dentro da cultura nativa. $\mathrm{O}$ mesmo aconteceu em relação aos grupos étnicos andinos que viveram um processo de interação recíproca com os europeus.

Quando examinamos contatos entre culturas diferentes, percebemos que o mais usual é que ocorra uma fusão cultural em que é frequente o predomínio de uma cultura sobre a outra, depois de um processo sempre complicado em que a recepção de elementos culturais implica seleção de uns, o repúdio de outros e ainda a modificação dos demais. O resultado é uma mescla sempre complexa e às vezes difícil de interpretar. Ocorrem também fenômenos de resistência que podem ser de cunho seletivo em relação a determinados elementos culturais ou de resistência total (Castillo, 1999, p.10-1). $\mathrm{O}$ que podemos perceber é que se faz necessário entender de que modo os grupos étnicos andinos modificaram seus valores e suas tradições perante os ocidentais. Pela análise das crônicas, podemos interpretar as transformações ocorridas durante o período colonial desde a conquista do Tahuantinsuyu.

Esses textos são resultantes do processo de alteridade vivido entre culturas distintas e, por isso, representam as práticas culturais do século XVI em que os grupos étnicos andinos foram forçados a alterar seu modo de vida diante do novo, o que não significa que se subjugaram aos espanhóis. Quando mencionamos que os cronistas indígenas possuíam um discurso aculturado, temos em mente a representação discursiva de seu mundo de acordo com suas necessidades de sobrevivência (Stern, 1987). Prova disso são as crônicas de Titu Cusi, Guaman Poma de Ayala e Garcilaso de la Vega, 
que alertam para os danos causados pelos conquistadores espanhóis manipulando o discurso de modo a alcançar seus interesses, que podiam ser pessoais ou coletivos. A colaboração com os europeus, por vezes, significou uma forma de resistência sem o uso da violência.

Conforme Serge Gruzinski (1986, p.415) demonstrou, as mudanças culturais ocorridas nesse período propiciaram possibilidades de reorganização dos grupos indígenas diante do vazio provocado pelo sistema colonial.

Percebemos então que, no caso andino, não houve a passagem da cultura indígena para a cultura ocidental, mas, sim, o processo inverso, em que a cultura indígena integrou os elementos europeus. Como os incas estavam acostumados a produzir excedente econômico e a pagar tributo, os espanhóis aproveitaram o sistema preexistente para controlar a mão de obra. Para isso, contavam com a ajuda de chefes locais que mantinham, como antes, a ligação entre senhores e súditos. Essa administração indireta favoreceu a manutenção das tradições indígenas, apesar da ação espanhola em sentido contrário por meio da evangelização e das reduções (Wachtel, 1976b, p.114-5) que, desde o momento inicial da conquista, eram um instrumento para justificar suas pretensões políticas (Pietschmann, 1992, p.16). Os documentos indígenas são resultantes dessa mescla: por um lado, há a influência dessa "aculturação", pois os cronistas retratam sua cultura com visão ocidentalizada, e, por outro, faz-se uma apologia ao mundo andino (cf. Burke, 2000, p.255-67).

Tais relatos originam-se da confluência de discursos representativos de culturas distintas. A utensilagem mental (Febvre, 1988, p.328) do espanhol só lhe permitia reproduzir aquilo que via de acordo com seus próprios traços culturais. $\mathrm{O}$ indígena que passou pelo processo de aculturação não apagou de sua memória a própria cultura, apenas passou a filtrá-la sob influência dos modelos europeus. Ao analisarmos documentos dos séculos XVI e XVII, que abordam a história andina no período incaico e colonial até a época de Toledo, estamos lidando com um conjunto de informações que são a representação desse mundo indígena, aos olhos de europeus e de mesti- 
ços e autóctones influenciados por traços culturais espanhóis. Os textos resultantes dessa confluência cultural representam uma nova realidade, que acabará por ser assimilada e sociabilizada.

Podemos concluir que as crônicas espanholas e indígenas resultam dessas práticas culturais vividas no século XVI, que expressam distintos processos adaptativos e até de resistência. A tão aclamada vitória espanhola sobre os incas reflete a tragédia vivida por esse povo que teve seu mundo transformado. As crônicas fornecem-nos representações da história do descobrimento e conquista do Peru, bem como de todo o período de colonização. Como já abordamos na primeira parte deste livro, as crônicas refletem discursos distintos de grupos que se encontraram numa fronteira intercultural, ${ }^{2}$ que permite sua transposição, mas em que estes dificilmente perdem suas próprias características. O processo de alteridade e de aculturação e as representações do mundo indígena se originam nessas fronteiras discursivas, em que os discursos do espanhol e do autóctone se encontram ou divergem, mostrando as imagens desses dois mundos em contato.

\section{Mitos de origem}

Homens ávidos por riquezas chegaram às terras incaicas imbuídos de um espírito conquistador e não mediram esforços para submeter essa população. As crônicas surgidas ao longo desse período de conquista e colonização, principalmente durante o primeiro século, representam o processo de alteridade vivido por esses povos e

2 "La interculturalidad no apunta pues a la incorporación del otro en lo propio, sea ya en sentido religioso, moral o estético. Busca más bien la transfiguración de lo propio y de lo ajeno com base en la interacción y en vistas a la creación de un espacio común compartido determinado por la convivencia. La meta de la convivencia no debe confundirse en ningún caso com la 'pacificación' de las (conflictivas) controversias entre las diferencias, mediante la reunión de las mismas en una totalidad superior que se las apropria y armoniza" (Fornet-Betancourt, 2001, p.47). 
são um importante acervo etnográfico que nos permite conhecer melhor o mundo indígena dessa região da América. Antes de aprofundarmos nossas análises sobre a representação do ayllu durante o século XVI, conheceremos alguns traços culturais e a história do povo inca expressos em crônicas e documentos diversos.

Cieza de León e Francisco de Ávila relataram ter ouvido dos incas que, em tempos anteriores à sua presença nessa terra, houve um dilúvio que matou quase todos os seres humanos, e o mundo esteve em vias de desaparecer. Alguns homens e mulheres se salvaram porque se esconderam em cavernas em montanhas bem altas e, depois que a tormenta passou, daí saíram e começaram a multiplicar-se, repovoando a terra.

Depois disso, como esses homens viviam como feras, sem religião nem ordem, sem plantar as terras e andavam nus, o deus Sol se apiadou deles e mandou à terra seu filho e sua filha para que os doutrinassem e os ensinassem a cultivar a terra, criar animais, viver em casas e povoados e lhes predicassem leis para que soubessem viver como homens racionais e não como bestas. Assim, o deus Sol colocou seus filhos no Lago Titicaca e lhes disse para irem por onde quisessem e, onde parassem para comer ou dormir, sempre fincassem no chão a varinha de ouro que levavam com eles. Onde essa vara afundasse de um só golpe, deveriam fundar um novo povoado. Depois de reduzir o povo que vivia nas redondezas a serviço do deus Sol, deveriam mantê-los em ordem e justiça e tratá-los sempre com piedade. Os filhos do Sol assim fizeram e, no local onde a vara de ouro afundou, criaram Cuzco (La Vega, 1991, v.I, p.39-42), cidade que se tornaria a capital do Tahuantinsuyu.

Esse é um dos mitos da origem dos incas que nos conta La Vega (1991) com grandes pormenores, porém Cieza de León (1991, v.2, p.13-5) relata uma versão um pouco diferente. Segundo ele, os homens também viviam em grande desordem quando saíram de Pacarec Tampu, uma caverna que se localiza próximo a Cuzco, três homens e três mulheres. Os homens que daí saíram se chamavam Ayar Uchu, Ayar Hache Arauca (Ayar Cachi) e Ayar Manco. As mulheres eram Mama Huaco, Mama Cora e Mama Rahua. Saíram 
vestidos de reis, e um deles tinha uma atiradeira de ouro e nela posta uma pedra. Como era muito forte e com suas pedras derrubava até montanhas, provocou a inveja de seus irmãos, e assim estes convenceram Ayar Cachi a voltar à caverna, onde o encarceraram. Prosseguiram suas andanças sem Ayar Cachi e onde chegavam fundavam novos povoados.

Semelhante a essa história é a outra versão exposta por La Vega (1991, v.I, p.46-8) que também descreve os irmãos Ayar como fundadores do Tahuantinsuyu. Esse cronista diz que eram quatro homens e quatro mulheres, todos irmãos. Saíram de Paucartampu e os primeiros irmãos, Manco Capac e Mama Ocllo, fundaram Cuzco, que na língua dos incas significa umbigo. Os incas descenderam desse casal, pois foram eles que subjugaram as nações vizinhas a Cuzco e os ensinaram a ser homens. La Vega questionou a importância dos outros irmãos Ayar, mas não obteve resposta contundente, aludindo tal resultado ao mundo de fábulas inventadas por esses povos.

O vocabulário cristão encontrado em todos os discursos dos cronistas, espanhóis ou não, por vezes, tendeu a transformar a história oral incaica numa espécie de catecismo, que, mesclado às noções administrativas espanholas, criou uma nova representação da sociedade indígena.

Esses discursos espelham a luta de alteridade (Todorov, 1983) vivida nos primeiros tempos de conquista, bem como a incompreensão da sociedade andina por parte dos espanhóis. Um exemplo disso é a dualidade de governo incaico, a qual os cronistas tiveram dificuldade de expressar. As únicas alusões ao poder dual são as que aparecem nos mitos dos irmãos Ayar, sucintamente abordados anteriormente e que, conforme os estudos de Canseco (1988a), Duviols (1980) e Zuidema (1964), comprovam a dualidade do poder incaico.

Ao tratar dos grandes chefes incas, os cronistas não se eximem de comentários preconceituosos, visto que rebaixar a autoridade destes era uma forma de legitimar o poder espanhol sobre eles. Para Sarmiento de Gamboa (1988), os incas foram tiranos que governaram o Peru desde 565 da era cristã até 1533, quando chegaram os espanhóis e implantaram o poder real em nome de Carlos V. 
Manco Capac foi o primeiro chefe do Tahuantinsuyu, e Mama Ocllo, sua esposa. La Vega (1991, v.I, p.44-6) nos conta que Manco Capac mandou fundar mais de cem povoados na região do Paucartampu, próxima a Cuzco, e esse foi o início de toda a conquista. Ele não relata a cronologia incaica, pois, ao que parece, nem eles sabiam ao certo, visto ser uma história antiga demais para ser guardada de memória.

É possível supor que, no início da conquista incaica, ainda imperasse o sistema matriarcal, conforme os relatos de Guaman Poma de Ayala (1993, v.I, p.64). Ele se refere a Mama Huaco como uma mulher muito bonita e feiticeira que, no começo dos tempos, se casou com seu próprio filho, Manco Capac Inga. Ela falava com as huacas e com os demônios, e dela saíram todos os futuros chefes incas. Foi muito amiga do povo e governava mais que o seu marido Manco Capac Inga sobre toda a cidade de Cuzco e jurisdição. Todos lhe obedeciam e respeitavam-na, pois fazia milagres com a ajuda de demônios.

Esse relato nos remete a finais do século XVI, período em que se instalou a Inquisição em Lima. Mulheres ditas bruxas começaram a ser perseguidas. $\mathrm{Na}$ verdade, estas não passavam de simples curandeiras que conheciam plantas medicinais e que, por isso, eram muito respeitadas em suas comunidades. Temendo o poder que essas mulheres tinham junto aos curacas (chefes locais), os quais sempre recorriam a elas em busca de conselhos, a máquina administrativa da coroa espanhola facultou a perseguição delas, utilizando, para tal, a Igreja. Começaram a aparecer então as histórias normais de um discurso inquisitorial, ou seja, bruxas são as maiores aliadas do diabo e conhecem o poder das plantas para produzir malefícios a outrem (Silverblatt, 1990). A perseguição não se restringiu às mulheres, pois homens também foram acusados de ser dogmatizadores e feiticeiros, pelo mesmo motivo já apresentado (Portugal, 1998). Guaman Poma de Ayala (1993), como indígena cristianizado, escreveu sua crônica dentro dos modelos religiosos assimilados e de acordo com a realidade que estava vivendo, não podendo deixar de mencionar o poder do demônio nas mais variadas circunstâncias da história incaica. 
O discurso aculturado do mestiço La Vega (1991) traz à tona uma série de conceitos alheios ao mundo andino, quando este, ao descrever o mandato de Manco Capac, aborda em minúcia o momento em que este resolve apresentar o seu testamento.

Manco Capac reinou cerca de trinta anos, não se sabe ao certo. Perto de sua morte, chamou os filhos, a esposa Mama Ocllo Huaco e as esposas secundárias.

Llamó asimismo a los más principales de sus vasallos y por vía de testamento les hizo una larga plática, encomendando al príncipe heredero y a sus demás hijos el amor y beneficio de los vasallos, y a los vasallos la fedelidad y servicio de su Rey y la guarda de las leyes que les dejaba, afirmando que todas las había ordenado su padre el Sol. Con esto despidió a los vasallos, y a los hijos hizo en secreto otra plática, que fue la última, en que les mandó siempre tuviesen en la memoria que eran hijos del Sol, para respetar y adorar como a Dios y como padre. (La Vega, 1991, v.I, p.60)

Para La Vega, o natural era utilizar vocábulos próprios da cultura espanhola, que tinha por característica a vassalagem devida a príncipes e reis, coisa que era distinta entre os incas. Os povos submetidos pelo povo inca não lhes deviam vassalagem, conforme o antigo modelo feudal europeu, eram, sim, inseridos em um processo de reciprocidade e redistribuição controlado pelos chefes do Tahuantinsuyu. Porém, ele escreveu para espanhóis.

A genealogia incaica traçada por alguns cronistas não demonstra a dualidade de poder existente, visto que só conheciam o poder monárquico. Por isso, enumeram os incas dinasticamente, começando por Manco Capac, que foi sucedido por seu filho Sinchi Roca e sucessivamente até Atahualpa. Betanzos (1968), que foi um dos cronistas a esboçar uma lista dos incas, nem sequer menciona Huascar, que, no momento da conquista, compartilhava o poder com seu irmão Atahualpa. As lutas entre os dois irmãos ficaram amplamente conhecidas (Cieza de León, 1991, p.202-8), sendo um dos argumentos explicativos da derrota incaica diante da pequena quantidade de espanhóis que submeteram Atahualpa e o seu povo em Cajamarca. 
Os cronistas dão por encerrada a história da "dinastia incaica", que governou e doutrinou os povos andinos, a partir do momento em que chegaram os espanhóis. Não compreenderam o sistema político andino, pois era demasiadamente difícil para homens com mentalidade de fins do medievo assimilarem o novo, o diverso, sem realizar comparações com seus próprios modelos, o que os privou de uma factível interpretação do outro.

\section{Um império construído pela reciprocidade e redistribuição}

No período inicial de expansão, a reciprocidade foi responsável pelo rápido crescimento do Tahuantinsuyu, pois o soberano inca presenteava seus vizinhos que viviam organizados em ayllus e, em troca, recebia força de trabalho. Isso significa que "la autoridad no se ejercía directamente, sino a través de la reciprocidad y de la minka" (Canseco, 1988a, p.62; Holguin, 1989, p.240).

O Inca tinha que "rogar" ajuda aos curacas de outras etnias e dar-lhes mulheres, objetos sagrados, coca etc. Para isso, precisava ter uma grande quantidade de bens para oferecer. ${ }^{3}$

Isso aumentou a produção agrícola e de gado, proporcionando o excedente tão necessário para a manutenção das ligações recíprocas com outras etnias. No artigo "La guerre et les rebéllions dans l'expansion de l'État inka”, John Murra (1978) mencionou a importância, para a expansão inca, dos casamentos entre o Inca e as filhas de chefes locais.

O Tahuantinsuyu expandiu-se rapidamente através do sistema de reciprocidade inicial, que tinha por objetivo adquirir força de trabalho. Segundo Craig Morris (1978, p.945), uma das razões que

3 "Es de suponer que a medida que se ampliaban las conquistas, el número de curacas unidos al Inca por reciprocidad y por lazos de parentesco fue aumentando, lo que dio como resultado una afluencia cada vez mayor de fuerza de trabajo al Cuzco" (Canseco, 1988a, p.65). Ver Betanzos (1968, p.65). 
permitiram o incrível crescimento do Tahuantinsuyu repousa justamente sobre o feito de que numerosos aspectos de sua economia ficavam inseridos na estrutura sociopolítica primitiva, mesmo enquanto a autoridade central se fazia cada vez mais secularizada, militarizada e centralizada. Os incas conseguiram manter - pelo menos de uma maneira fictícia - os laços pessoais e rituais que estão na base de todo o sistema de relações recíprocas.

No começo do desenvolvimento incaico, a reciprocidade regulava as relações entre os senhores da área cuzquenha. O poder do Inca era limitado, não podia simplesmente mandar, necessitava pedir aos outros chefes étnicos que o ajudassem a realizar as tarefas importantes para o crescimento do domínio inca.

O estudo da reciprocidade aplicada ao incário pode ser dividido em duas etapas: a reciprocidade durante o período de expansão inca e, depois, quando o Tahuantinsuyu está consolidado. Na última etapa, a reciprocidade aparece ligada à redistribuição.

Segundo Marcel Mauss (1974, v.II, p.45), na reciprocidade as prestações e contraprestações são feitas de uma forma sobretudo voluntária, por presentes, embora sejam, no futuro, rigorosamente obrigatórias, sob pena de guerra privada ou pública.

No período inicial da expansão inca, ocorria essa troca de presentes por trabalho. Porém, quando o Tahuantinsuyu cresceu, esse tipo de reciprocidade tornou-se impraticável, pois o Inca não podia mais ir de aldeia em aldeia "rogar" ao chefe local que o apoiasse, oferecendo-lhe presentes e festas para tal.

Os soberanos incas, para libertarem-se do cumprimento das regras estabelecidas pelo sistema de reciprocidade inicial, pelo menos no que tange às etnias rebeldes, valeram-se dos yanas para solucionar seus problemas. Os yanas eram pessoas retiradas de seus ayllus de origem para cumprir tarefas e trabalhos e que não entravam nas tarefas comunais de suas parcialidades e povoados (Canseco, 1976, p.346).

Quando um grupo étnico não se submetia a Cuzco, então o soberano inca colocava no lugar do chefe local um yanacona de sua confiança. Desse modo, não necessitava manter a reciprocidade com essa etnia, já que os yanas estavam fora do sistema de "rogos". 
Apesar de ter representado uma situação incômoda para os soberanos incas, a reciprocidade foi fundamental para a manutenção de seu poder e para o crescimento do Tahuantinsuyu (ibidem, 1988a, p.70-1).

Quando o domínio incaico se estabeleceu por grandes extensões de terra, foi necessário fazer diversas obras como: centros administrativos, depósitos, estradas e outras construções para facilitar a reciprocidade e, também, a redistribuição de bens dentro do Tahuantinsuyu.

Karl Polanyi (cf. Polanyi et al., 1957) foi o primeiro pesquisador a trabalhar com a noção de economia redistributiva, ao analisar as economias antigas e a organização econômica de grupos étnicos não ocidentais.

John Murra (1983), em sua tese de doutorado La organización económica del Estado inca, defendida em 1955 e publicada em espanhol pela primeira vez em 1978, expõe suas ideias sobre a economia incaica, baseando-se na noção de redistribuição, conforme os dados de Polanyi et al. (1957), e de reciprocidade.

Al caracterizar el sistema económico inca como redistributivo, le atribuimos al estado el papel principal en el intercambio de bienes. El estado recibía la mayor parte del excedente de la producción campesina y de los artesanos a su servicio, y a su vez redistribuía la mayor parte de estos productos entre diversos segmentos de la población, de acuerdo con una lógica estatal. (Murra, 1983, p.198)

Os estudos de Murra $(1975,1983)$ permitiram perceber que o Tahuantinsuyu não se fundamentou em um poder totalitário, e, sim, numa organização baseada na reciprocidade e na redistribuição.

El Tawantinsuyu se fue convirtiendo de esta manera en un organismo capaz de organizar una redistribución de bienes y servicios a cambio de la entrega de la energía humana de la población, organizada de tal modo que dicha energía puede ser considerada como suplementaria, y no afectaba el acceso directo a los recursos por las unidades étnicas. (Pease, 1992b, p.19) 
Conforme a análise de Maurice Godelier (1977, p.336-7), antes do domínio inca, as relações de produção de uma etnia baseavam-se nos laços de parentesco. Quando o Tahuantinsuyu integrou todos os grupos étnicos ao seu sistema econômico recíproco e redistributivo, as relações de produção passaram a basear-se em relações político-religiosas, representadas pelo Inca, filho do deus Sol.

O Estado inca, para satisfazer as necessidades de sua produção, fez uso das tradicionais relações de reciprocidade dentro do ayllu, fornecendo, para tal, os utensílios e as sementes necessárias e fazendo que as pessoas trabalhassem em trajes de festa, com música e cantos, conforme seus rituais.

As antigas relações de parentesco e as antigas relações políticas aldeãs e tribais, sem mudarem de forma nem de estrutura, tinham a partir de então mudado de função, uma vez que estavam encarregadas de fazer funcionar um novo modo de produção. (Godelier, 1977, p.333)

Para que esse sistema funcionasse, era realmente necessário que o trabalho fosse ritualmente solicitado pela autoridade local, por isso, não é de estranhar que habitantes de Chucuito, ao serem interrogados pelo visitador Garci Diez de San Miguel (1964, p.111, 117) sobre o que davam a seus curacas, responderam que em um determinado período não plantaram suas terras, porque não lhes haviam pedido.

O território inca expandiu-se em tempos de Pachacutec, Tupac Yupanqui e Huayna Capac, por meio da reciprocidade ou das armas. De acordo com Canseco (1988a, p.116-22), nos locais mais afastados, onde não era conhecido o costume andino da reciprocidade, as etnias resistiram ao domínio incaico por meio de batalhas sangrentas. Os cronistas, ao tratarem desse assunto, basearam-se em sua própria experiência na conquista dos Andes, não retratando as noções que regiam as relações entre os homens andinos, diferentes das utilizadas pelos europeus no século XVI. Assim, as crônicas nos fornecem versões das conquistas incaicas que são discutíveis.

Na época do domínio de Huascar, não restava muito que conquistar, mas coube-lhe enfrentar seus opositores, ou seja, elementos da 
nobreza incaica que queriam seu irmão Atahualpa no poder. Houve diversos enfrentamentos entre os dois incas, mas Atahualpa acabou vencendo, como verificaremos mais detalhadamente a seguir.

Conforme a periodização de Waldemar Espinoza Soriano (1990, p.111), Pachacutec foi o soberano de 1438 a 1471, Tupac Yupanqui de 1471 a 1493, Huayna Capac de 1493 a 1527, Huascar de 1527 a 1532 e Atahualpa de 1532 a 1533. Esses incas foram responsáveis pela expansão e formação do Tahuantinsuyu.

\section{Sociedade inca}

A sociedade inca teve como uma das principais características a dualidade que se manifestou na divisão existente nos grupos étnicos e nas regiões do Tahuantinsuyu. Esse sistema dual originou-se nas relações de parentesco, e uma de suas funções era fazer funcionar a reciprocidade. ${ }^{4}$ Os cronistas estabeleceram as dinastias incaicas em sequência, porque concebiam o poder individual, favorecendo os incas de Hanan, visto que estes estavam no poder quando da invasão espanhola. Embora, nas crônicas, não apareça especificada a dualidade, sempre se mencionam pares de curacas das diversas regiões do Tahuantinsuyu. Eles representavam as metades de seu sistema organizativo, Hanan (de cima) e Hurin (de baixo). Em alguns documentos administrativos, por exemplo, nas visitas coloniais, a dualidade dos curacas aparece demonstrada, como no caso dos lupacas (San Miguel, 1964) e na Visita de Acari (1973).

A dualidade entre os soberanos cuzquenhos fazia parte do processo de seleção para ascender ao poder. ${ }^{5}$ Porém, os cronistas apre-

4 "El dualismo se manifestaba en la organización de los ayllus o grupos de parentesco, que aparecen agrupados en 'parcialidades' hanan o urin, alaasa o masaa, uma o urco, allauca o ichoc, en distintos lugares de los Andes. Dichos términos pueden ser entendidos como alto-bajo, derecha-izquierda, masculino-femenino, dentrofuera e, incluso, cerca-lejos y delante-detrás" (Pease, 1992a, p.103).

5 "En los primeros tiempos del Incario, la herencia del poder recaía sobre um hijo del gobernante y en caso de alguna emergencia la decisión la tomaba un consejo de 
sentaram a transmissão do poder entre os incas segundo o modelo europeu. Dessa maneira, podemos entender por que os cronistas descreveram uma sucessão dinástica, na qual o filho mais velho recebia por herança o poder do pai falecido, de acordo com o modelo de monarquia hereditária. Incorporaram à história dos incas os conceitos de legitimidade e primogenitura, bases do sistema europeu de transmissão de propriedade e também de poder real ou senhorial, mas diferentes ou até inexistentes entre os incas. O sistema de herança do governo mediante primogenitura de tipo europeu não se encontra na região andina, conforme o resultado de pesquisas sobre o sistema de parentesco andino, baseado no regime de família extensa. John H. Rowe (1963, p.247) mostrou que as crônicas generalizavam quando afirmou a existência de um sistema de designação de sucessores entre os homens andinos, mesmo sem uma regra detalhada para tal.

A estrutura social no Tahuantinsuyu era composta pela elite governante e administrativa, por sacerdotes, mercadores, artesãos, pescadores, hatun runa, mitmaq, yanas, acllas e piñas.

O soberano do Tahuantinsuyu recebia a denominação de Sapa Inca ${ }^{6}$ e juntamente com as panacas ou ayllus reais formava a aristocracia incaica.

dignatarios. Los varios candidatos trataban de atraer hacia sí la ayuda de sus parientes. No existió la primogenitura ni la bastardía como sustento de la legitimidad. En teoría todos los hijos de un soberano tenían iguales derechos a la mascapaicha. Una consecuencia de este sistema hereditario fueron las intrigas, rebeliones y violentas eliminaciones de los candidatos. En un esfuerzo por suprimir las luchas, se dio inicio durante el gobierno de Inca Roca al correinado, es decir a la asociación del hijo elegido al gobierno del padre. El corregente compartía las tareas administrativas y militares, pero su nombramiento podía ser revocado por el inca. En los últimos gobiernos el sistema se fortaleció con la sucesión del 'más capaz' de los hijos de la coya, la única reina de entre las muchas mujeres del inca. Por último, en un mayor esfuerzo por eliminar a los candidatos se estableció durante el cogobierno de Tupac Yupanqui, el matrimonio incestuoso con una hermana, hecho que reforzaba el derecho del heredero por ser el hijo de la hermana del inca" (Canseco, 1993, p.38-9).

6 Sapa Inca: “de sapa: grande. Inca principal sobre los demás” (Canseco, 1988a, p.299). 
O Inca era considerado sagrado, visto ser descendente do deus Sol. Desse modo, seu poder não era apenas político, mas também religioso. Ele era responsável pela manutenção das relações de reciprocidade e redistribuição com os grupos étnicos anexados ao Tahuantinsuyu. Além disso, intervinha nos conflitos de tais grupos, comportando-se como se fosse o senhor local, mas de nível superior.

No início da expansão, o Inca contraía casamento com mulheres de outras etnias, visando à reciprocidade baseada em laços de parentesco. Depois, passou a ter como esposa principal a Coya, que pertencia à sua própria panaca. As esposas secundárias pertenciam a diversos grupos étnicos incorporados ao Tahuantinsuyu. A poligamia era admitida entre a elite. ${ }^{7}$

O Inca contava com a ajuda de um corpo administrativo para organizar as tarefas estatais regionais. O Tocricuc era o governador incaico em uma determinada região; o Michiq foi identificado pelos cronistas como tenente de governador; o Tucuyricuc era um funcionário que atuava como um inspetor do Inca e que viajava pelas diferentes regiões do Tahuantinsuyu, recolhendo informações e resolvendo conflitos locais; finalmente, o Quipucamayoq foi identificado como o especialista no manejo dos quipus ou instrumento com fins contáveis (Pease, 1992a, p.115).

Os senhores dos grupos étnicos, os curacas, foram de grande importância para a organização do Tahuantinsuyu, pois assumiam dupla função ao atuarem como administradores do sistema local no nível do ayllu e ao representarem o poder intermediário entre o Estado inca e seu ayllu, com a finalidade de satisfazer a rede estatal de abastecimento. O curaca era o personagem encarregado do governo

7 "Un buen sapainca cumplía sus deberes religiosos para que los dioses nunca le negaran sus dones. De hecho era un sacerdote, aunque él ya no ejercía ese cargo oficialmente, bien que intervenía en la designación de los sumos sacerdotes. Cabalmente por eso se le creía que hablaba con las divinidades y consultaba a otros oráculos para dictar sus decisiones" (Solano, 1988, p.314). 
local, tendo como uma de suas funções canalizar parte do excedente da produção do ayllu para fins de provisão social. Ao incorporar distintos senhorios, etnias e outros ao Estado inca, o curaca local mantinha suas faculdades de centralizador dos recursos comunitários, mas convertendo-se em sujeito das disposições cuzquenhas (Gabai, 1980, p.10).

Conforme a análise de Canseco (1988a, p.199), os incas no início foram simples curacas e, ao formarem o Tahuantinsuyu, estabeleceram sua organização interna sobre a já existente, ou seja, sobre o modelo de curacazgos. As macroetnias funcionaram como núcleos redistributivos locais.

Segundo essa pesquisadora e conforme demonstramos anteriormente, houve um sistema dual nos curacazgos, pois cada grupo anexado ao Tahuantinsuyu enviava um senhor para Cuzco, assegurando a fidelidade de sua etnia ao poder incaico. No curacazgo, ficava outro curaca que orientava as tarefas do ayllu em relação ao Estado (ibidem, p.183). Os curacas desempenharam um papel primordial no funcionamento da organização do Tahuantinsuyu.

Os sacerdotes eram importantes na sociedade incaica, pois detinham o conhecimento mítico e faziam previsões do futuro falando com as huacas, ${ }^{8}$ com os mortos (Balboa, 1951, p.287-8) e sacrificando animais para obter respostas. Havia uma hierarquia religiosa, mas a autoridade máxima era o Villac Umu, que era responsável pelo templo do Sol em Cuzco, o Coricancha. ${ }^{9}$ Nenhum ato importante era realizado em Cuzco sem consultar a callpa, ${ }^{10}$ ou seja, retirava-se o coração ainda palpitante de um animal para nele ler os augúrios. Os ichuris, em Cuzco, cumpriam funções de confessores e os socyacs prediziam o futuro através de grãos de milho. Os ritos e cerimônias

8 Huaca: "o guaca, templo del ídolo o el mismo ídolo" (Canseco, 1988a, p.296).

9 “Este, llamado Coricancha ('recinto de oro') o Intihuasi ('casa del Sol'), era el más antiguo, el más sagrado y el más rico de todos los templos del Tahuantinsuyu [...]" (Curatola, 1994, p.255).

10 Callpa: "Las fuerças y el poder y las potencias del alma, o cuerpo" (Holguin, 1989, p.44). 
para a Lua e a terra estavam sob a responsabilidade da Coya ou rainha e das mulheres da elite cuzquenha (Canseco, 1988a, p.206-8).

Na costa peruana, havia um grupo especializado em praticar o intercâmbio e a troca. Esses "mercadores" 11 não utilizavam moeda, só troca de produtos, e os que mais desenvolveram essas funções foram os de Chincha e os da costa norte. Os "mercadores" de Chincha costa sul - navegavam até o norte (atual Equador), levando cobre para intercambiar por mullu, conchas vermelhas, que foram objeto especial de troca pelo seu caráter sagrado, sua grande demanda e por só se encontrar em águas tíbias e não no litoral peruano, banhado por uma corrente fria (ibidem, 1989, p.286).

Os "mercadores" da região costeira equatoriana chamavam-se "mindala" (Salomon, 1978, p.974) e trocavam diferentes produtos, e suas categorias sociais variavam, pois havia desde simples mercadores a senhores principais que trocavam roupa de lã. Havia também funcionários menores que só produziam e trocavam sal (Canseco, 1989, p.288-9).

$\mathrm{Na}$ costa, o ofício desempenhado tinha grande importância para o modelo organizativo da região. Cada indivíduo tinha sua especialização e dedicava-se a ela com exclusividade. Os "mercadores" eram responsáveis pelo intercâmbio de produtos e os artesãos tinham funções definidas: uns podiam ser ceramistas e outros, especialistas em arte têxtil. ${ }^{12}$

Os artesãos destacaram-se não só pelos seus produtos de alta qualidade, mas porque as suas tarefas eram fundamentais para o funcionamento da reciprocidade, pois o inca utilizava os tecidos, as cerâmicas e demais objetos artesanais para presentear quem necessitasse agraciar.

11 “[...] estos especialistas fueron llamados por los españoles como 'mercadores' [...]" (Canseco, 1988a, p.208).

12 "Los artífices gozaron en el incario de una situación particular, y si bien trabajaban para el Estado, sólo lo hacían en sus oficios, sin tomar parte en la mita guerrera o agraria" (Canseco, 1988a, p.212). 
A costa peruana era rica em fauna ictiológica, e os pescadores que viviam organizados em ayllus perto do litoral dedicavam-se somente à pesca. ${ }^{13}$

Os pescadores não possuíam terrenos agrícolas, mas cultivavam em lagos a totora para confeccionar seus barcos. Quando tinham peixe em grande quantidade, salgavam e secavam-no para conservá-lo e trocá-lo por produtos da serra.

O hatun runa, "hombre basto, o labrador mitayoc o aldeano que no es de la ciudad" (Holguin, 1989, p.155), era o homem casado que conformava a grande maioria da população andina. Os hatun runa representavam a força de trabalho do Tahuantinsuyu, pois eles trabalhavam os campos, eram recrutados para o exército inca e compunham os grupos de mitmaqs e yanas. ${ }^{14}$

Entre os hatun runa só era permitida a monogamia. O chefe da família cuidava de suas atividades junto à comunidade e ao Estado. Sua esposa tratava dos afazeres domésticos, cuidava dos animais, tecia e criava os filhos. Os jovens costumavam tomar conta do gado da comunidade ou do Estado e podiam ser escolhidos para ser mensageiros, os chasquis. As adolescentes ajudavam as mães, casavam-se com jovens da comunidade ou eram escolhidas para integrar-se às aclla huasi. As crianças também trabalhavam realizando tarefas mais leves.

O trabalho era muito importante no mundo andino, por isso os idosos e aleijados eram considerados pobres, por estarem incapacitados de trabalhar temporária ou indefinidamente, tendo de ser sustentados pelo grupo a que pertenciam. Esse conceito de pobreza

13 "A diferencia de los hábitos europeos, las playas o caletas pertenecían a un determinado ayllu y nadie podía pescar fuera de su propio y conocido territorio. Tenían los pescadores sus turnos o mitas establecidas para entrar al mar, de ahi que sorprendiera a los españoles el número de hombres dedicados a beber o bailar cuando no pescaban" (Canseco, 1978b, p.211-2).

14 "La entrada a la mayoría de edad y a la situación de hatun runa se establecía con el matrimonio. Es entonces que la pareja adquíria su lugar en el ayllu, y junto con ello asumía sus responsabilidades" (Canseco, 1988a, p.218). 
difere do utilizado pelos cronistas espanhóis, que os consideravam pobres porque não tiveram acesso direto à terra e ao pastoreio. ${ }^{15}$

Os mitmaqs compunham grupos que foram transplantados, junto com suas famílias e seu chefe étnico, para outros locais a fim de efetuar tarefas estatais. Por serem de confiança do Inca, costumavam ser enviados para locais fronteiriços com o intuito de facilitar a incorporação de novas regiões ao Tahuantinsuyu.

Os mitmaqs ficavam longe de seu local de origem, mas mantinham os laços de parentesco e de reciprocidade com sua região, o que os diferenciou dos yanas, conforme a afirmação de Canseco (1988a, p.221), pois estes perdiam todos os vínculos com suas origens.

Quando os yanas eram extraídos de seu grupo étnico, passavam a ser criados de curacas, do Inca, das panacas, da coya, esposa principal do Inca, ou mesmo do Sol, pois também trabalhavam no templo do Sol e demais huacas. As acllas eram a parte feminina do grupo de yanas. ${ }^{16}$

As acllas eram as meninas retiradas de seus ayllus e, segundo a justificativa do Inca, selecionadas por sua grande beleza. Na verdade, elas não eram escolhidas por sua formosura, mas por seus dons, principalmente no que concerne à arte têxtil. Ao contrário do que julgaram os espanhóis, as acllas huasis ${ }^{17}$ não eram conventos, mas locais onde se produziam tecidos e chicha, bebida feita à base de milho fermentado. Também serviam como depósito de mulheres para o Inca presentear aqueles a quem devia favores, como regia o sistema de reciprocidade. Nas acllas huasis, também conhecidas como templo das "virgens do Sol", as acllas eram divididas conforme suas origens e aptidões. ${ }^{18}$

15 "De esta manera se nos aclara una vez más el significado prehispánico de la pobreza: el estar físicamente impedido de realizar una actividad para el sustento propio, tanto con respecto a labores personales, como comunitarios" (Gabai, 1980, p.24-5).

16 "Acllacuna. Las mujeres religiosas que estavan en recogimento escogidas para el servicio de su Dios el Sol [...]”" (Holguin, 1989, p.15).

17 Aclla huasi: "casa de escogidas" (Canseco, 1988a, p.293).

18 " [...] yurac aclla, siempre de sangre inca y consagradas al culto, siendo una de ellas considerada como la esposa del Sol. Seguíam las huayrur aclla, generalmente 
As acllas de sangue inca permaneciam castas e reclusas na aclla huasi, mas as outras podiam entrar e sair durante o dia e casar-se quando o Inca desejasse.

Os prisioneiros de guerra que não admitiam a derrota eram transformados em piña e tornavam-se criados do Inca. Canseco (1988a, p.227) questiona se foram eles que deram origem à criação dos yanas, mas Soriano (1990, p.293) afirma que os piñas eram escravos. Existem ainda controvérsias em torno desse assunto, mas convém salientar que os piñas, escravos ou não, representavam a última escala social do Tahuantinsuyu.

A análise da composição social incaica permite-nos perceber que o Estado inca não chegou a integrar-se verdadeiramente. A reciprocidade que formou o Tahuantinsuyu não conseguiu unificar o povo por meio de sentimentos, porque a coerção também foi utilizada, obrigando, por vezes, ao deslocamento maciço de etnias para atender aos preceitos estatais. ${ }^{19}$ Essa situação se refletirá no período colonial quando muitos índios se tornam aliados dos espanhóis para libertar-se do domínio inca.

\section{Economia do Tahuantinsuyu}

A organização econômica do Tahuantinsuyu, como já vimos, baseava-se no funcionamento dos sistemas de reciprocidade e redistribuição. A reciprocidade dava-se dentro dos grupos de parentes-

las más hermosas muchachas y de entre ellas el Inca escogía a sus esposas secundarias. Las paco aclla se convertían con el tiempo en las esposas de los curacas y jefes a quienes el Inca quería agradar; las yana aclla eran las muchachas que no destacaban por su rango, ni por su belleza y cumplian las funciones de servidoras de las demás. [...] las taqui aclla, elegidas por sus aptitudes de cantoras, ellas tañian tambores y pincullo alegrando las fiestas de la corte" (ibidem, p.227).

19 "[... Los ayllus se cohesionaban en torno a sus propias huacas, a sus señores, con ellos se identificaban los hombres del común y no con los grandes, lejanos y temibles soberanos" (ibidem, p.233). 
co, ou seja, quando indivíduos de ayllus intercambiavam produtos e serviços. ${ }^{20}$

Na reciprocidade entre curacas e a coletividade étnica, realizavam-se trabalhos como oferendas às huacas (divindades protetoras) e aos mallquis, que eram as múmias dos antepassados reais. ${ }^{21}$

A redistribuição ocorria entre as comunidades étnicas e o Estado inca, que exigia trabalho como tributo e em troca entregava benefícios coletivos ou individuais. Esse trabalho era conhecido por mita. ${ }^{22}$ Conforme as palavras de Nathan Wachtel (1976a, p.97), podemos concluir que, na sociedade inca, a reciprocidade caracteriza a vida econômica das comunidades rurais e que a redistribuição provém da organização estatal.

A organização desses sistemas de reciprocidade dividiu as populações em "Wamanis, waranquas, llactas, pachacas y ayllus, que en correspondencias más o menos semejantes pueden ser entendidas como provincias, etnias, pueblos, clanes y familias extendidas, respectivamente" (Silva-Santisteban, 1994, p.308). As llactas, as pachacas e os ayllus encontravam-se organizados em metades para facilitar a reciprocidade. Esse sistema dual facilitou a organização da economia incaica, pois as llactas estavam divididas em hanan (de cima) e hurin (de baixo) e em allauca (direita) e ichoc (esquerda), o que beneficiava a distribuição das funções produtivas.

20 "La reciprocidad se ejercía, entonces, a través de la mutua prestación de energía humana para la producción comunitaria; a esto llamaron los cronistas ayni, considerándolo como una suerte de ayuda mutua y no como la obligación que era, originada en los lazos del parentesco" (Pease, 1992a, p.60).

21 "A este tipo de tarea corresponde lo que en la época de los incas se denominaba minka, forma que aún se usa en las comunidades andinas para llevar cabo obras de bien común" (Silva-Santisteban, 1994, p.307).

22 "La mita o prestación de servicios rotativa es un concepto muy andino que se empleó para efectuar trabajos ordenados cíclicamente en un determinado momento. Toda obra contenía la idea de mita, de repetición a su tiempo, de ahí que trabajos muy diferentes fuesen ejecutados bajo el sistema de prestaciones rotativas" (Canseco, 1988a, p.237). Ver também LaVega (1991, p.261), Ondegardo (1990, p.63) e Cieza de León (1991, p.147-8). 
A inexistência de dinheiro e comércio no mundo andino foi substituída pela reciprocidade e redistribuição que ajudaram a organizar a economia e a estrutura social incaica. Conforme afirma Billie Jean Isbell (1974, p.113), "la reciprocidad es el 'hilo' que mantiene unidos: parentesco, jerarquía social y cosmovisión”. Completamos essa ideia salientando mais uma vez a importância da reciprocidade na estruturação econômica incaica, porque foi por meio desse sistema que os incas conseguiram expandir seu território e formar o Tahuantinsuyu.

A terra era o elemento mais importante para a população andina, mas, durante o domínio inca, foi repartida em terra do Inca, do Sol e do povo. De acordo com Blas Valera (apud La Vega, 1991, v.I, p.4068), a propriedade se justificava pelo trabalho comum e particular que havia de ser empregado para plantar. Por isso, era tão grande o apego à terra.

A terra do Inca era trabalhada pelo povo em sistema de mita e a produção servia para abastecer os depósitos administrativos, também chamados de tambos. Esses produtos eram utilizados para sustentar a elite, os exércitos e o excedente faziam parte dos bens a serem redistribuídos. O serviço rotativo prestado pelos camponeses, a mita, também foi utilizado para efetuar as tarefas produtivas na terra do Sol. ${ }^{23}$

O hatun runa ou homem comum, ao casar-se, recebia um tupu para o sustento de sua família. Canseco (1993, p.178), num estudo sobre os sistemas de medições no mundo andino, concluiu que um tupu foi o lote de terra suficiente para a subsistência de um casal sem filhos.

O Estado inca dividia, dessa maneira, a terra destinada à população do Tahuantinsuyu. Cada família recebia seu pedaço de terra para plantar e criar animais, tirando daí o seu sustento. O tamanho

23 "Las tierras eclesiásticas se cultivaban para cosechar maíz y posiblemente otros productos para los sacrificios, así como para alimentar un elevado número de sacerdotes, las aclla y otros religiosos" (Murra, 1983, p.71). 
da área territorial que o Estado tomava para si de cada grupo étnico variava, pois, de acordo com as palavras de Ondegardo (1916, p.58), isso se dava em conformidade com a natureza das terras e de sua população. As terras dedicadas ao culto eram cultivadas e administradas separadamente, e o produto da colheita, armazenado em depósitos próprios.

Quanto ao direito à terra, havia uma hierarquia a ser respeitada, articulada ao sistema de parentesco que determinava as terras a serem distribuídas de acordo com cada unidade doméstica. Os direitos dos curacas podiam estar articulados à sua ancestralidade ou ainda ser oriundos de recompensas oferecidas pelos chefes incas, como demonstra Ondegardo (1916, p.67): “[... esta propriedad no la podia tener sino fuese por merçed Del ynga la qual haçia algunas vezes por servicios que le haçian [...]".

Não sabemos se essas terras doadas pertenciam aos domínios estatais ou aos grupos locais, mas era certo que fossem produzidas pela linhagem daquele que as recebia, compartilhando assim da colheita. O Estado inca não apenas concedia terras, mas também as tomava no caso de rebeliões, pois a perda dos meios de subsistência era o pior dos castigos. Os cronistas sempre confundiram as terras incas com as estatais. As primeiras eram cultivadas para subsistência dos chefes incas e sua parentela e também para as múmias e seus servidores (ibidem, p.134-6), e as estatais para manutenção do exército e do sistema de reciprocidade e redistribuição.

Em suma, para nossa pesquisa é importante entender que o direito à terra nos Andes estava relacionado com o sistema de parentesco, ou seja, todo grupo ligado por consanguinidade a um determinado curaca possuía suas próprias terras de cultivo, seus pastos e suas reservas de água. As fronteiras dessas terras eram conhecidas por todos e, em geral, estavam representadas por montanhas, rios e outras barreiras naturais. Porém, havia ayllus que possuíam terras dispersas entre as montanhas e a costa, até mesmo para ter acesso a produtos de regiões diferentes. Percebemos, então, que a concepção de território nos Andes possui muitas particularidades. Para exemplificar, temos o caso dos ayllus de Acari, que tinham suas terras 
dispersas não apenas no Vale de Acari, como também no vale vizinho de Yauca (Visita de Acari, 1973).

Na serra meridional, o sistema de enclaves significou o domínio dos senhores étnicos serranos sobre os habitantes do litoral e até mesmo da selva. Essa descontinuidade territorial foi mais comum na serra por haver mais espaço disponível, já que os vales da costa peruana estavam entrecortados por desertos. Outro exemplo desse sistema de domínio territorial encontramos na Visita de Cajamarca de 1571 -1572. O senhorio de Cajamarca era uma macroetnia que possuía cinquenta e duas pachacas, termo que parece ser sinônimo de ayllu na região norte da serra (Canseco, 1981, p.39; Soriano, 1981, p.114). Cada pachaca possuía seu território disperso e entrelaçado com territórios de outros grupos. Longe da concepção europeia de fronteira, essa distribuição atendia à necessidade de diminuição dos riscos na agricultura andina, que estava sujeita a granizo, pragas, secas ou excesso de chuva. Assim, se perdessem uma colheita, teriam acesso a outras e nunca ficariam desprovidos de sustento (Canseco, 1992).

Sendo a agricultura a base da economia incaica, foram desenvolvidas técnicas que aumentaram a produtividade dos campos. Os andenes ou terraços agrícolas artificiais já eram conhecidos por povos pré-incaicos, mas foram utilizados em larga escala pelos incas, pois permitiam uma grande produção agrícola.

John Murra (1975, p.59-115) desenvolveu a hipótese de que as sociedades andinas puderam aumentar sua produção por meio do controle vertical de um máximo de pisos ecológicos, pois podiam obter produtos da costa e da serra sem que fosse necessário afastar-se por muito tempo de seu lugar de origem. Os incas desenvolveram diversas técnicas de irrigação que beneficiavam o regadio dos locais de plantio. Para adubar a terra, utilizaram esterco de lhama ou alpaca, na serra, e na costa o guano (esterco de aves) e cabeças de peixe.

O transporte dos produtos agrícolas era feito por animais, como a lhama, pelas estradas que ligavam todos os pontos do Tahuantinsuyu. Ao longo dos caminhos, havia locais de descanso, os tambos, que, além de servirem para o armazenamento de produtos, também eram um tipo de pousada. 
Para controlar a produção no Tahuantinsuyu, os incas utilizavam o quipu.

El quipu consta de una cuerda principal - sin nudos - de la cual se desprenden otras, generalmente anudadas, y de diversos colores, formas y tamaños [...] En los tiempos de los incas los quipus fueron utilizados así para fines contables [...] (Pease, 1992a, p.100)

A criação de gado também foi de grande importância para a economia inca. Criavam-se, principalmente, lhamas e alpacas, além de outros animais de menor porte. A carne da lhama, quando animal velho, era transformada em charque, o qual se conservava por muito tempo. Mas a principal utilidade da lhama era servir como animal de carga. Sua lã também era aproveitada para confeccionar tecidos. Da alpaca, aproveitavam-se a lã e a carne, que era muito consumida. Os rebanhos do Inca e do Sol destinavam-se à redistribuição, enquanto os das comunidades serviam para a subsistência do próprio grupo.

Os incas dedicavam-se também à mineração, principalmente de ouro e prata. Assim como existia a mita têxtil para produzir tecido em grande quantidade, também havia a mita mineira, quando um determinado número de pessoas era levado aos locais de extração para trabalhar em prol do Estado. Os metais preciosos eram levados para Cuzco para serem armazenados nos depósitos estatais, utilizados como decoração ou redistribuídos pelo Inca.

A redistribuição, ao contrário do que possa parecer, não ocorria porque o Estado tinha fins humanitários, e sim porque este necessitava de excedentes para investir na reciprocidade que garantia o domínio inca sobre as demais etnias. John Murra (1975, p.42) argumenta:

[...] la redistribución tiene poco que ver con "economías de bienestar". La mayor parte de lo almacenado se gastaba e invertía allí donde la autoridad creía más conveniente. En este sentido, el Estado Inca funcionaba como un mercado: absorvía la productividad "excedente" de una población autosuficiente y "trocaba" este excedente en la alimentación del ejército, 
de quienes servían en la "mita" o en la de la familia imperial, tratando, de paso, de ganarse la lealtad de los beneficiados.

Como vimos, a reciprocidade ocorria por meio das prestações de serviço em âmbito comunitário, ayni e minka, e a redistribuição baseava-se na mita. Esses sistemas regiam a economia incaica, porém havia diferenças entre os modelos econômicos da serra e da costa.

La existencia de estos dos modelos de organización tan distintos, el costeño y el serrano, pueden sugerir el hecho que en el área andina precolombina hubo dos sistemas socio-económicos debido en parte a las diferencias ecológicas. En la costa la división laboral por oficios y por parcialidad dio lugar a un pincipio de intercambio comercial, mientras en la sierra una economía agrícola de tipo redistributivo estuvo basada en una explotación de enclaves verticales multiétnicos. (Canseco, 1977, p.19)

Quando o Tahuantinsuyu se formou, foi indispensável contar com a força de trabalho dos diversos grupos étnicos anexados aos domínios incas pela reciprocidade. A posse da terra centralizou o poder na figura do Inca, o que propiciou o controle de toda a produção necessária para a redistribuição. Dessa maneira, as bases da economia incaica, a reciprocidade e a redistribuição prosseguiram funcionando tanto nos ayllus como em relação ao Estado, beneficiando, em parte, a integração do território inca, já que algumas etnias prosseguiram insatisfeitas ante o domínio incaico.

\section{Realidade e ficção: a conquista do Peru nas crônicas}

Depois de termos conhecido um pouco do mundo pré-hispânico, passaremos a analisar crônicas que nos fornecem imagens da conquista espanhola. Como crônicas são uma mescla de história e literatura, de verdade e mentira, de realidade e ficção, temos então um material de difícil manejo, em razão dessa fina linha que separa o mundo real do imaginário. 
Quando tratamos de rever a história da conquista do Peru à luz de algumas crônicas escritas nos séculos XVI e XVII, sabemos que os homens que as redigiram estavam no preâmbulo da idades Média e Moderna, e que possuíam uma série de modelos de respeito às normas locais de autoridade e às ortodoxias doutrinais, bem como uma predisposição ao novo e à aventura, própria de uma consciência moderna (Durand, 1953). Sendo assim, seus escritos eram o resultado de uma mescla de informações culturais. Isso se estende aos cronistas indígenas e mestiços, já que eram homens que passaram pelo processo de aculturação.

Ao cruzarem o Atlântico, esses homens envoltos de características mentais do medievo europeu conjecturaram sobre o novo espaço territorial encontrado, e houve quem concluísse que a América era a continuação das Índias orientais.

Las Casas (1958) tentou provar isso, argumentando que a fertilidade e felicidade encontradas nesse novo espaço eram semelhantes às que existiam na verdadeira Índia, conforme o escrito de antigos historiadores. Segundo Las Casas, San Isidoro no livro XIV, 3oapítulo das Etimologias, relatou que a Índia era terra muito fértil, com muita gente, árvores que nunca perdiam as folhas e que davam frutos duas vezes ao ano e que abundava em metais e pedras preciosas, sendo essas características encontradas no novo continente.

Tentando entender esse mundo desconhecido, houve quem procurasse explicar a presença humana na América de modo coerente, como o fez Acosta (1954), especialmente no que diz respeito ao Peru. Para ele, essa gente chegou por mar ou terra, por acaso ou por determinação própria, e não em cavalo com asas, como cogitaram os apreciadores de fábulas.

\section{A conquista}

Francisco Pizarro e Diego de Almagro, acompanhados de 350 soldados, saíram da Espanha em busca das Índias, de ouro, prata e de todas as riquezas que se poderiam encontrar nessas novas para- 
gens. Não tiveram medo, envolvidos que estavam pelo sonho de adquirir ouro e prata (Ayala, 1993, p.284).

Aventurando sus vidas

Han hecho lo no pensado,

Hallar lo nunca hallado,

Ganar tierras no sabidas,

Enriquecer nuestro Estado.

Ganaros tantas partidas

De gentes antes no oídas,

Y también, como se ha visto,

Hacer convertirse a Cristo

Tantas ánimas perdidas. (Xerez, 1985, p.162)

Ao contrário dos espanhóis, os habitantes do Tahuantinsuyu não se regozijaram com a chegada desses homens ambiciosos. Antes desse nefasto momento, já os feiticeiros e sacerdotes haviam visto, nas entranhas de animais sacrificados, que coisas terríveis estavam por acontecer. Quando Huayna Capac estava em Quito, recebeu a informação de que havia perto de Tumbez monstros marinhos e homens com barbas, que andavam no mar em grandes casas (Montesinos, 1882).

Houve também quem dissesse que eram viracochas, ${ }^{24}$ homens de barbas negras ou ruivas e de belos trajes que se locomoviam em grandes animais com pés de prata (Yupanqui, 1992). Certo é que tais homens deuses ou monstros foram os responsáveis pelo massacre de grande parte da população andina.

O encontro de Pizarro com Atahualpa em 1532 começou com uma tentativa de reciprocidade, tão conhecida pelos incas, e terminou em guerra. O motivo para o início da batalha sangrenta, segundo Xerez (1985, p.112-3), foi o fato de Atahualpa ter jogado a Bíblia sagrada ao chão. Ofendido, o frei Vicente Valverde queixou-se a Pizarro, que imediatamente ordenou o ataque. Atahualpa foi pron- 
tamente capturado e o alvoroço foi tremendo, índios correram para todos os lados, fugindo dos tiros de arcabuzes e das patas dos cavalos, e outros ficaram paralisados pelo terror. A grande maioria das pessoas que se encontrava na praça de Cajamarca pereceu aí mesmo. Pizarro solicitou um resgate imensurável pela liberdade de Atahualpa, resolveu condená-lo à morte, mesmo depois de ter recebido todo o montante de ouro e prata que havia exigido.

Atahualpa, sabendo de sua sentença, roga a Pizarro por sua vida.

Me maravillo de ti, oh capitán, que, porque habiéndome prometido por tu fe y dándote el rescate prometido, no solamente me quitarías las cadenas y me pondrías en libertad, sino que abandonarias mi país, ahora, cuando has conseguido el rescate prometido por mi libertad, me has sentenciado a muerte. Si Filippillo ${ }^{25}$ te ha dicho que he tramado mataros a los barbudos, no ha dicho la verdad, porque nunca llegue a pensar tal cosa.Te ruego, pues, que me dejes vivir, porque contra ti nunca he pensado ni cometido nada que me haga merecedor de la muerte. Y si no te fías de mí, envíame a España ante el Emperador, a quien ofreceré gran cantidad de oro y de plata. Si, por el contrario, me matas, te aseguro que mis vasallos eligirán otro Rey que os matará a todos los barbudos. Manteniendome con vida, sin embargo governaré el país en paz y no habrá nadie que se atreva a moverse. (Benzoni, 1989, p.251-2)

O pedido de Atahualpa não foi levado em conta, pois Pizarro estava resolvido a solucionar todos os seus problemas, pondo fim à vida do inca. Atahualpa foi retirado da prisão e, ao som de trompetas, levado para a praça, onde o amarraram a um pau. Enquanto isso, um religioso ia consolando-o e predicando-lhe, por meio de um intérprete, os ensinamentos da fé cristã. Estando ele condenado a morrer na fogueira, nos últimos instantes pediu para ser batizado, a que foi prontamente atendido, e, por isso, conseguiu morrer garroteado, livrando-se de ser queimado vivo. Mesmo assim, depois de cumprida a sentença, ainda atiraram fogo à roupa para que se queimasse

25 Intérprete indígena e confidente dos espanhóis, símbolo da traição à raça. 
também parte da carne. Seu enterro foi assistido por Pizarro e seus companheiros, com direito a cruz e demais aparatos religiosos cristãos, sendo por fim enterrado numa igreja, como verdadeiro espanhol (Hoz, 1986, p.68).

$\mathrm{O}$ assassinato de Atahualpa significou a desestruturação ${ }^{26}$ do mundo andino e a conquista espanhola, em termos gerais, demonstrou como a falta de conhecimento do outro pode gerar um desencontro cultural de consequências desastrosas.

A derrota incaica ante tão poucos espanhóis até hoje é difícil de ser explicada. As descrições do massacre ocorrido em Cajamarca nos mostram a debilidade de milhares de homens diante de alguns cavalos, tiros de arcabuzes e coisas aterrorizantes para quem nunca tinha lutado dessa maneira. Por mais que consideremos esses dados, nãoé possível entender essa indescritível carnificina.

Explicações possíveis para tal tragédia podem estar relacionadas com o fato de os espanhóis não terem atacado desde o princípio, pois fizeram o que para os incas era usual, estabeleceram um sistema de reciprocidade, mediante a troca de presentes e mercadorias diversas. Portanto, estabelecido esse sistema e não tendo sido atacados, não haveria motivo para se prevenir contra os espanhóis, logo o fator surpresa foi contundente.

Em relação ao momento exato do ataque, em que milhares de índios atordoados diante do aprisionamento de seu chefe sucumbiram quase sem reação, cremos que a verticalidade do Tahuantinsuyu seja um dos fatores de tal apatia diante do perigo. Para os incas, o seu chefe era como um deus e, portanto, o responsável por todos os atos e todas as aspirações. Desprovidos de seu deus, esses homens ficaram absolutamente perdidos, pois não estavam acostumados a tomar iniciativas individuais.

26 “[...] por el término de 'desestruturación' entendemos la supervivencia de estructuras antiguas o de elementos parciales de ellas, pero fuera del contexto relativamente coherente en el cual se situaban [...]" (Wachtel, 1976a, p.135). 


\section{4 \\ A REPRESENTAÇÃO DO AYLLU PRÉ-HISPÂNICO E COLONIAL EM CRÔNICAS QUINHENTISTAS}

No capítulo anterior, abordamos alguns dados da história dos incas para facilitar a compreensão de nosso objeto de estudo. Analisar o ayllu em crônicas quinhentistas buscando as diversas interpretações a ele atribuídas, bem como as transformações ocorridas do período pré-hispânico ao toledano, pressupõe a necessidade de conhecermos o significado dessa estrutura entre os pesquisadores contemporâneos. Para tal, analisamos alguns estudos de historiadores, antropólogos e etno-historiadores.

\section{O ayllu: simbologia de um povo}

Algumas interpretações dadas ao ayllu no período pré-hispânico, históricas ou antropológicas, atribuem-lhe o sentido de sistema de parentesco, família extensa, linhagem, clã etc. Outros estudos referem-se ao ayllu com uma conotação territorial, e essa interpretação só é possível a partir do século XVI quando cronistas espanhóis propagam o termo com uma acepção de agrupamento de índios ou pueblo.

O ayllu pré-hispânico é a família extensa que forma um grupo local detentor ou não de um território utilizado comunitariamente 
para subsistência de seus integrantes. Sendo assim, o ayllu não é o território, a aldeia, mas o grupo familiar que está ligado por laços de parentesco e reciprocidade produtiva.

O precursor dos estudos sobre ayllu foi Heinrich Cunow (1929a, 1929b, 1933), que escreveu três obras sobre o assunto no final do século XIX. O autor discorreu sobre o parentesco, a comunidade e a organização social entre os incas, vislumbrando a presença do ayllu como um dos problemas fundamentais para o conhecimento do mundo andino.

Partindo da definição da marca ${ }^{1}$ germânica, procurou encontrar semelhanças com o ayllu andino descrito pelos cronistas. A partir desse estudo, Cunow (1933, p.37) interpretou o ayllu como uma comunidade que tinha seu próprio campo de cultivo, igual ao modelo das reduções de Toledo.

La base de la antigua organización social fue el ayllu o pachaca que, al mismo tiempo, constituía, generalmente, una población o aldea, teniendo como propiedad, una parte de la tierra de la tribu. Tal distrito de la pachaca se llamó Marca.

Essa identificação entre o conceito de ayllu, marca e território originou confusões que persistiram em nossos dias, pelo fato de alguns cronistas do século XVI terem estabelecido uma relação entre ayllu e as reduções toledanas (Matienzo, 1967; Acosta, 1954).

La voz ayllu era el nombre común dado originalmente a un grupo de parientes consaguíneos. Estos individuos en conjunto se llamaban ayllucuna o ayllupura. Solamente después de la conquista, los españoles dieron al vocablo el significado geográfico que se llegó a tener para hablar del territorio ocupado por el grupo de parientes. (Latcham, 1928, p.161)

1 Marca: “[...] la marca no tuvo su origen, según se pensó antes, en una aglomeración de casas aisladas en los primeros tiempos, sino que se formó mediante agrupaciones de comunidades gentilicias" (Cunow, 1929b, p.13). 
Conforme Franklin Pease (1981, p.21), da concepção de ayllu tida por Matienzo (1967) originou-se a ideia de identificá-lo com comunidade, ideia que foi propagada por Cunow e que fez escola, sendo seguida por Castro Pozo e Mariátegui.

Castro Pozo (1924, 1963, 1973) e Mariátegui (1975) foram representantes significativos do movimento indigenista peruano dos anos 30, que tinha por objetivo a reflexão em torno dos problemas que afetavam a população indígena. Esses autores basearam suas análises no estudo do ayllu como organização comunal indígena, tendo por intuito fazer prevalecer o direito à terra dessas comunidades.

Castro Pozo (1973), em sua obra Del ayllu al cooperativismo socialista, elaborou um ensaio sobre o desenvolvimento das comunidades durante os períodos pré-hispânico, colonial e republicano, verificando a transformação ocorrida nesse período. Depois de expor a origem e funcionamento do ayllu e sua evolução, propôs que as comunidades fossem transformadas em cooperativas de produção indígena.

Lo que debemos aprovechar del ayllu no son precisamente, sus prácticas geneonómicas, ni el sentido doliente o pesimista de la vida; tampoco su espíritu gregario, supersticioso o misoneísta, forjado en el yunque de la esclavitud, el alcoholismo y el despojo violento de sus tierras durante varios siglos. Lo que debemos aprovechar del ayllu es su unidad económico-moral: tierras de usufructuación colectiva, cooperación de brazos y de intención y voluntad en la producción socializada; factores de orden económico y espiritual, que quienquiera se jacte de conocer el ayllu peruano no se atreverá a negarlos como caracteres idiosincráticos de aquél.

$Y$ así, concretando el problema a este plano, cabe preguntarse: Es tan disímil la comunidad de una institución cooperativa proletaria dedicada a la producción? (Castro Pozo, 1973, p.209-10)

Seguindo a visão tida por Castro Pozo sobre o ayllu, Mariátegui (1975) também fundamentou suas ideias na identificação dessa estrutura com comunidade. Em Sete ensaios de interpretação da realidade peruana, Mariátegui (1975) aplicou o sistema marxista à história do Peru. Traçou um quadro evolutivo da economia da sociedade 
peruana, partindo do estudo do incário. Discorreu sobre o problema do índio e da terra: "A questão indígena emerge de nossa economia. Suas raízes estão no regime de propriedade da terra" (ibidem, p.21).

Partindo desse ponto, Mariátegui (1975, p.23) fez sua defesa em prol das comunidades indígenas, indo contra o latifundiário, que, segundo ele, era "um senhor feudal".

A comunidade representava um fator natural de socialização da terra, e, como o índio tinha hábitos arraigados de cooperação, a comunidade poderia transformar-se em cooperativa (ibidem, p.72). Dessa forma, suas diretrizes teóricas convergiam numa visão territorial da organização comunal, pois analisou a evolução da propriedade com base nos princípios de latifúndio e comunidade.

Castro Pozo e Mariátegui recorreram ao passado incaico para elaborar seus estudos, que tinham como cerne a importância do trabalho comunal entre os indígenas, que, em tempos idos, era encontrado na organização interna do ayllu. Com isso, defenderam os direitos indígenas, porém as relações de parentesco foram substituídas em importância pelo sentido comunitário do ayllu.

Historiadores e antropólogos dedicaram-se à análise do significado do ayllu, estendendo-se até os dias atuais, para compreender como se formaram as comunidades indígenas de hoje.

José María Arguedas (1968), em sua tese de doutorado, afirmou que a comunidade de indígenas contemporânea era uma consequência da colonização. Para comprovar isso, procurou em antigas comunidades espanholas sobrevivências de vida comunal.

[...] el buen conocimiento de esas supervivencias y de sus fundamentos históricos iluminarían la historia y la realidad actual de la organización y funcionamento de nuestras comunidades, los que sus instituciones representan como productos del pasado y como partes integrantes de nuestra actual e intrincada composición social. (Arguedas, 1968, p.7)

Arguedas (1968, p.9) pautou algumas perguntas sobre as consequências da política colonial: 
$[\ldots]_{¿} Q u e ́$ elementos de la organización de las comunidades de Castilla tomó, principalmente Toledo, en su política de organizar las poblaciones de indios con vistas a su aprovechamiento para la economía real y a evitar que fueran explotados únicamente en beneficio de los encomenderos? ¿Y cómo los encomenderos, a su vez, trataron de hacer frente a esta política y torcieron a su favor las instituciones montadas por la administración real para la explotación de la masa de índios?

Essas interrogativas levaram à conclusão de que o peso histórico das reduções toledanas foi determinante na vida das comunidades andinas.

Depois, foi a vez de Fernando Fuenzalida Vollmar (1976, p.244) abordar a ideia de a comunidade indígena ter tido sua origem no período colonial, e a estrutura de parentesco representada pelo ayllu teria se transformado em cofradía, que juntava os laços parentais com os rituais do cristianismo:

[...] En la medida en que he tenido oportunidad de trabajar en comunidades en las que, a pesar de la modernización, alguna evidencia del antiguo sistema de cofradías era visible todavía, he sido conducido al convencimiento de que es ahí en donde la articulación interna del ayllu debe ser estudiada.

A relação ayllu/cofradía também foi analisada por Celestino \& Meyers (1981, p.303):

Tentativamente, tenemos la impresión de que hay una correspondencia estrecha entre los ayllus y la cofradía. Al instalarse varias cofradías en el interior de una reducción desarrollan y albergan las solidaridades étnicas y parentales. Simultáneamente, se apela a la cofradía con el nombre del ayllu o al ayllu con el nombre de la cofradía.

José Matos Mar (1976b, p.182) resgatou a noção de ayllu ligada à concepção de comunidade, mostrando que

[...] dos fueron las vías más importantes de constitución de la comunidad. En un caso las reducciones y en otro la evolución de los propios ayllus. 
Derroteros ambos condicionados a su vez por los enclaves mineros y por el desarrolo del sistema de hacienda. Aparece claro que la vía de la reducción fue la más común, pero no se puede soslayar que existieron regiones enteras del Perú donde la hacienda no se desarroló sino tardíamente, la minería no fue importante y que no fueron alcanzadas drásticamente por el aparato administrativo colonial, lo que se refleja en la ausencia de ciudades españolas; factores todos que permitieron una relativa autonomía al desarrollo del ayllu que, sin embargo, finalmente, no pudo escapar del influjo colonial convirtiéndose por vía propia en comunidad.

Essa tese nos faz reafirmar que a identidade territorial do ayllu ficou estabelecida nas reduções toledanas quando foi convertido em um espaço físico ou comunidade.

Diversos pesquisadores elaboraram seus conceitos de ayllu, uns baseando-se nas crônicas e outros em dados antropológicos recolhidos atualmente junto aos grupos indígenas.

John Rowe (1963) chamou atenção para o fato de que utilizar crônicas para definir a natureza dos ayllus é uma tarefa difícil, por causa da terminologia do vocábulo quechua. Em castelhano, essa palavra adquiriu diversas conotações: linhagem dos soberanos incas, família extensa ou parcialidade. E conclui: "[... the Inca ayllu was a kin group with theoretical endogamy, with descent in the male line, and without totemism" (ibidem, p.255).

Para Tom Zuidema (1991, p.38), ayllu era uma unidade política e social, um grupo de parentesco, e até mesmo representava a noção de "parente". Waldemar Espinoza Soriano (1981, p.101) considerou o ayllu um clã, cujos membros podiam viver em um só território ou distribuídos em vários, mas sempre formando um grupo consanguíneo. Para ele, o ayllu andino correspondia ao que se chama hoje comunidade aldeã.

Os conceitos apresentados diferem em particularidades, mas o consenso entre os especialistas é claro, o ayllu representa um grupo de parentesco.

Irene Silverblatt (1990), antropóloga marxista, realizou uma pesquisa sobre o povo inca, em que analisou o papel da mulher nessa 
sociedade com base nas relações de parentesco para entender a dinâmica do Estado incaico. Para essa pesquisadora, o ayllu era uma família extensa ou um grupo político "étnico" local, detentor dos recursos produtivos que formavam a base da sua subsistência. Porém, Silverblatt (1990, p.1606) afirmou ser errôneo considerar as relações sociais de produção do Estado inca fundamentadas nas relações de parentesco. Para essa autora, essas relações estavam baseadas em relações produtivas ditadas pelas estruturas político-religiosas dominadas por Cuzco.

O estudo da representação de ayllu requer um conhecimento das crônicas e do contexto em que foram escritas, pois estas nos fornecem elementos que, comparados com outros dados históricos e com os resultados de estudos antropológicos junto a grupos indígenas, poder-nos-ão proporcionar um entendimento dessa estrutura.

A problematização inicial em que alguns autores partiram da premissa de que o ayllu era a "marca" ou território pode ser compreendida na medida em que sabemos que essa ideia se originou na concepção reducional de Juan de Matienzo (1967).

O movimento indigenista peruano utilizou ideologicamente essa concepção de ayllu como organização comunal detentora de um território para defender os direitos de os indígenas terem garantido o acesso à terra. Nesse caso, não importavam as relações de parentesco, mas, sim, a comunidade que se podia transformar numa cooperativa, na qual todos produziriam para o bem do grupo.

Porém, pesquisadores de áreas distintas analisaram crônicas, documentos administrativos e eclesiásticos, realizaram estudos junto a comunidades indígenas existentes nos enclaves andinos atuais e chegaram à conclusão de que o ayllu pré-hispânico teve um significado diferente da estrutura comunitária existente no período colonial.

Antes da chegada dos espanhóis, o ayllu era um grupo ligado por laços de consanguinidade e, no período colonial, com as reduções de Toledo, transformou-se numa aldeia onde poderiam estar reagrupados vários ayllus. Dessa mudança, dizem os pesquisadores, surgiu a comunidade indígena contemporânea. Não nos alongaremos nessa discussão, pois não é nosso tema de estudo, mas a repre- 
sentação do ayllu pré-hispânico e colonial encontrada em crônicas quinhentistas.

\section{A cultura dos cronistas}

Os pesquisadores que trabalham com sociedades indígenas centram sua atenção em documentos do tipo jurídico-administrativo (visitas, testamentos, processos) ou em relações e informes, e têm deixado em segundo plano as crônicas. Quando as utilizam, dão maior importância àquelas que foram escritas primeiro e que têm caráter menos teórico e intelectualizado, por acharem que estas podem oferecer informações menos deformadas. Contrariamos esse posicionamento, pois as crônicas são importantes fontes etnográficas, independentemente de serem contemporâneas ao momento da conquista ou de terem sido redigidas em período posterior. $\mathrm{O}$ fato de seus autores serem verdadeiros humanistas ou pouco letrados não desvaloriza o conteúdo dessas crônicas. A importância desses estudos para a história e para a antropologia foi expressa por Elliot (1997, p.19) quando incentivou o prosseguimento desse tipo de pesquisa, salientando que esses textos podem proporcionar dados de interesse sobre a sociedade europeia, suas ideias, atitudes e preconceitos, ou seja, saber o que viram e por que agiram da forma como o fizeram.

Para estudarmos o ayllu por meio das crônicas, precisamos antes de tudo saber quem eram as pessoas que vieram para a América e ocuparam seu tempo redigindo obras, por vezes monumentais, sobre o Novo Mundo, os grupos étnicos que aqui habitavam e as façanhas dos conquistadores. Assim, adentraremos no ambiente social e cultural da primeira metade do século XVI.

Se nos reportarmos à Espanha desse período, verificaremos que esta vivia o processo humanista, a reforma religiosa e a formação de uma elite de "letrados" a serviço de um Estado moderno em expansão. É no final do século XV que começam surgir as universidades e os diversos pequenos colégios, dando origem a uma verdadeira "re- 
volução educacional". Isso se deve, entre outras coisas, a fatores demográficos e econômicos, à evolução social e política, às mudanças nas oportunidades de emprego, às crenças religiosas, às correntes intelectuais e às atitudes dos adultos em relação às crianças e à sua formação (Kagan, 1981, p.34).

Essa mudança, sem dúvida, se deve principalmente à influência das ideias humanistas e ao seu papel na formação de homens úteis à comunidade. Os humanistas propunham algo mais do que os estudos medievais de teologia e direito, eles estudavam as artes, as humanitates, visando formar verdadeiros cidadãos. A educação para eles era o instrumento básico para conseguir a reforma moral da sociedade, com a qual estavam descontentes. Os humanistas pesquisaram o passado em contraposição ao presente e elegeram os gregos e romanos como exemplos culturais a serem copiados (Maravall, 1966, p.248-60).

Apesar de o grupo humanista ter conseguido despertar o interesse de alguns grupos da sociedade, não atingiu imediatamente as antigas universidades que se preocupavam em formar funcionários públicos. Porém, durante o governo dos reis católicos, surgiu a necessidade de aumentar o aparato burocrático que atendesse às necessidades de um Estado moderno com funcionários que tivessem formação adequada e conhecimentos jurídicos. Isso fez surgir um novo grupo social, o dos "letrados", composto principalmente por juristas provenientes das mais conhecidas universidades (Kagan, 1981, p.124-30). Assim, foi possível que pessoas de origem humilde pudessem ascender socialmente. Esse novo grupo social passou a disputar os mais altos postos com a aristocracia, que até então detinha o poder. A Coroa apoiou a criação de novas universidades e também a Igreja, responsável pela fundação de quase metade das universidades surgidas na Espanha a partir de 1474 (Kagan, 1981, p.110; Queija, 1993, p.15-7).

Esse processo educacional tão forte no século XVI não atingiu todas as pessoas, e, por isso, nossos cronistas representam uma mescla de "letrados" com quase analfabetos. Não podemos esquecer também que a maioria estava fixada na América, onde havia grande di- 
ficuldade em conseguir livros. Mesmo assim, muitos tinham por hábito ler tudo o que lhes chegava às mãos.

Os cronistas tinham por hábito avaliar-se, o que deu origem a três posicionamentos críticos. Uns se achavam de poucas letras, outros, ao contrário, se diziam verdadeiros humanistas, e, por fim, havia aqueles que não expressaram suas opiniões.

Cieza de León (1991, v.I, p.6-14) é um exemplo do primeiro grupo, pois confessa ser homem de cultura bastante discreta.

Fernández de Oviedo (1959, t.I, p.141) também transmite ao leitor uma imagem de iletrado, mesmo tendo estudado e ser conhecedor profundo de uma língua estrangeira, o italiano. Ele diz ter pouca retórica, fundamental para um letrado que queira escrever com graça e ornamento.

Entre os cronistas humanistas, temos Garcilaso de la Vega (1989, p.73-80) que quase nos engana ao solicitar benevolência na leitura de sua obra por ser um índio que domina pouco o castelhano. Longe de ser verdade, La Vega era um grande humanista que estudou em Córdoba e possuiu uma biblioteca invejável. Ele sabia de seu valor e o expressava nas entrelinhas ou como fez nas "Advertencias" da primeira parte dos Comentarios reales, em que apresenta um comentário sobre as crônicas dos espanhóis e nos oferece eruditas notas filológicas sobre o quechua para "atajar la corrupción" que dessa língua haviam iniciado os espanhóis (ibidem, 1991, p.5). O inca "como índio" se propôs a restaurar em sua pureza e propriedade o quechua. Pretensão bastante erudita que contrasta com as palavras prévias sobre sua falta de letras.

Ao contrário de La Vega, Las Casas (1958) se ufana em suas obras de ser grande humanista e prova que a humildade não era uma virtude sua. No "Argumento" da Apologética, afirma que escreve um grande discurso para pessoas de muita capacidade de entendimento.

Em geral, os cronistas tinham dificuldade de descrever seu grau de conhecimento, muitos nem necessitavam fazê-lo, pois escreviam por obrigação burocrática cartas, relações ou diários de conquista, por exemplo. Nesse caso, temos alguns burocratas como Ondegardo 
(1990) e Santillán (1968), que respondem a petições reais por meio de cédulas reais.

Outros não o fazem por distintos motivos. Uns por serem humanistas que não necessitam explicar nada a ninguém, pois têm consciência de que dominam a filosofia e a historiografia, como é o caso de Gómara (1946) e Zárate (1965). O grupo de frades que se dedica à etnografia é de um alto nível cultural, o que os exime da necessidade de explicar sua vocação historiográfica. Eles estavam mais preocupados em descrever os "ritos e costumes" indígenas para poder acelerar o processo de conversão ao cristianismo. Entre tantos outros, destacamos nesse rol Cristóbal de Molina (1959), Juan de Betanzos (1968) e o Jesuita Anónimo (1968). Por último, temos o grupo que escreveu sem que nada lhes tivesse sido solicitado e que se calam em relação aos seus poucos conhecimentos. Estes, em sua maioria conquistadores, escreveram suas memórias idealizadas sobre a aventura da conquista espanhola, como foi o caso de Cristóbal de Mena (1987), Xerez (1985), Diego de Trujillo (1985), Pedro Pizarro (1978) e outros.

Concluímos assim nosso panorama sobre a cultura dos cronistas. Embora fossem provenientes de um ambiente de humanistas, poucos dos que passaram às Índias possuíam grandes conhecimentos. Os humanistas estavam mais interessados em estudos filológicos, jurídicos e teológicos do que compreender o Novo Mundo (Valcácer Martínez, 1997, p.344-54).

\section{Dicionários e questões linguísticas}

As crônicas quinhentistas são relatos de aventuras, conquistas, tragédias, mas antes de tudo são as representações de um tempo que passou. Mergulhando em suas linhas, encontramos pistas daquilo que foi o ayllu no período pré-toledano e toledano. Percebemos, no entanto, que, embora os cronistas tenham se dedicado com afinco aos relatos do que viram, ouviram ou até mesmo a apenas transcrever documentos alheios, eles apenas representaram os acontecimentos 
vividos. Sendo assim, o ayllu por eles descrito é fruto de práticas culturais entre indígenas e espanhóis. Assim, temos, de um lado, representações dessa estrutura aos olhos de nativos e, de outro, uma noção adaptada às necessidades da administração espanhola colonial.

Durante as reduções do final do século XVI, diversos grupos indígenas, antes ligados por laços de parentesco, foram incorporados a esse sistema territorial diferente de sua organização tradicional, e isso foi descrito pelos cronistas. A dificuldade que encontramos ao analisar tais obras começa por uma questão linguística, que, por vezes, gera interpretações múltiplas.

Para compreendermos esse problema, necessitamos recorrer aos léxicos da época para poder comparar os diversos significados do ayllu em quechua. A tradição dos estudos de quechua foi iniciada em 1560 pelo frade andaluz Domingo de Santo Tomás (1951), que publicou, em Valladolid, a Lexicon o vocabulário de la lengua general del Peru. Foi ele o responsável pela primeira lista de palavras quechua com seus equivalentes espanhóis para utilização nos primeiros momentos da conquista. Ele batizou Runa Simi ou língua imperial do Tahuantinsuyu com o nome de quíchua, que se conservou mesmo com algumas diferenças fonéticas ou ortográficas.

O entusiasmo desse doutrinador de Chicama e de Chincha pela aprendizagem do quechua se deve à grande tarefa de captação da alma indígena para mesclá-la com o espírito cristão e ocidental (Barrenechea, 1989).

A época de Toledo é favorável ao desenvolvimento dos estudos de quechua para proporcionar maiores conhecimentos sobre os grupos nativos. A história, os mitos e a organização do povo inca transparecem nos vocábulos simbólicos. No final do século XVI, continua-se ampliando a análise da língua e sua estrutura, assim como há um aumento do número de vocábulos conhecidos que foram apresentados por González Holguin (1989) e Torres Rubio (s. d.). Essa é a época dos sermões de Ávila (1987), dos estudos filológicos de La Vega (1991), em seus Comentarios reales, e das crônicas bilíngues de Guaman Poma de Ayala (1993) e Santa Cruz Pachacuti (1993). 
González Holguin publicou em 1607 sua Gramatica e em 1608 seu Vocabulario, sendo este último de grande valor para os estudos de quechua por causa da grande quantidade de vocábulos e por suas inovações fonéticas. Sua intenção era usar os idiomas indígenas como instrumentos de cristianização (Barrenechea, 1989, p.XIII; Sáenz, 1985, p.22).

Torres Rubio teve grande prestígio no século XVII, pois dominou o quechua, o aymara e o guarani. De todos eles, publicou Vocabularios, como a Arte de la lengua aymara, em 1616; Arte de la lengua quíchua, em 1619; e a Arte de la lengua guarani, em 1627. Durante trinta anos se dedicou ao ensino da língua aymara em Chuquisaca e Potosi, demonstrando grande habilidade didática. Por causa de seu conhecimento linguístico, adquiriu grande fortuna, pois suas obras eram sucintas e de fácil consulta (Barrenechea, 1989, p.XIII-XIV).

Ávila foi um dos melhores escritores da língua quechua. Nascido em Cuzco em 1573, educou-se no colégio jesuítico da cidade e entrou para a carreira eclesiástica em 1596. Como cura de San Damián de Huarochiri, lutou contra os ritos gentílicos sobreviventes, acabando com ídolos, conopas (objetos sagrados caseiros) e amuletos. Predicou contra os deuses mais venerados da região, entre eles, as montanhas Pariacaca e Chaupiñamoc, e ao mesmo foi coletando as lendas andinas na própria língua original. Tendo sido acusado de cometer abusos contra os índios, conseguiu defender-se e pediu para ser transferido para outra paróquia. Em 1610, foi nomeado pelo arcebispo de Lima, Lobo Guerrero, primeiro visitador de idolatrias. Nessa função, deu prosseguimento às suas pesquisas sobre a sobrevivência da antiga fé nos povoados de San Damián, Mama, San Pedro de Casta, Huarochiri e San Lorenzo de Quinti. Profundo conhecedor de quechua, predicava todos os dias aos indígenas em seu próprio idioma (Barrenechea, 1989; Sáenz, 1985).

A obra Vocabulario de la lengua general del Peru llamada Quichua, y en la lengua española publicada em 1586 tem por autor Antonio Ricardo, mas ele próprio indica que não o é. Essa obra foi atribuía a vários autores, como: González Holguin, Santo Tomás, Torres 
Rubio, Blas Valera e Juan Martinez. Quase todos os quechuístas da época foram apontados como presumíveis autores, mas ainda não se chegou a nenhuma conclusão plausível (Risco, 1951). Essa obra foi preparada a pedido do III Concílio Provincial de Lima (1583) com o propósito de facilitar a catequização dos indígenas (ibidem).

Como pudemos perceber, a produção desses léxicos tinha como objetivo principal facilitar o processo de evangelização dos povos indígenas. Para nosso estudo, eles são primordiais em conjunto com as crônicas, pois não apenas conseguimos ter acesso ao significado do ayllu em quechua, como também pudemos compará-lo com as diversas interpretações fornecidas pelos cronistas a respeito dessa estrutura, ainda mais quando estes são profundos conhecedores da língua nativa, como é o caso de Francisco de Ávila.

Quando alguns cronistas escreveram sobre o ayllu, equipararam-no à parcialidad, ou seja, ao suyu, que possui conotação territorial como veremos a seguir.

No dicionário de Diego González Holguin (1989, p.39) aparecem as seguintes definições:

Ayllu. Parcialidad genealogía linaje, o parentesco, o casta.

Suyu. Parcialidad.

Hanan suyu. El de arriba.

Hurin suyu. El de abaxo.

O próprio nome do império inca carrega a noção territorial de suyu: "Tahuantin suyu. Todas quatro prouincias del Perú" (ibidem, p.333).

Já Domingo de Santo Tomás (1951, p.74, 136, 232) apresenta o seguinte:

Família-ayllo

Parentesco, sangre - ayllo

Ayllo, o villca - linage, generaciõ, o família

Suyu-parte assi divisa. 
Essas observações mostram como era usual entre os espanhóis conceber um mundo bipartido ou quadripartido geograficamente, mas que era difícil entender uma divisão de acordo com o sistema de parentesco e não pela espacialidade. A palavra parcialidad correspondia a uma metade sociopolítica de um senhorio, que, por sua vez, compreendia vários ayllus. Interpretações dúbias desse vocábulo devemos a González Holguin e Sarmiento de Gamboa, que conceberam ayllu e parcialidad como sinônimos (Canseco, 1981, p.38). Referindo-se aos ayllus de Cuzco, Sarmiento Gamboa, (1988, p.52) afirma: "a lo cual por el interés se movieron diez parcialidades o ayllus que quiere decir entre estos bárbaros linaje o Bando".

A posse de terras não era um requisito para o ayllu, pois havia os ayllus que migravam de um lugar para outro e também os de pescadores e de artesãos. Apesar da dificuldade de entendimento dessa estrutura, Francisco de Ávila (1966, p.257) nos apresenta uma visão de ayllu diferente da dos seus conterrâneos:

[...] ayllo quiere decir un número de gente que tuvo origen como si dixessemos Mendoças, Toledos. Y éste comúnmente es un peñasco o una cumbre de un monte, tiene su especial sacerdote y bien suele tener sementera y se hazen fiesta cada año.

Ao analisarmos algumas obras da época, percebemos que o ayllu era uma unidade de parentesco que tinha mesma origem mítica e que o suyu (ou parcialidad), como já vimos, indicava as divisões sociopolíticas dos vários ayllus agrupados, elementos que vieram a facilitar a organização incaica. Isso significa que o suyu servia para nomear as metades e as grandes divisões geográficas do mundo andino, possuindo um sentido mais amplo do que a palavra castelhana parcialidad, pois está vinculado a grandes áreas territoriais, mas sempre conservando sua ideia principal de ser uma porção de um todo (Canseco, 1981, p.43).

Também encontramos dois dicionários da época em que aparecem definições de ayllu, que não representam o vínculo territorial, mas o vínculo de sangue: 
Ayllu-tribu, genealogia, casa, família

Aylluni, aylluchani-Dividir por sus tribus

Aylluni-Iuntar gente, o animales

Aylluchani-Hacerse de un tribu. (Ricardo, 1951, p.18)

Ayllu-linaje

Ayllu - es un linaje o parentela. (Rubio, s. d., p.42)

Isso é bastante significativo por causa da dificuldade de se analisar o mundo andino de acordo com as crônicas e alguns documentos quinhentistas, pois existe uma confluência de discursos que pode apontar as mais diversas representações do ayllu e suas transformações ao longo de todo o século XVI. Tais representações podem estar de acordo com interesses pessoais, preconceitos, ignorância ou grande conhecimento diante do novo, problemas linguísticos, enfim uma série de fatos que geram discursos contraditórios, confusos, elucidativos, e cabe ao pesquisador destrinchar esse quebra-cabeça.

Outro problema que encontramos ao pesquisar esse tema é o fato de os cronistas nem sempre terem feito menção à palavra ayllu, e sim às suas características ou ainda a outros vocábulos com esse mesmo significado. Por exemplo, no norte do Tahuantinsuyu, as unidades sociopolíticas se articulavam por meio das pachacas e huarangas como princípios organizativos dos grupos étnicos. No caso de Cajamarca, os documentos do século XVI não mencionam o termo ayllu quando se referem a unidades sociais, mas fazem alusão à palavra pachaca. Não sabemos se ayllu e pachaca podem ser considerados sinônimos, embora Canseco (1981, p.39) e Soriano (1981, p.114) acreditem que sim, no que concerne ao norte da serra andina (Canseco \& Remy, 1992, p.72-3).

Estamos diante do fato de que os cronistas se apropriaram de um signo andino e na maioria das vezes o reinterpretaram, o que, na prática, pode significar que, ao lermos as crônicas, estaremos lidando com discursos diversos adaptados ou não às necessidades do sistema colonial. 
Além das crônicas, temos ainda outros documentos para trabalhar a representação do ayllu como as visitas, que são entrevistas e informes escritos durante o século XVI com base em questionários elaborados em Lima pelos funcionários da Real Audiência ou por outras autoridades interessadas em saber a realidade econômica e social de uma região. $\mathrm{O}$ objetivo era saber o que as províncias produziam, o número de habitantes e, mais que tudo, o de tributários, além da quantidade de povoados, ayllus, pachacas, huarangas, sayas e parcialidades. Também a qualidade e quantidade do tributo que os incas lhes impuseram e o que davam a seu encomendero espanhol. Os eclesiásticos também realizaram suas visitas, mas com o interesse de conhecer os mitos e as tradições dos povos para dar subsídios à campanha de Extirpação de Idolatrias, que não será abordada neste trabalho.

Espinoza Soriano publicou a visita a Cajamarca de 1540, em que, em momento algum, há uma preocupação em se perguntar pelos ayllus, muito embora se pergunte pelos seus curacas. Esse é um exemplo da possível confusão entre os termos ayllu e parcialidad.

Tenéis cuidado, e ansí a vos lo mandamos, que sepáis las parcialidades que hay en la tierra de cada cacique, e cual es el que más manda. E si las hubiere las asentaréis por sí a cada parcialidad con sus indios aparte con el cacique que las mandare. (Barrientos, 1967, p.23)

Não mencionar os ayllus é compreensível porque, no começo da colonização, o importante era listar territórios e seus chefes para que fossem posteriormente repartidos entre os conquistadores, além das dificuldades linguísticas já mencionadas. Na visita de Francisco de Toledo (1924, p.133), começam a aparecer questionamentos a respeito dos ayllus:

Os informaréis cuantas parcialidades hay en cada repartimiento y qué caciques y principales son los que al presente mandan y tienen las dichas parcialidades, y comenzaréis la visita asentando distinta, y apartadamente los indios de cada parcialidad [...] comenzando por el cacique principal 
estando el dicho cacique y su mujer y todos sus hijos, legítimos y bastardos, con sus nombres e edades; $y$ después de todos ellos todos los indios de su parcialidad y ayllu, por la dicha orden [...]

Como vimos, não é possível seguir, por exemplo, o método de Ake Wedin (1966), ou seja, dar preferência às crônicas tardias, já que estas seriam as mais verossímeis por serem resultado de uma vivência e da memória oral. No nosso caso, teríamos sérios problemas, pois os cronistas que primeiro chegaram ao Peru descreveram o momento da conquista e não mencionaram o ayllu. ${ }^{2}$ Mesmo assim, deixaram transparecer em seus escritos algumas características relativas ao modo de organização dos povos do antigo Peru, o que valida o seu interesse. Relacionando esses dados com os de cronistas posteriores, encontramos as representações dadas a essa estrutura nos diferentes momentos históricos que nos interessam.

Não podemos deixar de mencionar também o fato de que o plágio foi uma prática nos séculos XVI e XVII e que os cronistas costumavam usar fontes de informação comuns. Interessa-nos então saber em que lugar e época o cronista coletou seus dados e a que público estava dirigindo sua obra. Por exemplo, há quatro grandes cronistas que escreveram suas obras baseados na memória oral dos nobres cuzquenhos e, por isso mesmo, coincidiram no tocante aos mitos de criação dos incas, embora haja diferença em relação aos acontecimentos históricos incaicos. Foram eles: Cieza de León, que coletou dados para escrever El señorio de los incas por volta de 1550; Juan de Betanzos, que acabou de redigir sua crônica em 1551; Sarmiento de Gamboa, que terminou sua obra em 1572; e Cristóbal de Molina, que acabou a redação da sua em 1575. Apesar disso, é necessário muito cuidado ao utilizar as crônicas, pois não se pode confundi-las com fontes escritas que tratem da história dos incas como se fosse uma biografia. Por exemplo, quase todos os cronistas

2 Por exemplo, as crônicas de Francisco de Xerez, Diego de Trujillo, Cristóbal de Mena, Miguel de Estete, Pero Sancho de Hoz, Pedro Pizarro, entre outros. 
trataram das "dinastias" incaicas de acordo com o modelo europeu, o que gera uma série de discrepâncias entre eles sobre quem conquistou mais territórios ou sobre a história de Atahualpa e Huascar. Esse translado de modelos europeus para os Andes faz que apareçam duas grandes concepções políticas defendidas por diversos cronistas. De um lado, o posicionamento encabeçado por Garcilaso de la Vega, que apresenta o Estado inca como uma utopia, onde as pessoas não passavam nenhuma necessidade e todos os grupos étnicos tinham se deixado subjugar por causa dessa bondade incaica, e, de outro, Sarmiento de Gamboa, que considera os incas tiranos e usurpadores, mostrando que eles só conseguiram o poder porque utilizaram muita violência, dessa forma, ele legitimou a conquista espanhola, pois eles teriam vindo salvar as populações andinas (Pease, 1978, p.33-5). No caso de nossa pesquisa, também podemos perceber a influência de modelos europeus quando os cronistas se referem ao ayllu com conotação da comunidade camponesa medieval, que tinha o vínculo territorial como ponto de coesão.

Os cronistas deixaram testemunhos mesclados a familiaridades conceituais, o que nos faz perceber mais uma vez que estamos lidando com representações da história do mundo andino. Por isso, quando os espanhóis descreveram o domínio territorial andino, equipararam-no ao modelo europeu de grande quantidade de terra dividida em províncias e controlada por administradores que estavam concentrados em Cuzco. Porém, de acordo com a visita de Huanuco (Zúñiga, 1967, 1872), por exemplo, percebemos que o importante não era o controle territorial, mas sim os recursos humanos disponíveis para o trabalho e a burocracia responsável por esse controle que partia do curaca local. Mais uma vez, estamos diante da importância do ayllu como núcleo básico da organização social, econômica e política andina. O vínculo de parentesco estava acima do vínculo territorial, até porque o primordial era o controle da mão de obra disponível tanto em tempos pré-incaicos entre os pequenos grupos locais como depois da implantação do Tahuantinsuyu.

Passaremos a examinar as representações que os cronistas deram a essa estrutura tão importante para o entendimento da histó- 
ria peruana. Antes, porém, gostaríamos de lembrar ao leitor que, no final deste livro, encontram-se a biografia de todos os cronistas aqui relacionados e a cronologia do século XVI, que em conjunto podem proporcionar um melhor entendimento das questões que apresentaremos no próximo item. Em razão do grande número de edições de cada crônica, optamos por utilizar as publicações mais recentes que, em geral, passaram por revisões detalhadas. No caso da crônica de Polo de Ondegardo, usamos duas edições, pois a do início do século é mais completa e a versão contemporânea, apesar de resumida, apresenta várias notas elucidativas a respeito do conteúdo dessa obra. Lembramos ainda que não nos deteremos em detalhes sobre a vida dos cronistas, pois aquilo que ajuda a entender sua produção textual foi salientado em outros tópicos de nossa pesquisa e pode ser completado com as biografias, conforme já mencionado. Nosso interesse nos próximos tópicos é demonstrar como o ayllu foi representado pelos cronistas e de que modo a confluência desses discursos reflete as transformações ocorridas com essa estrutura ao longo do século XVI.

\section{A representação do ayllu pré-hispânico}

Ao estudarmos a representação do ayllu nas crônicas, percebemos que ele possui uma origem mística, conforme foi relatado por Cristóbal de Molina (1959, p.11-2). Depois do dilúvio, o Criador fez do barro os seres humanos e lhes disse que idioma falar e quais cânticos entoar. Em seguida, mandou que descessem à Terra e se espalhassem. Uns saíram de cavernas, outros de montanhas, fontes, árvores num processo de multiplicação que os transformou em huacas, os deuses de seus futuros descendentes. Os filhos das huacas passaram a se vincular por consanguinidade, formando o ayllu, instituição social-chave para interpretar e compreender o universo humano do Peru pré-colombiano.

Cada ayllu, para possuir uma existência independente, necessitava da origem comum e simbólica. A pacarina (local geográfico em 
que surgiram as huacas) e a huaca gentílica foram os elementos de integração interna do ayllu, do que se derivaram gerações sucessivas em um ordenamento sistemático e cronológico (La Vega, 1991). Os ayllus para se diferenciarem uns dos outros tinham por hábito que sua gente usasse roupas e penteados distintos.

$Y$ así dicen, que los unos salieron de cuevas, los otros de cerros, y otros de fuentes, y otros de lagunas y otros de pies de árboles, y otros desatinos desta manera; y que por haber salido y empezado a multiplicar destos lugares, en memoria del primero linaje que de allí procedió, y así cada nación se viste y trae el traje con que a su huaca vestían. (Molina, 1959, p.12)

A unidade do ayllu estava visível não só na origem comum, mas também no nome escolhido em ritual específico (Cieza de León, 1991, p.189-91), na sede de vingança (Cobo, 1956) contra quem atentasse contra um ou mais membros do ayllu e nas suas festividades fúnebres. Mencionamos festividades porque se realizavam cerimônias em que se consumia muita chicha (bebida fermentada do milho), muita comida e isso durante dias. O cemitério também era comum e exclusivo para cada ayllu, por isso, durante o período colonial espanhol, os índios retiraram os cadáveres de seus entes dos cemitérios cristãos e os levaram de volta ao cemitério de seus antepassados (Cieza de León, 1991, p.181-4).

Garcilaso de la Vega (1991, v.I, p.33-5) denomina de barbárie o período pré-incaico, em que, segundo ele, os povos viviam em cavernas, sem chefia, e roubavam, assassinavam e eram canibais. ${ }^{4}$ Sarmiento de Gamboa (1988, p.47-50) completa dizendo que só escolhiam um chefe em tempo de guerra, mas que, assim que esta terminava, voltavam a viver em behetrías ou em desordem. ${ }^{5}$ Essa é

3 Versão semelhante encontramos em Betanzos (1968, p.9).

4 Também descrevem o período de barbárie os cronistas Múrua (1986, p.95) e Cieza de León (1991, p.6).

5 A behetría a que nossos cronistas se referem foi analisada no segundo capítulo deste livro. Podemos citar ainda como exemplos Ondegardo (1990, p.51), 
a visão propagada pelos quipucamayocs, ou seja, os representantes da tradição oral inca, a quem convinha depreciar o passado em favor de uma legitimação de seu poder ante os grupos étnicos por eles conquistados.

Os incas aproveitaram a estrutura do ayllu para estabelecer suas bases político-econômicas. Ao conquistarem um grupo étnico, eles impuseram sua forma de ver o mundo, usando para tal a linguagem do parentesco. A ancestralidade em comum servia para camuflar as novas relações de poder, em que os incas passavam a usufruir da tributação solicitada a esses grupos consanguíneos. Para tal, eram estabelecidos laços de parentesco entre os curacas e o inca.

$Y$ ansí mismo les dio, a cada dos, vestidos de las ropas de su vestir, e a cada uno dellos les dio una señora, naturales del Cuzco, de su linaje, para que fuesen cada una destas mujeres principal del cacique a quien ansí le había dado, e que los hijos que en tales hubiesen, fuesen herederos de los tales estados e señoríos que sus padres tuviesen [...] (Betanzos, 1968, p.36)

Nem sempre o domínio incaico foi aceito, pois os cronistas relatam que foram inúmeros os casos de rebelião contra o incário (Mena, 1987; Xerez, 1985; Trujillo, 1985; Pizarro, 1978; Hoz, 1986), demonstrando assim a debilidade do império, que não foi eficaz na imposição de sua cosmovisão, fato esse bem aproveitado pelos espanhóis durante o processo da conquista.

Polo de Ondegardo (1990, p.46-50) conta que, durante o período incaico, diminuíram os confrontos entre os ayllus por terras, pois passaram a ter territórios de tamanho fixo e só as áreas destinadas à produção do Inca, do Sol e do curaca do ayllu podiam mudar de tamanho. Quando eram conquistados novos territórios, tudo era dividido entre o Inca e o Sol, e o restante era deixado para a subsistência do grupo subjugado, em que o curaca ficava responsável por tais terras e

Pizarro (1978, p.45). Jesuita Anónimo (1968, p.175), Santillán (1968, p.104) e Cieza de León (1991, p.6), que também consideraram o período pré-incaico um tempo de desordem e de behetrías. 
por controlar a prestação de serviços como tributo ao Estado inca. A terra era comunitária, porém a cada ano o curaca a dividia entre os integrantes do ayllu de acordo com o tamanho de cada família.

Preguntado si los indios de esta provincia tiene cada uno tierras señaladas por suyas o si todas las tierras son de común y se reparten en cada año entre los indios por sus caciques o qué orden es lo que en esto se tiene dijo que los indios tienen sus tierras y chácaras señaladas y que él tiene cargo cada año de visitarlas para que ninguno se entre en la tierra del otro y que cuando acaece morir algún indio que no deja hijos y deja mujer da éste que declara parte de las tierras a su mujer e las demás reparte entre los indios del ayllo donde era el indio que falleció entre los que los han menester y si el dicho difunto no deja heredero se reparten todas las tierras entre su ayllo. (San Miguel, 1964, p.35)

Para cultivar a terra estatal e construir e reparar os trabalhos de irrigação e as estradas, era requerido o trabalho individual como um serviço público depois de estabelecida a conquista do ayllu. Cada homem tinha que trabalhar por mitas, por turnos, na agricultura e em outros serviços públicos (Santillán, 1968, p.114-6; La Vega, 1991, p.261-2; Jesuita Anónimo, 1968, p.178; Cieza de León, 1991, p.147-8). A estocagem de grãos, raízes, fibras e lãs para tecelagem era organizada e levada para os tambos (depósitos) públicos e eles eram redistribuídos para aqueles que precisassem.

Las hay también que son o almacenes repletos de mantas, lana, armas, metales, paños y de todas aquellas cosas que se dan o se manufacturan en estas partes. Hay casas donde se guardan las contribuciones que traen a los caciques sus tributarios. (Hoz, 1986, p.137) ${ }^{7}$

6 Ver também Cobo (1964, p.122), Ayala (1993, p.268), Ondegardo (1990, p.46-63), Acosta (1954, p.193), Betanzos (1968, p.34), Zúñiga (1967, p.31), entre outros.

7 Ver também Ondegardo (1990, p.95), Brizeño (1965, p.161), Xerez (1985, p.87) e Trujillo (1985, p.206), entre outros. 
Cuidar da lã e do algodão era tarefa para mulheres, crianças e idosos, que tinham o trabalho de fiar e costurar. O Estado inca não proveu nenhuma outra necessidade para esses sujeitos, mas, para sua própria conveniência política, incentivou os cultos e os festivais religiosos populares (Ayala, 1993, p.239-48). O Sol e a Lua, durante o tempo do império, foram os principais deuses do culto oficial, pois eram considerados os ancestrais sagrados do Inca, tendo de ser venerados por todos os ayllus: "Toda esta región fría tiene esta adoración al Sol y a su hijo, el señor de la tierra, que así le llaman Hijo del Sol" (Estete, 1987, p.315). ${ }^{8}$

Existiam outras práticas religiosas em relação a Viracocha, Kon e Pachacamac, que foram considerados os criadores do mundo, das plantas, dos animais e dos homens (Cieza de León, 1991, p.50; Betanzos, 1968, p.49; Jesuita Anónimo, 1968, p.154). Tais deuses foram tolerados pelo Inca.

A todos mandavan unos y otros que por Dios adorasen al Sol; sus demás religiones y costumbres no se las prohibían, pero mandávales que se gobernasen por las leyes y costumbres que usavan en el Cuzco [...] (Cieza de León, 1991, p.47)

O fato de os incas se dizerem filhos do Sol fez que seus ayllus tivessem uma organização distinta dos demais. Ao Inca só era permitido casar com sua irmã de sangue para garantir a legitimidade de sua descendência. Ele tinha direito a várias esposas, ao contrário dos homens comuns, porém só os filhos com a irmã poderiam disputar o seu lugar. Dizemos disputar, pois estes tinham que provar ser hábeis para assumir as responsabilidades de chefiar o Tahuantinsuyu. O Inca e sua parentela formavam a panaca, que é o mesmo que ayllu real em quechua. Cada chefe inca tinha suas terras que eram plantadas pelos yanaconas (servos) ou por hatunrunas (homens comuns)

8 Mais informações sobre esses cultos, ver Santillán (1968, p.104, 111), Arriaga (1968, p.201) e Pizarro (1978, p.19). 
em tempo de mita (tributo estatal) (Zúñiga, 1967, 1967, p.25). A produção proveniente dessas terras servia para o sustento de sua família extensa mesmo após a sua morte, pois esta fazia parte da nobreza cuzquenha conforme as palavras dos cronistas.

Estos señores tenían de costumbre de tomar a sus hermanas por mugeres, porque dezían que nadie las merecía si ellos no. Auía un linaxe destas hermanas que desçendia de su misma línea destos señores, y los hijos destas heran los que eredauan el rreyno, siempre el mayor. Pues fuera de estas hermanas tenían estos señores todas las hijas de los caciques del rreyno por mancebas, y estas seruían a sus hermanas principales, que serían en número de muchas más de quatro mill. Tenían asimismo todas las yndias que bien les paresçian, repartidas por estas sus hermanas, que heran muchas. (Pizarro, 1986, p.47) ${ }^{9}$

Nas crônicas, encontramos com riqueza de detalhes a história dos chefes incas, colocando-os dentro do modelo europeu de nobreza em que estes se sucediam dinasticamente e o filho primogênito era sempre o herdeiro do trono, ${ }^{10}$ como verificamos no capítulo anterior. Embora saibamos que isso não corresponde à realidade andina, trata-se de representações de um mundo desconhecido em que se fazia necessária a familiaridade de temas para melhor compreendê-lo. No caso dos cronistas indígenas, eles tiveram a preocupação de se fazer entender pelos espanhóis, pois, na maioria das vezes, estavam reivindicando direitos perdidos durante o período colonial. Não afastamos o fato de que todos eles foram educados por espanhóis e, no conjunto das práticas culturais, passaram pelo processo de aculturação já examinado anteriormente, o que não significa que desconhecessem o passado andino.

9 Muitos foram os cronistas que trataram desse assunto, como Gamboa (1988, p.63-4), LaVega (1991, p.217, 438, 646-8), Ayala (1993, p.142), Cieza de León (1986, p.19, 25), Acosta (1954, p.200), Hoz (1986) e Pachacuti Yamqui Salcamaygua (1993, p.197) e outros.

10 Por exemplo, os cronistas Sarmiento de Gamboa e Pachacuti Yamqui Salcamaygua. 
Os ayllus de homens comuns, ao contrário das panacas, eram compostos por uma família extensa em que a endogamia se dava em relação à macroetnia, mas a exogamia era a prática normal entre as pequenas famílias. Em algumas crônicas, essas informações aparecem bastante confusas, pois havia o hábito entre os membros dessas parentelas de se autodenominarem irmãos. Porém, alguns cronistas ressaltaram o fato de o Estado inca proibir os casamentos dentro do mesmo grupo familiar.

Iten mandamos que ninguno se casasen con hermana, ni con su madre, ni con su prima hermana, ni tía, ni sobrina, ni parienta, ni con su comadre, so pena que serán castigados, y le sacarán los dos ojos, y le harán cuartos, y le podrán en los cerros para memoria y castigo, porque solo el Inga ha de ser casado con su hermana carnal por la ley. (Ayala, 1993, p.142)

Havia ainda as diferenças entre os ayllus da serra e os da costa, o que foi muito comentado pelos cronistas, que, por vezes, mostraram certo desdém e até mesmo desprezo em relação aos povos costeiros.

Ninguno de los señores con mando en esta provincia ha tomado en cuenta a los habitantes de la costa por considerarlos tan ruines y pobres. Sólo se servían de ellos para obtener pescado y frutas [...] (Hoz, 1986, p.132) $)^{11}$

Os ayllus da serra, na maioria das vezes, eram grupos sedentários e, por isso, possuíam um assentamento territorial, onde tinham suas casas e terras próprias para o plantio. Embora a terra fosse coletiva, como cada família tinha seu próprio espaço destinado à produção de alimentos para sua subsistência, eles costumavam construir a casa nas proximidades dessa área, e, assim, as casas costumavam ser isoladas umas das outras, conforme as palavras de Pablo Jose de Arriaga (1968, p.200-21). Algumas vezes, formavam pequenas al-

11 Ver também Pizarro (1953, p.60-3), Titu Cusi Yupanqui (1992, p.34) e Xerez (1985, p.104). 
deias e até bairros quando moravam em grandes cidades por motivos determinados (Múrua, 1986, p.52-3; Hoz, 1986, p.137; Molina, 1968, p.73; Ayala, 1993, p.276-7), que, no tempo dos incas, costumavam estar relacionados às formas de pagar o tributo devido ao Estado. Os componentes dos ayllus serranos habitavam espaços definidos e conhecidos, onde todos tinham seus direitos comunais sobre as terras, as fontes de água, os pastos, enfim, tudo o que fosse necessário ao sustento. Os ayllus eram defendidos coletivamente contra a invasão de estranhos ao seu núcleo parental. Tudo era compartilhado e dividido pelo curaca local entre os integrantes do ayllu.

Asimismo tenían cuidado de rrepartir tierras a los naturales de su gouernaçión, señalando a cada indio lo que le uastaua, y asimismo el agua que auía de tomar para el benefiçio dellas, si era tierra daçequias, que en toda la mayor parte deste rreyno las auía y las usauan, aunque fuese en la sierra donde llueue. Usauan de acequias para el arar las tierras y sembrar, y después qyedauan a las lluvias. (Pizarro, 1978, p.96) 12 $^{12}$

Já na costa, segundo alguns cronistas, o ayllu era composto por uma família extensa, que não necessariamente possuía um território. Formava-se um clã, e sua unidade se dava pela ocupação de um espaço, que podia mudar de acordo com as necessidades do grupo, que na maioria das vezes se dedicava ao artesanato, à pesca e ao comércio (Relación Sámano, 1985, p.183). Segundo o cronista Pero Sancho de Hoz (1986, p.131-2), na costa a terra era muito arenosa, onde não crescia erva e quase não chovia. Porém, o milho e as frutas se davam bem porque eram regados com água proveniente das montanhas. As casas dos camponeses eram feitas de junco, e, como não chovia e fazia muito calor, poucas tinham teto. Por ser região de muita areia, havia muita gente cega. Escasseavam o ouro e a prata, e o pouco que tinham era oriundo de trocas com gente da serra. A área junto ao mar, segundo Hoz, era toda muito semelhante e os homens

12 Ver também Ondegardo (1990, p.68) e Ayala (1993, p.142). 
que aí viviam vestiam roupas simples de algodão, comiam milho cozido ou cru e carne malpassada.

Os ayllus serranos, por serem grupos que tinham por base o sistema de parentesco e a posse coletiva de um determinado território, enfrentavam problemas fronteiriços com seus vizinhos, pois seus limites eram demarcados por barreiras naturais ou artificiais, o que gerou grandes litígios, por vezes, sangrentos, como podemos comprovar examinando documentação da época. Polo de Ondegardo (1916), que na segunda metade do século XVI defendia a não perpetuação da encomienda e os índios contra a exploração espanhola, afirma que não existiram tais conflitos por terras, já que esta era coletiva em tempos incaicos. Tal pensamento está de acordo com a defesa de seus interesses, mas os pleitos existentes nos arquivos espanhóis e peruanos o desmentem.

Nas crônicas, encontramos vários relatos sobre as terras agrícolas do ayllu que eram divididas em lotes denominados tupus.

Era bastante um tupu de tierra para el sustento de um plebeyo casado y sin hijos. Luego que los tenía le daban para cada hijo varón otro tupu e para las hijas a medio. Cuando el hijo varón se casaba de daba el padre la fanega de tierra que para su alimento había recibido, porque echándolo de su casa no podía quedarse con ella.

Las hijas no sacaban sus partes cuando se casaban, porque no se las habian dado por dote sino por alimentos. Que habiendo de dar tierras a sus maridos no las podían ellas llevar, porque no hacían cuenta de las mujeres después de casadas sino mientras no tenían quién las sustentase: como era antes de casadas y, después, de viudas. Los padres se quedaban con las tierras, si las habian menester. Y si no, las volvían al concejo porque nadie las podía vender ni comprar. (La Vega, 1991, p.258)

Essa informação de La Vega nos mostra que a mulher não tinha os mesmos diretos do homem, muito embora, na hora de pagar tributo ao Estado, fosse tão penalizada quanto.

Nesses pequenos tupus, também estavam os pastos, as fontes e as terras destinadas à produção para a huaca. As terras que sobravam por não serem necessárias à manutenção do ayllu foram tomadas pelo 
Estado inca, que as destinou à produção estatal e do Sol (Gamboa, 1988, p.134-5). Podemos verificar que, nos séculos XV e XVI, havia três tipos de direito à terra: coletivo, estatal e familiar, este, de certo modo, privado.

Constatamos, então, que os territórios pertencentes aos ayllus eram bem conhecidos por seus integrantes, que podiam circular livremente neles, não impedindo que outras pessoas neles circulassem, desde que não permanecessem, caso contrário, seriam expulsas.

Os ayllus andinos, para melhor controlar os diversos microclimas e ter acesso a todo tipo de alimento, deslocavam algumas de suas famílias a lugares distantes para que pudessem cuidar de plantações diversas. Por isso, os espanhóis que fizeram as primeiras visitas na região norte dos Andes foram unânimes em descrever o quanto eram pequenas as aldeias dos ayllus ali encontradas, mais conhecidas por llactas (Holguin, 1989, p.207). Muitas possuíam apenas dez pessoas em duas ou três casas, e em uma dessas aldeias vivia o curaca, constituindo, assim, a principal aldeia do suyu (território) desse ayllu (La Bandera, 1965, p.96-104).

Preguntado si los indios que están em la coca son naturales de la tierra o mitimaes puesto de otra parte y de dónde son naturales dijo que los tres indios que están en la coca de Pichomachay son el uno del pueblo Pecta otro de Atcor y otro de Guacas [...] (Zúñiga, 1967, p.43-4)

As atividades produtivas dentro do ayllu eram compartilhadas por todos, incluindo mulheres, anciãos e crianças. Os instrumentos e as técnicas eram rudimentares, e o trabalho se organizava partindo de uma cooperação mútua (ayni), em que a colaboração e a reciprocidade ocorriam entre todos os membros do ayllu. Não existia diferença entre ricos e pobres, dominadores e dominados, apesar da presença do curaca, pois este nada decidia sem consultar outros integrantes do ayllu, sempre atendendo aos interesses da coletividade (Falcon, 1867, p.470; La Vega, 1991, p.255-85; Ayala, 1993, p.183-5; Molina, 1968, p.75; Cieza de León, 1991, p.54-5), fato que muito mudou no período colonial, conforme verificaremos. Ele era 
o responsável, junto com um conselho de chefes de família ou homens idosos, por solucionar todos os problemas locais, civis, políticos e administrativos, assim como a divisão da água e das terras e os crimes dentro do grupo. Ele governava de acordo com os costumes, e o conselho reforçava seus decretos. Porém, os crimes contra a religião, o Estado e o Inca eram considerados problemas concernentes ao Estado, sendo julgados diretamente pelos representantes do imperador, podendo receber a pena de morte: "De suerte que los vícios eran bien castigados y la gente estaba bien sujeta y obediente. $Y$ aunque en las dichas penas había exceso, redundaba en buen gobierno y policía [...]" (Santillán, 1968, p.107). ${ }^{13}$

Nas crônicas, também encontramos referências aos ayllus de mitmaq, que não estavam concentrados em um só lugar, mas espalhados em um ou mais ayllus em diferentes regiões do Tahuantinsuyu. Isso significa que seus territórios estavam em diferentes pisos ecológicos e que suas casas podiam ser construídas em terras de outros ayllus.

Los reyes incas transplantaban indios de unas provincias a otras, para que habitasen en ellas. Hacianlo por causas que les movian - unas en provecho de sus vasallos, otras en beneficio propio -, para asegurar sus reinos de levantamientos e rebeliones. (La Vega, 1991, p.415)

Esse tipo de organização, como já vimos, não era desconhecido para os espanhóis, pois, na Europa durante a Idade Média, foi comum a divisão entre os camponeses de pedaços de terra em diferentes regiões agrícolas com o objetivo de compartilhar entre todos as terras boas e más para que houvesse igualdade na produtividade.

13 Ver também Ondegardo (1916, p.13, 65), Jesuita Anónimo (1968, p.178)e Cieza de León (1991, p.77).

14 Ver também Gamboa (1988, p.111), Ondegardo (1916, p.79) e Ayala (1993, p.148), Cieza de León (1991, p.63), Matienzo (1967, p.9), Santillán (1968, p.114), Cangas \& Otazu (1991, p.139,140) e "Instrucción que el Marqués Francisco Pizarro dio a Diego Verdejo...” (1921, p.22-3). 
Nos Andes não foi diferente, agregando-se o fato de que os ayllus queriam ter acesso a produtos de diferentes regiões para satisfazer todas as necessidades de subsistência, bem como obter produtos para o intercâmbio, mas nunca com fins acumulativos. Além disso, a necessidade de descansar os campos agrícolas também era responsável por essa descontinuidade territorial.

Na serra encontramos ainda os ayllus que não tiveram território nenhum, pois eram compostos por yanaconas, ou seja, servos que em troca de seu trabalho tinham a permissão do Inca para habitar suas terras e que, embora pudessem pertencer a um só ayllu, podiam estar divididos em duas ou três regiões distintas e até mesmo bem distantes entre si.

Asimismo tomaba el inga y aplicaba para sí, de cada valle o provincia yanaconas, el número que le parescía, y estos escogía de la mejor gente y los más hijos de curacas, y gente recia y de buena disposición, a los cuales, como criados suyus, les hacía esemptos de los curacas, que no tenían en cuenta con ellos, salvo el gobernador del inga, que les ocupaba en cosas de su servicio, y algunos llevaba al Cuzco y los tenía en su servicio, y a éstos hacía algunas veces curacas en sus provincias. Otros ponía en las casas de los señores muertos, porque como siempre había de estar el servicio en pié, en faltando algunos yanaconas y servicio, suplíalo el inga de los que él tomaba y hacía en cada provincia. (Santillán, 1968, p.114) (15 $^{15}$

A documentação do século XVI também mostra que as pacarinas ou locais de origem, na maioria das vezes, ficavam em regiões distantes dos seus ayllus e, por vezes, eram adoradas por diversos ayllus que formavam uma macroetnia.

[...] que cada ayllo y parcialidad de los indios tiene su principio, y Pacarina, que ellos llaman particular y nombran y la adoran y ofrecen sacrificio, llamándola Camac, que es Criador, y cada uno dice que tiene su

15 Ver também Betanzos (1968, p.54), Cieza de León (1986, p.52) e “R. Provision dando licencia a los pobladores del Peru..." (1953, p.142). 
Criador, unos dicen que tal cerro, otros que tal fuente, otros cuentan de sus Pacarines muchas fábulas y patrañas. (Arriaga, 1968, p.220)

Os ayllus conservavam junto a si as múmias de seus antepassados, que igualmente eram adorados, assim como suas huacas. As múmias eram chamadas de malquis e possuíam até chácaras (Cangas \& Otazu, 1991, p.49), que eram semeadas por seus familiares, pois, como forma de reverenciá-las, levam-lhes comida, bebida e outras oferendas diariamente. Em época de festas, as múmias eram levadas para o povoado em meio a muita música e dança, e as pessoas ficavam dia e noite espantando as moscas, conforme o relata Pero Sancho de Hoz (1986, p.142). ${ }^{16}$ As huacas, segundo Pierre Salomon (1991, p.16-7), eram os objetos sagrados que simbolizavam a origem do grupo clânico e podiam ser montanhas, cavernas, múmias e até antigas ruínas. As huacas representaram importantes corporações sociais e políticas, pois o chefe do ayllu era sempre o descendente da huaca, e, por isso, cada ayllu tinha a sua huaca particular, diferentemente da pacarina, que podia ser compartilhada por vários ayllus. Segundo o manuscrito de Huarochiri, as huacas serviam para resolver todos os problemas do grupo e, por isso, tinham seus próprios sacerdotes e sacerdotisas (Ávila, 1987, p.229) que serviam de intermediários e cuidavam delas.

[...] porque cada parcialidad o ayllo tiene su huaca principal, y otras menos principales algunas veces, y de ellas suelen tomar el nombre muchos de aquel ayllo. Algunas de estas las tienen como a guardas y abogados de sus pueblos, que sobre el nombre propio llaman Marca aparca o Marcacharac.

Estas huacas tienen todas sus particulares sacerdotes, que ofrecen los sacrificios, y aunque saben todos hacia dónde están, pocos las ven, porque ellos se suelen quedar atrás y sólo el sacerdote es que le habla y ofrenda. (Arriaga, 1968, p.202)

16 Outros relatos interessantes sobre os malquis podem se encontrados em Pizarro (1986, p.52), Matienzo (1967, p.128-9) e outros. 
Os ayllus aliados que ocupavam territórios vizinhos constituíam organizações mais amplas, que são chamadas de huarangas no norte e de sayas no sul. Por isso, quando os espanhóis deram o nome de parcialidades aos ayllus, às huarangas e às sayas, que é o mesmo que metades, não ficaram muito distantes de compreender a organização dessas unidades étnicas, pois tal palavra no século XVI significava porção de uma parte maior. Quando os ayllus eram independentes uns dos outros, os espanhóis os chamaram de behetrías, pois, como já vimos, na Alta Idade Média hispânica, o vocábulo behetría foi usado para indicar a liberdade que alguns habitantes de povoados tinham de trocar de senhor feudal quando quisessem. Esse sistema tornou-se tão confuso que posteriormente esse termo foi utilizado como sinônimo de desordem, anarquia, desgoverno etc. Esse é o sentido utilizado pelos cronistas do século XVI quando se referem aos ayllus sem chefes, ditos por eles behetrías andinas (Fernández de Oviedo, 1959, p.427).

As fontes referentes à região norte dos Andes mencionam a existência de pachacas ao invés de ayllus, e, de acordo com os dicionários da época, pachac (Santo Tomás, 1951, p.333; Holguin, 1989, p.270), entre outros significados, era um grupo de cem famílias nucleares, o que era bastante apropriado, visto que assim o Estado inca podia dispor de cem homens capazes de trabalhar quando o Estado necessitasse: "[...] y para tener más particular noticia de todos hizo otra división y dio cargo de cada cient indios a un curaca, al cual llamaban señor de pachaca [...]”' (Santillán, 1968, p.105).

Embora esse sistema fosse pré-incaico, os incas souberam reaproveitá-lo a seu favor, e, durante o império, esses serviços obrigatórios de cada ayllu foram regulados pelo governo do Estado. Famílias e cidades foram registradas e divididas por regiões em grupos de dez, cem e mil, e para cada unidade um chefe era nomeado para controlar esses serviços. Os cronistas divergem um pouco quanto a essa divisão, pois uns chegam à divisão de dez mil ayllus, e outros a fazem de cinquenta em cinquenta, mas todos dizem ser um sistema decimal que tem como chefe principal o Inca (Gamboa, 1988, p.132; Ondegardo, 1916, p.56, 1990, p.45; Cieza de León, 1991, p.69). 
[...] y entre cada diez curacas destos escogía el más hábil para mandar y más hombre, y hacíale curaca sobre los otros nueve, y éste tenía cargo de los nueve curacas y de su gente, y los mandaba, y ellos le obedecían y estaban subjetos; a éste llamaban curaca de guaranga, que dice señor de mill indios. Y cada un señor de pachaca ponía un mandón que le ayudase cuando él estuviese ausente, y para el gobierno de todo un valle donde había muchos guarangas, ponía un señor sobre todos que llamaban Huño el cual era gobernador sobre los curacas de pachaca y guaranga, y ellos le obedecían como señor. Y para las cosas tocantes al tributo del inga, y para ser si sus mandatos y régimen que él ponía se guardaban, era sobre todos el Tocricoc [...] (Santillán, 1968, p.105-6)

A mita ${ }^{17}$ era rigorosamente imposta para todos os serviços estatais, para os quais era necessário um enorme contingente de homens à disposição. Esse trabalho estatal consistia em construir aquedutos, estradas, pontes, templos, palácios e fortalezas, cuidar dos rebanhos, trabalhar nos campos, participar das conquistas, de acordo com a política imperialista do Inca. Como os homens devotavam todo o seu tempo a esses serviços, o Inca os provia com hospedagem e comida.

$\mathrm{Na}$ visita de Huanuco, encontramos dados interessantes sobre a mita solicitada pelo Inca, que foram coletados por Juan de Mori e Hernando Alonso Malpartida (1967, p.289-310) em 1549 junto aos índios chupachos. Todos os anos eram solicitados três casais para irem trabalhar nas minas de ouro e sessenta nas de prata. Fora isso, eram solicitados quatrocentos índios para construir paredes em Cuzco, outros quatrocentos para plantar nas chácaras de Cuzco, cento e cinquenta para servir de yanaconas a Guaynacava (Huayna Capac), cento e cinquenta para vigiar a múmia de Topa Ynga Yupanqui, mais quatrocentos e trinta para servir de guardas em diversas funções e locais, cento e vinte para trabalhar com plumas, outros sessenta para coletar mel, duzentos e quarenta para vigiar gado, quarenta para plantar pimenta, sessenta para colher coca, quarenta car-

17 "Mitta mitta. A menudo a cada paso cada credo, o momento, o en todas las ocasiones” (Holguin, 1989, p.243). 
pinteiros, quarenta ceramistas, oitenta carregadores e uma série de outras coisas que tinham que ser feitas por turnos, que não necessariamente eram fixos e obrigatórios como acabou ocorrendo com as mitas coloniais, que tantas rebeliões indígenas geraram. O resultado de todo esse trabalho era revertido em favor da comunidade, que cumpria sua tributação junto ao Estado e, caso necessitasse, por meio do sistema de redistribuição era contemplada com tudo o que fosse necessário à sua subsistência.

Depois deste estudo sobre as representações do ayllu pré-hispânico nas crônicas, percebemos que podemos encontrar cronistas que o interpretaram como uma estrutura baseada em laços de consanguinidade ou como espaço territorial habitado por um certo número de pessoas, mais propriamente, um povoado, ou ainda como uma representação mesclada em que o ayllu aparece com características territoriais e parentais. Esse é o resultado das práticas culturais entre espanhóis e indígenas que podem ser vislumbradas nas fronteiras discursivas presentes em suas crônicas.

\section{O ayllu colonial nas crônicas}

Quando os espanhóis chegaram ao Novo Mundo, fizeram o repartimiento, ou seja, a apropriação e distribuição de terras e índios entre os conquistadores. Os espanhóis não tinham a intenção de cuidar da terra, logo precisavam dos conhecimentos e da mão de obra indígenas, e, assim, as propriedades rurais pertencentes ao Sol e ao Inca foram as primeiras a ser repartidas. Os espanhóis também dividiram as terras dos ayllus, condenando o sistema inca de coletividade da terra e abrindo caminho para todos os abusos associados ao sistema de encomiendas ${ }^{18}$ e reduções. ${ }^{19}$

18 "La encomienda es una institución de origen castellano, que pronto adquirió en las Indias caracteres peculiares que la hicieron diferenciarse plenamente de su precedente peninsular. Por la encomienda, un grupo de familias de indios, mayor o menor según los casos, con sus propios caciques, quedaba sometido a la autoridad 
Francisco de Xerez (1985, p.81) conta que, quando Pizarro chegou, a primeira coisa que fez foi repartir as terras entre seus homens, visto que estes sem a ajuda dos índios não teriam como se sustentar nem povoar essas terras. Fora isso, segundo ele, os caciques precisariam estar sob o comando dos espanhóis, caso contrário poderiam sofrer grandes danos. Já com o conhecimento de quais índios administrar, os espanhóis os tratariam muito bem e os protegeriam. A ideia inicial foi uma, mas com o tempo acabou se convertendo em prejuízo para os índios, conforme o descreve Cristóbal de Molina (1968, p.64):

[...] les hizo repartimientos y los señaló a los españoles, dando por provincias de esta manera unas lejos e otras cerca, diciendo que las de cerca eran para el servicio personal de la casa de cada español [...] y de aquí quedó esta pestilencia de servicio personal en estos reinos [...]

Percebe-se, consultando a documentação da época, que os europeus desconheciam completamente a geografia do território por eles conquistado, e, por isso, nas primeiras encomiendas concedidas por Francisco Pizarro houve grande desigualdade em termos de extensão destas, ocasionando uma série de reclamações judiciais. O interessante é que em nenhum desses processos aparecem os vocábulos

de un español encomendero. Se obligaba éste jurídicamente a proteger a los indios que así le habían sido encomendados y a cuidar de su instrucción religiosa con los auxilios del cura doctrinero" (Capdequi, 1941, p.28). Existe muita bibliografia sobre essa complexa instituição, mas merece destaque a obra de Silvio Zavala (1973).

19 ".... la cédula de 26 de marzo de 1546 ordenaba la congregación de los indios con el propósito de reordenar la tierra, desocupando tierras pertenecientes a indios para fundar poblados de españoles y de mestizos. Y esta cédula específicamente introduce la idea de reorganizar la tierra de los indios congregados señalando tierras de labranza, dehesas y montes. De hecho, el impulso dado a las congregaciones de indios a partir de 1550 coincide con varios factores: la caída sostenida de la población indígena; las primeras crisis de abasto de las ciudades de españoles provocadas por la disminución de la producción indígena, y la disminución del tributo indigena" (Menegus, 1991, p.31). 
ayllu ou etnia, só são mencionados os curacas como senhores de povoados. De qualquer maneira, houve cronistas que perceberam a existência de grandes grupos étnicos que foram desmembrados pela coroa, por causa da necessidade de satisfazer inúmeros candidatos a recompensas pelos serviços prestados. Como exemplo disso, frei Domingo de Santo Tomás, que se queixou ao rei e ao Conselho das Índias sobre o regime colonial, que não respeitava a organização dos grupos sociais indígenas existentes. Por ser grande conhecedor da língua quechua, ele mostrou que existia uma série de etnias que depois da conquista foram aleatoriamente desarticuladas e transformadas em pequenos povoados pelos encomenderos.

[...] y porque mejor vuestra alteza lo entienda, sepa que un pueblo y provincia que hera de dos o três mil vezinos y otros mayores y otros menores tenía un cacique principal y otros dos o tres o quatro caciques menos pricipales y subjetos al mayor y principal, la qual provincia estaba toda mezclada y los indios casados unos con otros, $y$, como heran todos subjetos y inmediatos a los otros caciques principales, tratávanse todos y comunicábanse como hermanos en las comidas y contrataciones [...]

[...] Mire vuestra alteza, el señor que tenia debaxo de si mill o dos mill indios, y se les reparten, que le dexan cinquenta y sesenta indios ¿qué sentirá? Y lo que más es de llorar ¿̇ué sentirán los pobres indios que se veian ser todos una misma cosa y debaxo de un señor y se veen agora de tantos y tan divididos? [...] (Chavez, 1943-1947, p.195-7)

Podemos assim entender quão danosa foi para os grupos étnicos essa divisão inicial realizada pelos conquistadores espanhóis, pois sua organização social foi totalmente desrespeitada. O importante para fazer os repartimientos era saber quantos índios havia à disposição e quais os seus curacas.

Yten terneis cuidado e ansi uos los mandamos que sepais las parcialidades que hay en la tierra de cada cacique e quel es el que mas manda e si las tuviere asentareis por si cada parcialidad con sus indios aparte con el cacique que la mandare e pondréis por escripto quanto ay de vna a otra e quantos indios tiene porque si se hubiere de partir el cacique en dos personas 
sepamos como se a de dividir y se escusen pleitos entre los pobladores e sin ellos puedan mejor servir a su majestad y entender en la población de la tierra. (Levillier, 1921, p.21-2)

Nos primeiros momentos da dominação espanhola, os índios deviam prestar serviço pessoal nas terras de seu encomendero, como no caso dos primeiros repartimientos feitos por Francisco Pizarro. Porém, em 1542 a coroa promulgou as Nuevas Leyes ${ }^{20}$ e suprimiu esse serviço pessoal indígena e o transformou em obrigação para com o encomendero, mas, desta vez, em forma de tributo pago anualmente. O encomendero, por sua vez, tinha o comprometimento de doutrinar os índios na fé cristã. A cédula enviada por Carlos V autorizando a reformulação das encomiendas, que, em geral, eram de tamanho excessivo, ocasionou uma série de processos que se estenderam por anos. Como exemplo, podemos citar o caso de Melchor Verdugo, soldado que acompanhou Francisco Pizarro, que perdeu uma terça parte de suas terras, ${ }^{21}$ e, mesmo depois de sua morte, a viúva deu prosseguimento ao processo. Para tal, foram feitas novas visitas na região de Cajamarca entre 1571-1572 e 1578. A visita conseguiria o número de índios, o valor do repartimiento na época em

20 No Peru, os conquistadores estavam alheios às discussões em defesa dos índios e sentiram as Nuevas Leyes apenas como uma intolerável interferência da coroa. Para eles, a América era terra de conquista, e à classe que haviam combatido correspondiam os privilégios e as responsabilidades do poder. A massa de trabalhadores deveria colocar seus esforços a serviço das castas superiores. As Nuevas Leyes atentavam, dessa forma, contra essa organização porque livravam os servos da dominação direta dos encomenderos, que lutavam pela perpetuação das encomiendas (Villaseñor, 1975, p.34-5).

21 "E ansi visto que por el dicho señor gobernador la dicha visitación e como por ella paresce tener el dicho repartimiento de Caxamalca los dichos tres myll e quatrocentos e noventa e tres indios e que es exçeçibo repartimiento e muncho numero de indios e como excesivo repartimiento de la dicha cedula e provisión real de su Majestad e reformando el dicho repartimiento de Caxamalca apartava e aparto sacava e saco del por via de reformacion myll indios de visitación en las parcialidades e en los indios que cada una dellas se visitaron hasta cumplir el dicho numero de los dichos myll indios" (Archivo General de Indias, Justicia, leg.415, n.2, f. 200v, 1540). 
que Pizarro o encomendou a Melchor Verdugo, bem como o seu valor quando Vaca de Castro reformou a encomienda e, por fim, o valor desta na época da visita. No expediente dessa visita, encontram-se esse processo e, como provas, a cédula de encomienda de Pizarro, a visita de Cristóbal de Barrientos de 1540, a relação de reforma das encomiendas e finalmente a visita de 1571-1572 e 1578. Essa visita foi colocada por Francisco de Toledo ao encargo de Diego Velázquez de Acuña em 1571, mas não pode ser confundida com a Visita General del Peru ordenada por ele. Como só tinha cento e cinquenta dias para realizá-la, Diego Velázquez não a terminou, e, por isso, foi prosseguida em 1578 por Diego de Salazar (Canseco \& Remy, 1992, p.39-44). Processos como este há em demasia nos arquivos espanhóis referentes ao final do século XVI e a todo o XVII. Embora o resultado deles não seja o que nos interessa, podemos afirmar que se trata de importantes documentos para entendermos a organização social indígena, pois, apesar de não mencionarem os ayllus, oferecem, por vezes, características relativas a eles.

Nessas divisões e expropriações, os ayllus que estavam integrados a unidades maiores de caráter político, as quais eram denominadas parcialidades ou suyus, foram desarticulados acabando com a coletividade de propriedades indígenas. $\mathrm{Na}$ costa e nos vales, onde os espanhóis fundaram suas cidades, esse acontecimento foi mais marcante, o que não significa que não tenha acontecido algo semelhante na serra.

[...] los corregidores que les cabe por suerte caer em valles calientes donde se coge trigo y maiz hazen muchas sementeras haziendo trabajar a los indios en ellas y quitándoles por fuerça sus tierras y en las tierras y chacaras de españoles siembran tanbien contra la voluntad dellos y no ay contradecir ni decirles nada [...] (Archivo General de Indias, Lima, leg. 140,1609, f.2r)

Diante de tanto abuso por parte dos encomenderos, Carlos V enviou vários documentos numa tentativa de controlá-los mesmo depois das reformas ordenadas em 1542. 
Por cuanto nos somos informados que en las nuestras Indias, islas y tierra firme del mar océano algunos españoles de los que en ellas residen que tienen indios encomendados, porque los caciques de los pueblos que ansí tienen en encomienda se quejan de los tributos demasiados que les llevan y de otros agravios que reciben y ansimismo porque acogen en sus pueblos religiosos que les enseñen la doctrina cristiana y adviertan de lo que les conviene, diz que les buscan achaques y cosas por donde los destruir y hacer todo el daño que puedan, y ansí sin causa justa hacen pedimientos y ponen acusaciones a los tales caciques ante las justicias ordinarias, las cuales por complacer a los dichos españoles privan a los tales caciques de sus cacicazgos no se pudiendo ni debiendo hacer de derecho, y queriendo proveer en ello [...] (Archivo General de Indias, Indiferente, leg. 424, libro 21, f.35v, 1547, f.35v)

Tais documentos serviram apenas para chamar a atenção dessa situação, mas não conseguiram revertê-la. Guaman Poma de Ayala (1993, p.343) chama a atenção para isso ao afirmar que, por causa dos encomenderos, padres e demais espanhóis, a terra estava ficando despovoada e o rei ficaria pobre, pois os índios tinham perdido chácaras, pastos, mulheres e filhas, e isso estava acarretando um número enorme de processos e gerando grande descontentamento por parte dos indígenas que não queriam mais trabalhar.

Entretanto, Juan de Matienzo (1967), que foi um defensor da perpetuação da encomienda, ao contrário de Guaman Poma de Ayala (1993) e de Polo de Ondegardo (1916, 1990), por exemplo, assinala que seria uma temeridade o não prosseguimento das encomiendas, visto que os índios fugiriam dos campos e toda a colônia ficaria despovoada. Para ele, os índios dependiam dos encomenderos até para comer, e aqueles que tinham algum tipo de comércio ou suas próprias chácaras, na falta de compradores para seus produtos, também iriam embora. Tudo isso junto significaria um grande prejuízo para a coroa. Além disso, para Matienzo (1967, p.98-9), reduzir os índios a um determinado local seria fundamental para poder cristianizá-los, protegê-los e utilizar a sua mão de obra. Tal necessidade era urgente, pois, após a ascensão de Felipe II ao trono em 1556, a falência do império se fez visível, o que causou a necessidade de 
conseguir ingressos que poderiam ser alcançados até com a venda da perpetuidade das encomiendas.

Hernando de Santillán (1968, p.121) critica severamente os encomenderos e descreve todas as atrocidades que praticavam contra os índios para deles conseguirem não só o serviço pessoal, mas principalmente ouro e prata. Obrigavam os curacas a conseguir grandes quantidades desses metais preciosos, o que, por ser impossível, levou ao suicídio de muitos deles, que se viam humilhados pelos espanhóis e sem ter como escapar a tal suplício.

Em sua crônica, Titu Cusi Yupanqui (1992, p.64) relata um confronto que teve com um encomendero vizinho por posse de índios fugitivos. Esses índios haviam sido maltratados pelo encomendero e, por isso, se refugiaram nas terras de Titu Cusi, que os protegeu. Esse fato gerou grande revolta por parte do encomendero, que ameaçou Cusi de invadir suas terras e guerrear violentamente. Titu não se amedrontou e foi ao encontro dele, que não apareceu, e, assim, acabou por tomar conta de mais de quinhentos índios, que agora estavam a salvo da exploração do encomendero. Histórias como essas são comuns, principalmente durante o século XVI, em que encomenderos viviam disputando a posse de terras e índios. A exploração da mão de obra indígena era tão excessiva que assustou muitos espanhóis, que chegaram a escrever sobre isso ao rei.

[...] todos los pueblos de encomenderos es lastima ver de la manera que lo passan porque toda la vida estan ocupados los indios en hilar texer la ropa de la tassa que estan obligados a pagarles tienen en esto los encomenderos tanto señorio que ansi mandan a todos los indios mas que si fueran sus esclavos [...] (Archivo General de Indias, Lima, leg. 140, f.9v, 1609)

O tributo que era cobrado aos índios era demasiado, e Polo de Ondegardo alertou para o fato de que isso causou um número maior de processos, porque antes os índios plantavam nas terras do Inca e do Sol, e agora, desde que encontraram as minas de Potosi, não tinham mais essa obrigação. Sendo assim, acharam que tinham o di- 
reito de plantar a terra para si mesmos e passaram fazê-lo até em terras de outras comunidades.

[...] e de aqui resultan tantos pleytos e diferencias porque algunos pueblos salían a sembrar por los dichos efectos em comarcas de los otros por diferentes rrespectos, e por aver muchos indios o poca tierra [...] (Ondegardo, 1916, p.76-8)

Esse abuso na cobrança de tributo se deveu à ganância dos encomenderos, que nunca estavam satisfeitos. As ordens de Carlos V eram de não maltratar os índios, e, quanto ao tributo a ser cobrado, deveria ser de acordo com as possibilidades do grupo, de maneira a não colocar em risco a vida dos índios nem molestá-los (Libro de cabildos, 1935, p.56, 65). ${ }^{22}$ Como essas ordens nunca foram respeitadas, os grupos indígenas foram extremamente prejudicados, levando à queda demográfica e à desarticulação dos ayllus, que agora estavam repartidos em diferentes encomiendas. A desculpa para isso era que os índios habitavam locais de difícil acesso, e, por isso, era necessário reduzi-los em áreas próximas às fazendas ou minas. Porém, reduzir os índios significava fazê-los abandonar suas aldeias, onde estavam localizadas suas terras comunais originais. Assim, as novas cidades estabelecidas juntaram dois, três ou mais ayllus, todos reduzidos a uma só comunidade.

O grande mentor das reduções de índios foi Juan de Matienzo, assessor de Toledo, que elaborou as instruções para realizar esses novos povoados. Eles deveriam ser construídos em locais de terra fértil que tivessem água em abundância e bons pastos para o gado. Em princípio, não se deveriam tomar terras dos índios sem o consentimento destes, ou então outras terras deveriam ser dadas aos índios em troca daquelas de que os espanhóis se apropriassem. Nesses povoados deveriam viver espanhóis e índios, e estes seriam cristia-

22 Juan de Matienzo (1967, p.44) também frisou essa preocupação em não explorar os índios e taxá-los de acordo com o que eles davam ao Inca, para que eles tivessem condições de cuidar de suas famílias e suprir todas as suas necessidades. 
nizados e educados e trabalhariam na construção das casas e demais funções solicitadas pelo chefe do povoado. Os índios deveriam pagar tributo em forma de mita agrícola e mineira, ou seja, trabalhariam durante um determinado tempo nas terras da redução e, no restante do tempo, poderiam se dedicar às suas próprias terras. Foi, então, organizada a Tasa de la visita general de Francisco de Toledo (Toledo, 1975) que tinha por objetivo saber o número de índios tributários, o que tributavam e qual o novo tributo a ser pago. A política de governo de Toledo visava organizar as reduções para que estas fossem depósitos de mão de obra e, assim, acabar com a dispersão indígena, o que também gerou o fim de muitos ayllus. Ele restabeleceu a mita inca, mas só em relação ao trabalho por turnos, pois dessa maneira conseguiu intensificar a produção mineira. Matienzo (1967) e Toledo (1986) tinham consciência da dificuldade que significava colocar suas propostas em prática, já que os encomenderos sempre estiveram acostumados a explorar a mão de obra indígena. Por isso, eles os ameaçaram com a possibilidade de punição, o que não foi de grande valia, pois, mesmo assim, a população indígena continuou sendo alvo de grandes agravos. Os índios que deveriam ser remunerados por seu trabalho raras vezes foram pagos: "[...] guardan estos ganados los yndios por sus ayllus y no se les paga por la guarda dellos cossa alguna y pagan su tassa por entero [...]" (Archivo General de Indias, Lima, leg. 129, f.5r, 1582).

Quando os integrantes de ayllus estavam distantes de seus suyus, por uma razão ou outra, perderam suas terras para os conquistadores, que imediatamente as tomavam para si, adquirindo-as pela força ou via composição com a coroa da Espanha. Esse fenômeno, junto com a mita colonial, acompanhado pelo processo de reduções levou à desestruturação das comunidades indígenas. Os ayllus viveram grandes problemas socioeconômicos durante o período colonial, pois perderam quase tudo o que tinham e foram forçados a trabalhar de graça para os espanhóis. Como a redução era essencialmente inspirada por motivos utilitários, muitos índios foram reduzidos para trabalhar em minas e fazendas de espanhóis. A Coroa espanhola dizia que era justo e razoável que os índios que tivessem sido pacificados e reduzidos 
à obediência e vassalagem também pagassem tributo em reconhecimento ao domínio real e prosseguissem pagando tributo aos seus próprios chefes. A desculpa de doutrinar os índios era o pretexto para o repartimiento e encomienda, pois os índios eram considerados materiais exploráveis e o encomendero recebia o tributo de duas formas, em espécie (dinheiro ou frutas) e em serviços prestados.

As encomiendas e as reduções simbolizaram o método de expropriação das propriedades dos ayllus que escaparam da espoliação inicial de divisão das terras, nas quais ficavam os indígenas trabalhando em troca de comida. No regime inca, os nativos trabalhavam sem remuneração, mas recebiam tudo de que necessitavam, e, no sistema colonial, só lhes era dado o mínimo para o seu sustento.

[...] dijo que el día de hoy tributan a su encomendero en las cosas que se contiene en la tasa en que hay la diferencia que por ello parece y que se reparte este tributo entre casados y los solteros de común a cada indio un tanto que es a un indio casado una manta de algodón y que asimismo en un año le cabe a pagar media fanega de trigo en seis meses y le cabe algunos ovillos de hilo para toldos y costales y pañizuelos y manteles y otras cosas y de esta manera le tributan y que en tiempo del ingá tenían menos trabajo porque las mujeres ni los viejos no trabajaban y les hacían chacaras a los que se ocupaban y trabajaban en le tributo y que al presente trabajan todos [... y que no le dan otra paga más de que cuando trabajan les dan de comer y no otra cosa [...] (Zúñiga, 1972, p.35)

Outro problema que agravou a situação dos ayllus no período colonial foi o fato de os curacas terem passado a se comportar como os espanhóis, de acordo com as palavras de vários cronistas. Guaman Poma de Ayala (1993, p.380, 568) salientou que os curacas faziam amizade com os corregedores, tornando-se compadres, e, de comum acordo, exploravam em demasia a mão de obra indígena. Roubavam tudo o que podiam dos índios, fazendo que estes os temessem.

[...] demas desto hazen los corregidores com el casique principal que le ajunte much a cantidad de ropa de yndios y de yndias pagandosela a quatro pesos valiendo a cinco y médio e a seis y para ajuntar esta cantidad de ropa 
que pide el corregidor es lastima grande ver de la manera que el casique la ajunta porque por fuerça la quita a los yndios e yndias y les paga así esta ropa como los carneros a como el casique quiere de manera que el casique se queda con mucha plata que le va en hecho tambien su prouecho y muchas vezes no les paga nada y se queda el casique con toda esta plata en achaque ques para el corregidor los carneros y ropa que pide y el pobre indio no habla palabra ni pide a su casique plata ninguna porque todos tiemblan del [...] (Archivo General de Indias, leg. 140, ff.2v e 3r, 1609)

Vários processos como esse apontam para a exploração vivida pelos índios em relação não só aos espanhóis, mas também ao seu próprio curaca (cf. Zúñiga, 1967, p.71; Cangas \& Otazu, 1991, p.515), o que significa que se perderam os laços de familiaridade que antes mantinham esse grupo coeso e faziam que todos trabalhassem para o bem comum. O importante a partir do período colonial foi a posse de terra, o acesso às minas e demais atividades lucrativas. No momento em que os curacas começaram a fazer tratos com espanhóis, perceberam que também poderiam lucrar com esse novo sistema e aderiram a ele, mesmo em detrimento de seu próprio ayllu.

O período colonial para os grupos indígenas simbolizou uma troca de relações de domínio, pois, se antes eles pagavam tributo ao Inca, agora pagavam ao encomendero, aos sacerdotes e à coroa. A diferença é que os novos mecanismos de exploração estavam orientados pela lógica acumulativa, enquanto, no tempo dos incas, o trabalho era compensado mediante um sistema de redistribuição de bens, e isso, no período colonial, foi totalmente suprimido. Foi necessário o desenvolvimento de estratégias de adoção e aceitação das instituições espanholas por parte dos indígenas, que as reinterpretaram segundo seus próprios modelos. Os cronistas indígenas demonstram isso em suas obras, que se tornaram instrumentos de diálogo com o mundo hispânico. O ayllu colonial é um exemplo dessa adaptação, que se tornou necessária ante a planificação espanhola que contemplava o vínculo territorial acima do consanguíneo. 


\section{"Y no hay remedio en este reino"}

Que los mayordomos se hacen justicia, y prenden y castigan y los encierran en sus despensas y en sus casas a los indios y a las indias; también piden media docena de mitayos y media docena de mitayas, y le hacen hilar $y$ tejer, $y$ tienen panaderas, chicheras y pulperas, y muchos yanaconas $y$ chinas, muchachos, cocinera, ama, despensera y mucho aparato, de esto se huelga el encomendero, corregidor, padre, antes le deposita a las indias a su casa, y así se hacen grandes putas, y así no multiplican los indios y no hay remedio en este reino. (Ayala, 1993, p.417)

Guaman Poma de Ayala (1993) expressa com suas palavras um exemplo de contradição e de discurso que se encontra na fronteira das representações de dois mundos, o espanhol e o indígena. Isso é explicável, na medida em que sabemos que ele é oriundo de uma etnia outrora subjugada pelos incas e ao mesmo tempo um homem que foi criado e educado por espanhóis. Se, por um lado, suas raízes o levam a denegrir a imagem dos incas e, desse modo, a legitimar a conquista espanhola, por outro, diante das discrepâncias coloniais, ele usa o discurso indígena para defender os direitos dos povos andinos diante desse "outro" tão ou mais destrutivo que os antigos incas.

$\mathrm{O}$ processo de resistência adaptativa que os indígenas viveram fica visível nas crônicas quando pesquisamos as representações do ayllu, pois nelas transparece a continuidade cultural ocorrida na história desses povos, que, mesmo tendo passado pelo processo de conquista, colonização e aculturação durante o século XVI, conseguiram manter suas principais características culturais.

Até 1550, o ayllu constituiu o núcleo de resistência da sociedade indígena ante a colonização espanhola, pois, apesar das mudanças acarretadas pelo domínio dos brancos, os índios prosseguiram com suas crenças e seus costumes. Com a morte de Atahualpa, acabou o culto oficial ao Sol e ao Inca, mas eles ainda tinham as suas huacas para adorar (Wachtel, 1976a, p.210). Como vimos, durante o governo do vice-rei Toledo, os índios foram obrigados a deixar seus locais de origem e ir viver em aldeias, onde a priori os evangelizadores 
os podiam doutrinar. Muitos ayllus foram reagrupados aleatoriamente, passando a compor as reduções.

Os índios tiveram seu mundo desestruturado, pois os espanhóis implantaram uma série de setores administrativos que tinham por fim prosseguir com seu sistema de colonização. ${ }^{23}$ Depois de prestarem serviços pessoais por muito tempo aos encomenderos, os índios passaram a ter que pagar tributo em dinheiro. Aqueles que não estavam "encomendados" a ninguém foram então reunidos nas reduções como já verificamos.

$\mathrm{O}$ aparato administrativo espanhol serviu para controlar índios e espanhóis, pois uns trabalhavam e outros tinham tendência a querer ganhar mais do que deviam. Para que os índios não fossem explorados, foram criadas diversas leis, como as que aparecem na obra de Matienzo (1967) do período do vice-rei Toledo. Mas, para que estes não deixassem de pagar os tributos, existiam leis e castigos que os forçavam a cumprir com seus deveres em relação à coroa de Castela.

O século XVI teve grande significado para a população indígena, pois seu mundo social, político e religioso foi abalado. Mas algumas características inerentes a esse povo não se apagaram, e, por isso, apesar dos agravos sofridos, os índios mantiveram seu mundo simbólico e, por meio de suas crenças, perpetuaram hábitos antigos, como a organização em ayllus. Mesmo tendo sido reduzidos em povoados, alguns grupos conseguiram manter suas relações por parentesco, seus costumes e, obscurecidas, mas presentes, suas crenças religiosas. Tudo isso em relação ao ayllu, pois as ligações existentes por meio dessa estrutura eram tão sólidas que, mesmo sendo separados, os integrantes de um ayllu nunca perderam tais referências.

O resultado da colonização foi descrito pelos cronistas, que chamaram a atenção principalmente para o abuso na cobrança de tributos e para a mortalidade indígena. Polo de Ondegardo (1916) foi um

23 "Estos castellanos, siguiendo conscientemente los pasos de los romanos, primero tenían que conquistar, después colonizar y por último organizar, gobernar y explotar sus conquistas" (Elliot, 1990, p.30). 
grande jurista e, por isso, recomendou que se conhecessem bem os costumes indígenas para saber como governá-los. Embora tenham sido feitas várias visitas para conhecer esses povos e muitos cronistas os tenham descrito conforme informações coletadas junto aos grupos étnicos, mesmo assim a colonização gerou grandes mudanças no mundo andino. O próprio Polo de Ondegardo (1916, p.60, 82) foi um dos que mais apontaram os abusos cometidos pelos espanhóis, mostrando que, na época dos incas, os velhos, os doentes, as mulheres e as viúvas não entravam no cômputo tributário. Além disso, os índios foram prejudicados de duas maneiras, uma porque perderam o direito às suas terras e outra porque passaram a pagar tributo acima de suas condições. Tudo isso junto mostrou que: "[...] hicieron mas daño los españoles en solo quatro años, quel Ingá en quatroçientos, porque lo tomaron sin horden [...]" (ibidem, p.103).

$\mathrm{Na}$ visita a Yauyos, o corregedor Diego Davila Brizeño (1965, p.155-6) percebeu a grande queda demográfica ocorrida na região desde a conquista, pois, segundo ele, em tempos de Francisco Pizarro havia ali mais de dez mil índios tributários e, em seu tempo, a região estava reduzida a sete mil. Isso porque a região foi muito molestada na época das guerras civis entre espanhóis, que por ali passavam e levavam parte da população para participar nas suas querelas, além de exigirem muito trabalho agrícola. Cristóbal de Molina (1968, p.77), El Almagrista, também critica a insaciável cobiça dos espanhóis, que só queriam enriquecer à custa dos excessivos trabalhos indígenas. Mandavam-nos plantar em suas chácaras, trabalhar nas minas, no comércio, ser carregadores, pastores, prestar serviço pessoal, enfim tanto trabalho que, segundo Molina, em repartimientos em que antes havia cinco ou seis mil índios sobraram duzentos por causa da sobrecarga de trabalho que lhes era imposta.

Com esse quadro caótico, não foram poucos os cronistas que ansiaram por uma volta ao tempo dos incas como solução para tanta desordem. Martin de Múrua (1986, p.351) elogiou muito o governo inca, mostrando que este soube respeitar a natureza dos povos, criando leis apropriadas, dividindo as terras e os templos de acordo com as necessidades de cada grupo. Para o autor, se os espanhóis fizes- 
sem o mesmo que os antigos incas, os índios trabalhariam bem mais e iriam aumentando em número infinitamente.

O problema é que a antiga ordem dos incas foi pervertida, segundo Hernando de Santillán (1968, p.110), pois, quando encomenderos passaram a eleger curacas dentro de seus repartimientos conforme o seu gosto e não de acordo com os costumes locais, fizeram que esses curacas roubassem e explorassem os pobres índios para poder agradar o encomendero que os fez chefe. A situação era tão alarmante que muitos índios se alugavam a espanhóis na tentativa de perfazer o montante necessário para pagar o tributo a eles exigido. Tantos constrangimentos e ainda o fato de muitas vezes terem que trabalhar em locais prejudiciais à saúde levaram à grande mortalidade indígena (ibidem, p.124, 127).

Francisco Falcon (1867, p.461) mostrou que, no tempo dos incas, o tributo era menor e os índios não tinham de trabalhar tanto, nem dar ao Inca coisa alguma de sua própria chácara, mas lavravam a parte que lhes cabia das terras do Inca e do Sol. O mais importante para o autor é que, além de não se exigir demais como em tempos dos espanhóis, tudo o que era produzido era revertido em proveito dos próprios índios, quando estes necessitassem.

A situação vivida pelos indígenas no período colonial levou à desarticulação dos ayllus, que foram reagrupados nas reduções e de onde muitos indígenas fugiram por causa do excesso de trabalho que lhes era exigido.

[...] los pobres yndios com estas cargas se huyen de sus pueblos de apurados y se van a partes muy remotas a esconder por no poder sufrir tantos trabajos como sus corregidores lês dan y esto es um tanto extremo que no cessan todo el tiempo que son corregidores sino es en acosarlos y chuparles y beuerles la sangre [...] (Archivo General de Indias, leg.140, f.2v, 1609)

Guaman Poma de Ayala (1993, p.753-63) foi o cronista indígena mais fervoroso em suas críticas à conduta dos espanhóis, mostrando, ao longo de várias páginas de sua obra, todos os desmandos por eles cometidos e perguntando ao rei o que fazer se "nesse reino 
não há remédio". ${ }^{24}$ Outros o acompanharam nessas ideias e completaram que tal cobiça só poderia ser obra do demônio, como o escreveu Titu Cusi Yupanqui (1992, p.16). Mesmo diante de tanta perplexidade, o importante é que o mundo indígena não ruiu. Sofreu danos, modificações, adaptações, mas sobreviveu, e isso está confirmado nas crônicas. Esse material que espelha discursos tão distintos nas entrelinhas deixa vislumbrar o resultado da circularidade cultural havida entre índios e espanhóis. O ayllu também se modificou, adaptou-se, resistiu. Muitas das características dos antigos ayllus foram preservadas, embora o período colonial exigisse grupos alocados em territórios conhecidos e bem delimitados. Assim, o que foi meramente uma família extensa, detentora ou não de um território, acabou sendo transformado em espaço territorial com a finalidade de armazenar mão de obra.

A concepção de comunidade medieval que os espanhóis tinham foi transformada em redução na América, e, por isso, os cronistas, desde que tiveram contato com os grupos étnicos andinos, descreveram sua organização segundo os padrões europeus, o que ajudou a compor o quadro de mesclas culturais. Sendo assim, as crônicas representam uma confluência de discursos culturais que transcendem a realidade colonial, pois apresentam vestígios, pensamentos, ideais, conceitos e preconceitos sobre um mundo por se desvendar. $\mathrm{O}$ ayllu aparece representado nas fronteiras discursivas espanholas e indígenas e é fruto das práticas culturais vividas por esses povos ao longo do século XVI.

\section{O ayllu nas fronteiras discursivas}

De acordo com as crônicas, os integrantes de um ayllu podiam habitar em distintas regiões, pois o que unia essa gente dispersa por

24 Na crônica de Guaman Poma de Ayala, há várias partes em que o autor critica os espanhóis, e as aqui mencionadas são apenas um exemplo. 
diferentes campos era a crença de que todos eram filhos do mesmo ancestral a quem cultuavam. Estavam todos sujeitos ao curaca e adoravam seus antepassados, encontrando-se em festas durante o ano. Essas cerimônias eram compostas por sacrifícios de comidas, purificação pessoal, cantos e danças, e as pessoas consumiam grande quantidade de chicha e carne de animais sacrificados. Tais rituais de reciprocidade e redistribuição reforçavam as alianças entre essa gente, criando uma identidade. Alguns cronistas representaram o ayllu como um território, por causa das dificuldades linguísticas e dos modelos de comunidade medieval, que os impeliram a compreender o mundo andino de acordo com uma divisão espacial e não de consanguinidade.

Os cronistas descreveram ainda a importância do curaca, que, além de organizar a mão de obra para servir ao Inca (e depois aos espanhóis), tinha a responsabilidade de manter o culto aos seus antepassados que lhes haviam dado origem. Um curaca era eleito por ser considerado o mais apto, hábil e capaz entre todos os outros candidatos. Pertencia à linhagem dos fundadores do ayllu, o que lhe dava o direito de ser o "dono de índios" (Ramírez, 1996). Como representante do culto ancestral, o curaca visitava sua gente pedindo sua ajuda para organizar a mão de obra com a finalidade de manter os edifícios e espaços dedicados ao culto, cultivar a terra e cuidar dos animais que seriam sacrificados. Por tudo isso, o curaca era considerado algo mais que uma simples autoridade secular e política. Era comum encontrar entre os sujeitos de um curaca pessoas que estavam ligadas a outro curaca, o que é chamado de "territorialidade descontínua" (Canseco, 1985, p.401-21), assunto abordado no Capítulo 3. Embora alguns cronistas tenham tido uma certa dificuldade em tratar desse assunto, com o passar do tempo as crônicas agregaram mais dados a respeito da dispersão dos povos andinos, o que suscitou a necessidade de criação das reduções.

Nos Andes não havia propriedade privada, todos tinham direito de cultivar quanta terra pudessem e o tempo que quisessem. As pessoas só tinham direito exclusivo aos bens que plantavam com a sua semente e sua mão de obra. As casas também pertenciam a quem as 
construía, mas não o terreno onde estavam localizadas. Por causa da falta de propriedade privada, podemos dizer que a população andina antes de 1532 vivia em assentamentos cuja ocupação era descontínua, sendo possível encontrar pessoas de ayllus diferentes compartilhando o mesmo espaço (Ramírez, 2001, p.184).

O poder do curaca era flexível, pois não existia um território com fronteiras estáveis e fixas. Os limites de sua soberania se estendiam até onde se encontravam pessoas de sua linhagem e que aderiam ao seu culto. Por sua vez, estas mudavam de residência de acordo com as necessidades do pastoreio e plantio. Assim, em vez de termos fronteiras fixas como nas definições territoriais que conhecemos, temos "fronteiras sociais" que podiam mudar de ano para ano em razão das atividades econômicas (ibidem, 1985, p.423-42). O ayllu não tinha uma definição geográfica, pois as relações entre seus componentes eram apenas de consanguinidade e rituais.

O que se pode entender por ayllu no começo do século XVI é um conjunto de pessoas que não necessariamente viviam concentradas em um lugar, mas que estavam ligadas por laços de parentesco e de culto a um antepassado comum. Isso está representado nas crônicas que examinamos, que no começo não mencionavam os ayllus por causa do desconhecimento linguístico e do interesse apenas por número de pessoas disponíveis para o trabalho a serem divididas entre os espanhóis. Porém, aos poucos os cronistas começam a ser interessar pela cultura do "outro", e vão surgindo verdadeiros estudos etnográficos, como os de Cieza de León e Juan de Betanzos e, posteriormente, os de Polo de Ondegardo, Cristóbal de Molina, Sarmiento de Gamboa, o Jesuita Anónimo e Garcilaso de la Vega. Como já mencionamos em outras partes de nosso trabalho, os cronistas espanhóis costumavam basear-se em seus próprios modelos para interpretar o mundo andino, e no caso do ayllu não foi diferente. Essa estrutura indígena foi equiparada à comunidade camponesa do medievo europeu, que tinha por base o domínio de um espaço territorial. Laços de consanguinidade só foram importantes até o final do período romano, depois disso as estruturas sociais se organizavam geograficamente. Essa visão de mundo foi utilizada na inter- 
pretação do ayllu, e, a partir disso, percebemos dois fenômenos que ocorrem paralelamente na história dos Andes. Por um lado, temos os discursos iniciais dos cronistas representando estruturas indígenas de acordo com suas familiaridades e com tendência a recriar esse mundo de modo a que se torne adequado às necessidades coloniais; por outro, as práticas culturais entre espanhóis e índios, que efetivamente mudaram o curso da história andina. Esses fenômenos em conjunto foram originando as transformações do ayllu, que de sistema de parentesco foi convertido em espaço territorial, conforme afirmamos desde o começo de nosso estudo. Sendo assim, a concepção fluida de ayllu mudou depois da chegada dos espanhóis como resultado das confluências discursivas e culturais vivenciadas pelos dois povos. Quando apareceram as crônicas redigidas por indígenas, o processo de modificação do ayllu já estava consolidado, pois estes só escreveram no final do século XVI e início do XVII. Mas essas obras foram essenciais para compararmos as representações do ayllu aos olhos de europeus e de indígenas e conhecermos mais características dessa estrutura em tempos incaicos. A importância do sistema de parentesco foi salientada por eles, pois é a partir dele que os homens andinos organizam sua vida social, econômica, política e religiosa, assim como conseguem ter direito à terra e a todos os recursos para subsistência dos grupos étnicos. Desse modo, nas crônicas indígenas aparecem todos os mecanismos de organização interna dos ayllus, como vimos anteriormente, e, com base nisso, esses cronistas lutam por seus direitos diante do espanhol usurpador e responsável pelas grandes perdas vividas pelos povos andinos. Já os cronistas que compreenderam tais mecanismos tentaram mostrar para seus compatriotas o quanto é importante respeitar os costumes indígenas para melhor administrá-los, como o fez Polo de Ondegardo. Outros viram na dispersão indígena um fator negativo para o sistema colonial e, por isso, engendraram planos para contornar essa situação, surgindo assim as reduções implantadas durante o governo de Francisco de Toledo e planificadas por Juan de Matienzo.

As representações encontradas nas crônicas simbolizam dois mundos que se encontram em fronteiras discursivas bem perceptí- 
veis, mas que permitem o entrecruzamento de ideias inerentes a essas duas culturas. É possível distinguir os diferentes discursos e os interesses que levaram à sua produção, além de conseguirmos vislumbrar o resultado desse encontro/desencontro cultural que afetou o mundo indígena e transformou o ayllu pré-hispânico. O discurso junto com a prática colonial transformou o ayllu em estrutura beneficiadora de interesses espanhóis e indígenas. Os primeiros privilegiaram a divisão espacial em detrimento da parental para poder usufruir da mão de obra indígena e acabar com descontinuidade territorial de difícil administração. Já os segundos encontram-se divididos em dois grupos. Uns aderiram aos hábitos espanhóis e quiseram adquirir ganhos pessoais, explorando a mão de obra de seus grupos étnicos sem nenhum pudor, passando a ser temidos e odiados. Outros como Guaman Poma de Ayala defenderam seu povo contra os abusos de encomenderos, padres e até mesmo de curacas, utilizando para isso argumentos que revitalizavam antigos costumes indígenas. Nesse caso, o ayllu foi um dos principais temas de discussão, já que é a base organizacional da sociedade andina.

As práticas culturais vivenciadas durante o período colonial foram fundamentais para as mudanças ocorridas com o ayllu, podendo ser exemplificadas não só com o processo inicial de repartimientos, como já vimos, mas também com o processo de evangelização, as doenças introduzidas pelos europeus, que causaram uma baixa demográfica entre os nativos, e a necessidade de facilitar a arrecadação de impostos e organizar a mão de obra. Esses foram alguns dos fatores que em conjunto levaram à implantação da política das reduções (Mansilla, 1997, p.50,54-60). Estas começaram informalmente em 1540 , por causa da mortalidade entre os nativos. Os sobreviventes iam se aglomerando com outros grupos quando suas linhagens se extinguiam (Zúñiga, 1972). A partir da década de 1570, o vice-rei Francisco de Toledo implementou as reduções com o objetivo de aumentar o poder colonial, concentrando integrantes de vários ayllus que viviam dispersos em novos assentamentos passíveis de exploração por parte dos espanhóis. As reduções diminuíram o poder do curaca e acabaram com o culto aos seus antepassados. A conversão 
ao catolicismo significou o fim da identidade como filhos comuns de um único ancestral. Ao deixarem de identificar-se como sujeitos a um curaca e filhos de determinadas huacas, os andinos passaram a identificar-se com um lugar. Esse lugar foi a redução criada para facilitar o controle de um Estado central europeu.

Ao analisarmos as crônicas, visualizamos esse processo que começou com dificuldades de interpretação por causa das questões linguísticas, depois se passou a representar o ayllu como um clã ou um povoado e durante o período toledano o que passou a interessar foram os assentamentos de acordo com o modelo de comunidade europeia. Por isso, ao lermos as crônicas, enfatizamos os discursos que, convergentes ou divergentes ou simplesmente entrelaçados nas fronteiras discursivas, construíram imagens do mundo andino, que podem, por sua vez, ser explicadas historicamente. Essas imagens não foram apenas fruto dos esforços feitos por europeus, nativos e mestiços para representar esse mundo por meio dos textos, mas também expressões do pensamento que surgiu de uma nascente modernidade ou de uma cultura e sociedade (a espanhola) que vivia a transição do mundo medieval para o moderno e que tinha por tarefa compreender a realidade americana e construir uma ordem política e social nessas terras (Hurtado, 2001, p.113). 



\section{CONSIDERAÇÕES FINAIS}

Neste trabalho tentamos mostrar as representações de ayllu encontradas em algumas crônicas do século XVI e início do XVII, percebendo que, nas suas fronteiras discursivas conjuntamente com as práticas culturais quinhentistas, nasceu o ayllu colonial que de sistema de parentesco foi transformado em espaço territorial. Analisamos, então, o mundo andino antes e durante as reduções toledanas, momento de consolidação de tais mudanças.

Começamos por esboçar nosso quadro teórico, sem o qual não seria possível analisar as crônicas, pois o conceito de fronteiras discursivas criado à luz da história cultural serviu de norteador nessas leituras. O jogo de alteridade vivido por espanhóis e indígenas está explícito nas páginas de suas obras, cabendo a nós pesquisadores interpretar e reinterpretar essas representações culturais.

Sendo nosso objeto de estudo o ayllu representado nas crônicas quinhentistas, fez-se necessário conhecer um pouco da história da Espanha medieval e moderna e do Tahuantinsuyu. Por isso, apresentamos algumas características da Espanha durante o século XV e retrocedemos no tempo para compreender a evolução da comunidade camponesa que serviu de modelo aos espanhóis nas suas representações do ayllu. Desenvolvemos ainda uma sintética história dos incas para facilitar a compreensão do conteúdo das crônicas e perce- 
ber de que modo os espanhóis se apropriaram das estruturas incas para facilitar o seu sistema de colonização. Um exemplo disso foi a reutilização da mita incaica, que antes era o tributo pago em forma de trabalho para o Estado e que os espanhóis transformaram em tributo pago ao encomendero não só em trabalho pessoal, mas também em espécie e dinheiro. A maior diferença é que no tempo dos incas todos que participavam da mita estatal eram recompensados pela redistribuição de produtos armazenados em depósitos estatais, o que significa que ninguém passava por dificuldades. No período colonial isso mudou, pois os índios passaram a ser explorados de forma desumana e não viam nenhum retorno de seu trabalho, o que levou ao descontentamento geral que não apenas originou movimentos de resistência, mas também levou a atos de desespero como as bebedeiras e o suicídio de muitos.

Os estudos atuais sobre o ayllu pouco utilizaram as crônicas, e, por isso, estas são a base de construção de nosso trabalho. Embora tenhamos utilizado seus conteúdos ao longo de todo o nosso estudo, o objetivo principal foi mostrar as representações das características do ayllu que aparecem nessas obras. Percebemos, no entanto, o quanto é difícil conjugar discursos com práticas culturais, visto que nem sempre sabemos quando um corresponde ao outro ou vice-versa. As crônicas são um aglomerado de informações que podem ser intencionais ou simples constatações, podem ser relatos etnográficos ou ainda fruto de total incompreensão do novo. Por isso, para interpretá-las, foi necessário ter em mente que elas expressam apenas representações de um cotidiano vivido por homens com concepções de mundo distintas.

As mudanças ocorridas com o ayllu foram engendradas ao longo das primeiras décadas de colonização espanhola para satisfazer ao mecanismo colonial. Primeiro, houve uma certa dificuldade em se entender o significado dessa estrutura indígena, o que mostramos por meio da análise de alguns dicionários da época. Essa confusão inicial misturada ao desinteresse em compreender essa estrutura originou representações cronísticas diversas, resultantes das adaptações do ayllu às necessidades dos conquistadores. Assim, comprovamos 
que nas crônicas destacou-se a importância da divisão espacial, embora os nossos cronistas tenham sabido descrever a forma como os incas dividiam e administravam o Tahuantinsuyu por meio do sistema decimal analisado anteriormente. Porém, essa divisão era pautada na principal característica de organização dos povos andinos, que se dava pela consanguinidade, algo relevado pelos espanhóis, que perceberam que esse sistema traria problemas para o seu modo de administrar o trabalho indígena. A estes interessava que os índios estivessem reunidos num só local para atender às necessidades produtivas dos encomenderos e da coroa. Por meio das reduções toledanas, isso se tornou possível. Os índios passaram a habitar nas terras a serem plantadas ou nas regiões de exploração mineira, dois grandes setores de produção necessários aos colonizadores e à metrópole.

Percebemos então que os cronistas representaram esse conjunto de práticas culturais, aclarando a forma como o ayllu foi sendo adaptado às necessidades coloniais. A influência do modelo europeu de comunidade camponesa nos primeiros escritos sobre o ayllu e as dificuldades linguísticas foram fundamentais para que as representações iniciais dessa estrutura estivessem vinculadas à ideia de que um grupo de pessoas se articula de acordo com o espaço territorial em que habita e do qual tira o seu sustento. Com o tempo, os cronistas se deram conta de que a organização dos grupos étnicos andinos não correspondia a esse modelo. Embora tenham entendido posteriormente a vinculação por laços de parentesco desses grupos, o sistema colonial exigia a organização espacial da mão de obra disponível. Então, as crônicas passaram a representar o ayllu com características incaicas, ou seja, com base no sistema de parentesco, mesclado à nova roupagem adquirida no conjunto das práticas culturais coloniais, em que o território passa a ser o principal ponto de coesão dos grupos étnicos inseridos no sistema de reduções toledanas, capaz de satisfazer a todas as necessidades de espanhóis e também de alguns indígenas, como é o caso dos curacas que passaram a usufruir da mão de obra indígena para benefício pessoal.

Na confluência dos discursos dos cronistas, visualizamos essas mudanças que são oriundas de um fenômeno discursivo em conjun- 
160 ANA RAQUEL PORTUGAL

to com práticas culturais ocorridas durante todo o século XVI. Esse entrecruzamento de discursos e práticas quinhentistas deu origem ao ayllu colonial. 


\section{REFERÊNCIAS BIBLIOGRÁFICAS}

ACOSTA, J. de. Historia natural y moral de las Indias. In: Obras del Padre Jose de Acosta. Madrid: Biblioteca de Autores Españoles, 1954. ALBERTI, G.; MAYER, E. (Comp.) Reciprocidad e intercambio en los Andes peruanos. Lima: Instituto de Estudios Peruanos, 1974. (Peru Problema, 12).

ALMEIDA, M. R. C. de. Os índios aldeados no Rio de Janeiro colonialNovos súditos cristãos do Império Português. Campinas, 2000. Tese (Doutorado) - Universidade Estadual de Campinas.

ANAVITARTE, C. N. El ayllu y la marca en el antiguo Peru. Cuzco: Garcilaso, 1965.

ANTON, F.; DOCKSTADER, F. J. L'Amérique précolombienne. Trad. Dominique Bleler. Lausanne: Éditions Rencontre, 1969. (L'Art du Monde, 2).

ARCHIVO GENERAL DE INDIAS. Justicia, leg. 415, 1540; Indiferente, leg. 424, 1547; Lima, leg. 129, 1582; Lima, Cartas y expedientes de personas seculares, leg.140, 1609.

ARGUEDAS, J. M. Las comunidades de España y del Perú. Lima: Universidad Nacional Mayor de San Marcos, 1968.

ARRIAGA, P. J. de. Extirpación de la idolatría del Pirú. In: Crónicas peruanas de interés indígena. Madrid: Biblioteca de Autores Españoles, 1968. v.209.

ARTOLA, M. Enciclopedia de historia de España. Madrid: Alianza Editorial, 1991. v.5. 
ATTALI, J. 1492. Lisboa: Teorema, 1991.

ÁVILA, F. de. Dioses y hombres de Huarochirí. Trad. José María Arguedas. Lima: Instituto de Estudios Peruanos, 1966.

Ritos y tradiciones de Huarochirí. Manuscrito quechua de comienzos del siglo XVII. Trad. Gerald Taylor. Lima: Instituto de Estudios Peruanos, Instituto Francés de Estudios Andinos, 1987.

AYALA, F. G. P. de. Nueva corónica y buen gobierno. Lima: Fondo de Cultura Económica, 1993. 3 t.

AZANCOT, P. A. V. Los conquistadores y la ruptura de los ecosistemas aborigenes. In: SOLANO, F. et al. Proceso histórico al conquistador. Madrid: Alianza Editorial, 1988.

BAKHTIN, M. A cultura popular na Idade Média e no Renascimento: o contexto de François Rabelais. 2.ed. São Paulo: Hucitec; Brasília: Editora UnB, 1993.

BALBOA, M. C. Miscelánea antártica. Lima: Universidad Nacional Mayor de San Marcos, 1951.

BARRENECHEA, R. P. Mito, tradicción e historia del Peru. 3.ed. Lima: Retablo de Papel, 1973.

. Los cronistas del Peru. Lima: Banco de Credito del Peru, 1986. Prologo. In: HOLGUIN, D. G. Vocabulario de la lengua general de todo el Perú llamada quichua o del inca. 3. ed. Lima: Universidad Nacional Mayor de San Marcos, 1989.

BARRIENTOS, C. de. Translado autentico de la visita que hizo el señor Cristobal de Barrientos a las siete guarangas de la provincia de Caxamarca, por orden del señor gobernador Don Francisco Pizarro, el 24 de agosto del año pasado de 1540. In: SORIANO, W. E. El primer informe etnológico sobre Cajamarca, Año de 1540. Revista Peruana de Cultura (Lima), n.11-12, 1967.

BAUDIN, L. El imperio socialista de los incas. Santiago: Zig-Zag, 1945. BEALS, R. L.; HOIJER, H. An introduction to anthropology. New York: The Macmillan Company, 1956.

BENZONI, G. Historia del Nuevo Mundo. Madrid: Alianza Editorial, 1989.

BERNAND, C. (Comp.) Descubrimiento, conquista y colonización de América a quinientos años. México: Consejo Nacional para la Cultura y las Artes, Fondo de Cultura Económica, 1994.

BERTONIO, L. Vocabulário de la lengua aymara. Cochabamba: Ceres, 1984. 
BETANZOS, J. de. Suma y narración de los Incas. In: Crónicas peruanas de interés indígena. Madrid: Biblioteca de Autores Españoles, 1968. v.209.

BHABHA, K. K. Narrando a Nação e DissemiNação: tempo, narrativa e as margens da nação moderna. Trad. Glória Maria de Mello Carvalho. Belo Horizonte, 1995. (Mimeogr.)

BLOCH, M. Sociedade feudal. Lisboa: Edições 70, 1982.

BONILLA, H. El sistema colonial en la America española. Barcelona: Editorial Crítica, 1991.

BRIZEÑO, D. D. Descripcion y relacion de la provincia de los Yauyos. In: Relaciones geográficas de Indias. Madrid: Biblioteca de Autores Españoles, 1965. t.I.

BURKE, P. Abertura: a nova história, seu passado e seu futuro. In: . (Org.) A escrita da história: novas perspectivas. São Paulo: Editora UNESP, 1992a.

A história dos acontecimentos e o renascimento da narrativa. In: (Org.) A escrita da história: novas perspectivas. São Paulo: Editora UNESP, 1992b.

. A Escola dos Annales (1929-1989): a Revolução Francesa da historiografia. 2.ed. São Paulo: Editora UNESP, 1992c.

Variedades de história cultural. Rio de Janeiro: Civilização Brasileira, 2000.

CAMPO, J. E. del. Relaciones de los Vireyes y Audiencias que han gobernado el Peru. Lima: Imprenta del Estado, 1867. Tomo I: Memorial y Ordenanzas de D. Francisco de Toledo [1575].

CAMPOS, P. M. P. de. As marcas do poder: inquisição e normatização no início da época moderna. Praia Grande (Niterói), ano II, n.1, 1998, CANGAS, D. D. de; OTAZU, B. de. Visita de los valles de Sonqo en los yunka de coca de La Paz, 1568-1570. Madrid: Instituto de Cooperación Iberoamericana, Sociedad Estatal Quinto Centenario, Instituto de Estudios Fiscales, 1991.

CANSECO, M. R. de D. Las etnias del valle del Chillón. Revista del Museo Nacional (Lima), t.38, 1972.

Reflexiones sobre la reciprocidad andina. Revista del Museo Nacional (Lima), t.XLII, 1976.

Etnía y sociedad. Costa peruana prehispánica. Lima: Instituto de Estudios Peruanos, 1977. (Historia Andina, 4). 
Señorios indígenas de Lima y Canta. Lima: Instituto de Estudios Peruanos, 1978a. (Historia Andina, 7).

. Estructuras políticas y económicas de la costa central del Perú precolombino. Revista Histórica (Lima), t.XXXI, p.203-18, 1978b.

La voz parcialidad en su contexto en los siglos XVI y XVII. In: CASTELLI, A. et al. Etnohistoria y antropología andina. Lima: Centro de Proyección Cristiana, 1981.

Estructuras andinas del poder. Lima: Instituto de Estudios Peruanos, 1983.

. Patronyms with the consonant F. In: MASUDA, S. et al. Andean ecology and civilization. Tokyo: University of Tokyo Press, 1985.

Historia del Tahuantinsuyu. 2.ed. Lima: Instituto de Estudios Peruanos, 1988a. (Historia Andina, 13).

. La mujer en la época prehispánica. Lima: Instituto de Estudios Peruanos, 1988b. (Documento de Trabajo,17).

Estructuras andinas del poder. Ideología religiosa y política. 3.ed. Lima: Instituto de Estudios Peruanos, 1988c. (Historia Andina, 10). CANSECO, M. R. de D. Costa peruana prehispánica. 2.ed. Lima: Instituto de Estudios Peruanos, 1989. (Historia Andina, 15).

. Ensayos de historia andina: élites, etnías, recursos. Lima: Instituto de Estudios Peruanos, 1993. (Historia Andina, 20).

CANSECO, M. R. de D.; REMY, P. Las visitas a Cajamarca. 1571-1572/1578. Lima: Instituto de Estudios Peruanos, 1992.

CAPDEQUI, J. M. O. El estado español en las Indias. México: El Colegio de México, 1941.

CARDOSO, C. F. S. A cidade-Estado antiga. São Paulo: Ática, 1985. CASTELLI, A. et al. Etnohistoria y antropología andina. Lima: Centro de Proyección Cristiana, 1981.

CASTILLO, G. C. del. Raices peninsulares y asentamiento indiano: los hombres de las fronteras. In: SOLANO, F. et al. Proceso histórico al conquistador. Madrid: Alianza Editorial, 1988.

. Las fronteras de Europa en la Edad Moderna. In: . Ensayos sobre los reinos castellanos de Indias. Madrid: Real Academia de Historia, 1999.

CASTRO POZO, H. Nuestra comunidad indígena. Lima: Editorial "El Lucero", 1924. 
Social and economic-political evolution of the communities of central Peru. In: STEWARD, J. H. Handbook of South American Indians. New York: Cooper Square Publishers, 1963. v.II.

Del ayllu al cooperativismo socialista. Lima: Peisa, 1973.

CELESTINO, O.; MEYERS, A. La posible articulacion del ayllu a traves de las cofradías. In: CASTELLI, A. et al. Etnohistoria y antropología andina. Lima: Centro de Proyección Cristiana, 1981.

CHARTIER, R. A história cultural: entre práticas e representações. Lisboa: Difel, 1990.

Textos, impressão, leituras. In: HUNT, L. A nova história cultural. São Paulo: Martins Fontes, 1992.

CHAVEZ, E. L. La iglesia de España en el Perú. In: Colección de Documentos para la Historia de la Iglesia en el Perú. Sevilla: s. d., 1943-1947. t.I.

CIEZA DE LEÓN, P. de. Crónica del Perú. Lima: Pontificia Universidad Católica del Perú, 1991. 4 v.

COBO, B. Historia del Nuevo Mundo. Madrid: Biblioteca de Autores Españoles, 1964.

COCK, G. El ayllu en la sociedad andina: alcances y perspectivas. In: CASTELLI, A. et al. Etnohistoria y antropología andina. Lima: Centro de Proyección Cristiana, 1981.

COOPER, N. F. Searching for the blank generation: consumer choice in Roman and post-Roman Britain. In: WEBSTER, J.; COOPER, N. Roman imperialism: post-colonial perspectives. Leicester: University of Leicester, 1996.

CORTÁZAR, J. A. G. de. La sociedad rural en la España medieval. 2.ed. Madrid: Siglo XXI, 1990.

CUETOS, M. L. L. La América española, 1492-1898: de las Indias a nuestra América. Madrid: Historia 16, 1996.

CUNEO VIDAL, R. Historia de la civilización peruana. Lima: Prado Pastor, 1977.

CUNOW, H. El sistema de parentesco peruano y las comunidades gentilicias de los incas. Paris: J. A. Encinas e J. A. Jimenez, 1929a. (Biblioteca de Antropología Peruana, 1).

Las comunidades de aldea y de marca del Perú antiguo. Paris: J. A. Encinas e J. A. Jimenez, 1929b. (Biblioteca de Antropología Peruana, 2). 
La organización social del imperio de los incas. Lima: J. A. Encinas, 1933. (Biblioteca de Antropología Peruana, 3).

CURATOLA, M. Dioses y hombres del maiz; religión, agricultura y sociedad en el antiguo Perú. In: CURATOLA, M.; SILVA-SANTISTEBAN, F. (Ed.) Historia y cultura del Peru. Lima: Universidad de Lima, Museo de La Nación, 1994.

DE PAUW, C. Recherches philosophiques sur les Américaine. In: Euvres de Pauw. Paris: s. n., 1768-1769. 3v.

DELUMEAU, J. História do medo no Ocidente: 1300-1800. Uma cidade sitiada. São Paulo: Companhia das Letras, 1989.

DIAZ-PLAJA, F. Historia de España en sus documentos: siglo XVI. Madrid: Catedra, 1988.

DOIG, F. K. El periodo formativo. In: Historia del Peru. 4. ed. Lima: Editorial Juan Mejia Baca, 1982. t.I.

DUBY, G. Guerreiros e camponeses: os primórdios do crescimento econômico europeu. 2.ed. Lisboa: Estampa, 1980.

DURAND, J. La transformación social del conquistador. México: Porrúa y Obregón, 1953. v.I.

DUVIOLS, P. La destruicción de las religiones andinas. México: Universidad Nacional Autónoma de México, 1977.

La dinastía de los incas: monarquia o diarquía? Argumentos heurísticos a favor de una tesis estructuralista. Journal de la Société des Américanistes (Paris), v.LXVI, 1979.

Algunas reflexiones acerca de las tesis de la estructura dual del poder incaico. Historica (Lima), v.IV, n.2, p.183-96, 1980.

EGUIGUREN, L. A. El ayllu peruano y su condición legal. Lima: s. n., 1914.

EICH, D. Ayllú und Staat der Inka: zur Diskussion der asiatischen Produktionsweise. Frankfurt: Vervuet, 1983.

ELLIOT, J. H. O Velho Mundo e o Novo: 1492-1650. Lisboa: Querco, 1984. (Entender, 2).

. La España imperial.1469-1716. Barcelona:Vicens-Vives, 1987. . España y su mundo: 1500-1700. Madrid: Alianza Editorial, 1990.

El Viejo Mundo y el Nuevo: 1492-1650. Madrid: Alianza Editorial, 1997.

ESPEJO, F. C. Cronistas del Peru antiguo. Lima: Editorial Horizonte, 1989. 
ESTETE, M. de. El descubrimiento y la conquista del Perú. In: SALAS, A. M. et al. Crónicas iniciales de la conquista del Perú. Buenos Aires: Plus Ultra, 1987.

EVANS-PRITCHARD, E.-E. Les nuers. Paris: Gallimard, 1968.

FALCON, F. Representacion hecha por el licenciado Falcon en Concilio provincial, sobre los daños y molestias que se hacem a los indios. In: Colección de documentos inéditos del Archivo de Indias. Madrid: Imprenta de Frías y Compañía, 1867.

FERNÁNDEZ DE OVIEDO, G. Historia general y natural de las Indias. Madrid: Biblioteca de Autores Españoles, 1959.

FERNÁNDEZ, M. B. Los campesinos en la sociedad medieval. Madrid: Arco Libros, 1999.

FEVBRE, L. Le problème de l'incroyance au $16^{e}$ siècle: la religion de Rabelais. Paris: Albin Michel, 1988.

FORNET-BETANCOURT, R. Transformación intercultural de la filosofía. Bilbao: Desclée, 2001.

FOSSIER, R. La sociedad medieval. Barcelona: Crítica, 1996.

FOUCAULT, M. A arqueologia do saber. 5.ed. Rio de Janeiro: Forense Universitária, 1997.

História da sexualidade. 8.ed. Rio de Janeiro: Graal, 1998. v.2: O uso dos prazeres.

. História da sexualidade. 3.ed. Rio de Janeiro: Graal, 1999. v.1: A vontade de saber.

História da sexualidade. 6.ed. Rio de Janeiro: Graal, 1999. v.3: O cuidado de si.

FRANCO JÚNIOR, H. A Idade Média: nascimento do Ocidente. 4.ed. São Paulo: Brasiliense, 1992.

FUENZALIDA VOLLMAR, F. Estructura de la comunidad de indigenas tradicional; una hipótesis de trabajo. In: MAR, J. M. (Comp.) Hacienda, comunidad y campesinado en el Perú. 2.ed. Lima: Instituto de Estudios Peruano, 1976. (Peru Problema, 3).

GABAI, R. V. Curacas y encomenderos: acomodamiento nativo en Huaraz - siglos XVI y XVII. Lima: P. L. Villanueva, 1980.

GAMBOA, P. S. de. Historia de los incas. Madrid: Miriguano Editores, 1988.

GARCÍA, S. R. El sistema de parentesco inca. Revista Española de Antropologia Americana (Madrid), v.X, 1980. 
GEERTZ, C. A interpretação das culturas. Rio de Janeiro: Guanabara Koogan, 1989.

GINZBURG, C. Sinais: raízes de um paradigma indiciário. In: Mitos, emblemas, sinais: morfologia e história. São Paulo: Companhia das Letras, 1990.

. Provas e possibilidades à margem de Il ritorno de Martin Guerre, de Natalie Zemon Davis. In: A micro-história e outros ensaios. Lisboa: Difel, 1991a.

. História noturna: decifrando o sabá. São Paulo: Companhia das Letras, $1991 \mathrm{~b}$.

GLAVE, L. M. Trajinantes: caminos indígenas en la sociedad colonial. Siglos XVI-XVII. Lima: Instituto de Apoyo Agrario, 1989.

GODELIER, M. Horizontes da antropologia. 2.ed. Lisboa: Edições 70, 1977. (Perspectivas do homem, 14).

GRUZINSKI, S. La red agujerada - identidades étnicas y occidentalizacion en el Mexico colonial (siglos XVI-XIX). America Indigena (México), ano XLVI, n.3, 1986.

GRUZINSKI, S. Las repercusiones de la conquista: la experiencia novohispana. In: BERNAND, C. (Comp.) Descubrimiento, conquista y colonización de América a quinientos años. México: Consejo Nacional para la Cultura y las Artes, Fondo de Cultura Económica, 1995.

GUIBERNAU, M. Nacionalismos: o Estado nacional e o nacionalismo no século XX. Rio de Janeiro: Jorge Zahar, 1997.

HOFFMANN, C. A. Apuntes históricos sobre la Provincia de Tarma en la Sierra Central del Perú. El Kuraka y los ayllus bajo la dominación colonial española, siglos XVI-XVIII. Bonn: BAS, 1988.

HOFFMANN, C. A. Zur Bedeutung und Gebrauch des Begriffs Ayllu; Neue Erkenntnisse über die innere Funktion eines Beispiels einer Kolonialzeitlichen Dorfgemeinschaft in Tarma/Peru. In: . Beiträge zur Kulturgeschichte des westlichen Südamerika. Bonn: Westdeutscher Verlag, 1990.

. Los títulos de comunidades como fuentes para una reconstrucción histórica de límites de las antiguas etnias andinas: el ejemplo de Tarma en la sierra central del Perú. América Indígena, n.4, 1994.

HOLGUIN, D. G. Vocabulario de la lengua general de todo el Perú llamada quichua o del Inca. 3. ed. Lima: Universidad Nacional Mayor de San Marcos, 1989. 
HOZ, P. S. de. La relación de Pero Sancho. Buenos Aires: Plus Ultra, 1986.

HUNT, L. A nova história cultural. São Paulo: Martins Fontes, 1992. HURTADO, L. R. Denominadores comunes en las críticas y propuestas de "Buen Gobierno" según las crónicas de los siglos XVI y XVII. In: NOEJOVICH, C. H. América bajo los Austrias: economía, cultura y sociedad. Lima: Pontificia Universidad Católica del Perú, 2001.

INSTRUCCIÓN QUE EL MARQUÉS FRANCISCO PIZARRO dio a Diego Verdejo para la visita que había de hacer desde Chiacama hasta Tucome, 1540. In: LEVILLIER, R. Gobernantes del Perú. Cartas y papeles. Siglo XVI. Madrid: Sucesores de Rivadeneyra, 1921, t.1.

ISBELL, B. J. Parentesco andino y reciprocidad. Kukaq: los que nos aman. In: ALBERTI, G.; MAYER, E. Reciprocidad e intercambio en los Andes peruanos. Lima: Instituto de Estudios Peruanos, 1974. (Peru Problema, 12).

JESUITA ANÓNIMO. Relación de las costumbres antiguas de los naturales del Pirú. In: Crónicas peruanas de interés indígena. Madrid: Biblioteca de Autores Españoles, 1968.

KAGAN, R. L. Universidad y sociedad en la España moderna. Madrid: Editorial Tecnos, 1981.

KAMEN, H. Una sociedad conflictiva: España, 1469-1714. Madrid: Alianza Editorial, 1984.

KONETZKE, R. Colección de documentación de la historia de la formación social de hispanoamérica: 1493-1810. Madrid: Consejo Superior de Investigaciones Cientificas, 1953.

KUBLER, G. The quechua in the colonial world. In: STEWARD, J. H. Handbook of South American Indians. New York: Cooper Square, 1963. v.2.

LA BANDERA, D. Relación general de la disposición y calidad de la provincia de Guamanga, llamada San Joan de la Frontera, y de la vivienda y costumbres de los naturales della. Año de 1557. In: LA ESPADA, M. J. de. Relaciones geográficas de Indias. Madrid: Biblioteca de Autores Españoles, 1965. t.I.

LA ESPADA, M. J. de. Prólogo e apéndice I. In: CIEZA DE LEÓN, P. de. La guerra de Quito. Madrid: s. n.,1877. t.I. . De las antiguas gentes del Perú. Madrid, 1892. 
LA ESPADA, M. J. de. Relaciones geográficas de Indias. Madrid: Biblioteca de Autores Españoles, 1965.

LA VEGA, G. de (Inca). Diálogo de amor de León Hebreo. Sevilla: Padilla Libros, 1989.

Comentarios reales de los incas. Lima: Fondo de Cultura Económica, 1991.2v.

LADURIE, Le R. Montaillou: cátaros e católicos em uma aldeia do Sul da França. Lisboa: Edições 70, 1986.

LANDA, D. de. Relación de las cosas de Yucatán. México: Porrúa, 1966.

LAPLANTINE, F. Aprender antropologia. 2.ed. São Paulo: Brasiliense, 1989.

LAS CASAS, B. de. Apologética historia sumaria. Madrid: Biblioteca de Autores Españoles, 1958. v.105 e 106.

LATCHAM, R. E. Los incas sus origenes y sus ayllus. Santiago: Balcells, 1928.

LAVALLÉE, D.; JULIEN, M. Asto: curacazgo prehispánico de los Andes Centrales. Lima: Instituto de Estudios Peruanos, 1983.

LE GOFF, J. Para um novo conceito de Idade Média: tempo, trabalho e cultura no Ocidente. Lisboa: Estampa, 1980. (Imprensa Universitária, n.14).

A civilização do Ocidente medieval. 2.ed. Lisboa: Estampa, 1984.

LEÓN-PORTILlA, M. (Org.) A conquista da América Latina vista pelos índios: relatos astecas, maias e incas. Petrópolis: Vozes, 1984.

LEVI, G. Sobre a micro-história. In: BURKE, P. (Org.) A escrita da história: novas perspectivas. São Paulo: Editora UNESP, 1992.

LEVILLIER, R. Gobernantes del Perú. Cartas y papeles. Siglo XVI. Madrid: Sucesores de Rivadeneyra, 1921. t.1.

LIBRO DE CABILDOS. Años de 1544-1546. Lima: Torres-Aguirre, 1935.

LOCKHART, J. Spanish Peru-1532-1560: a colonial society. London: The University of Wisconsin Press, 1968.

LÓPEZ DE GÓMARA, F. Historia general de las Indias. Madrid: Biblioteca de Autores Españoles, 1946.

LUMBRERAS, L. G. De los pueblos, las culturas y las artes del antiguo Peru. Lima: Moncloa-Campodonico, 1969. Los origenes de la civilizacion en el Peru. 5.ed. Lima: Milla Batres, 1981. (Coleccion el Ande y la vida). 
MANSILLA, R. E. Las comunidades indígenas y la economía colonial peruana. Bilbao: Servicio Editorial de la Universidad del Pais Basco, 1997.

MARAVALL, J. A. Antiguos y modernos. La idea de progreso en el desarrollo inicial de una sociedad. Madrid: Sociedad de Estudios y Publicaciones, 1966.

MARIÁTEGUI, J. C. Sete ensaios de interpretação da realidade peruana. São Paulo: Alfa-Omega, 1975.

MARKHAM, C. The incas of Peru. London: s. n., 1910.

MARMONTEL, J. F. Les incas, ou la destruction de l'empire du Pérou. Lima: Universidad Nacional Mayor de San Marcos. Instituto Francés de Estudios Andinos, 1991.

MARTINS, N. T. A missão como instrumento da colonização da Ibero-América. Estudos Leopoldenses (São Leopoldo), v.24, n.106, p.6, set./ out. 1988.

MARZAL, M. M. Historia de la antropología. 3.ed. Lima: Pontificia Universidad Católica del Perú, 1989. v.I

MASON, J. A. The ancient civilizations of Peru. London: Penguin Books, 1991.

MATIENZO, J. de. Gobierno del Perú. Edition et Etude préliminaire par Guillermo Lohmann Villena. Paris, Lima: Instituto Francés de Estudios Andinos, 1967.

MATOS MAR, J. (Comp.) Hacienda, comunidad y campesinado en el Perú. 2.ed. Lima: Instituto de Estudios Peruanos, 1976a. (Peru Problema, 3).

Comunidades indígenas del área andina. In: (Comp.) Hacienda, comunidad y campesinado en el Peru. 2.ed. Lima: Instituto de Estudios Peruanos, 1976b. (Peru Problema, 3).

MAUSS, M. Sociologia e antropologia. São Paulo: EPU, Edusp, 1974. v.II.

MAYER, E.; BOLTON, R. Parentesco y matrimonio en los Andes. Lima: Pontificia Universidad Católica del Perú, 1980.

MEANS, P. A. Ancient civilizations of the Andes. New York: Charles Scribner's Sons, 1931.

MELLO E SOUZA, L. Inferno atlântico: demonologia e colonização. Séculos XVI-XVIII. São Paulo: Companhia das Letras, 1993.

MENA, C. de. La conquista del Perú, llamada la Nueva Castilla. In: SALAS, A. M. et al. Crónicas iniciales de la conquista del Perú. Buenos Aires: Plus Ultra, 1987. 
MENDIBURU, M. de. Dicionário histórico-biografico del Peru. Lima: Libreria e Imprenta Gil, 1935. t.I.

MENEGUS, M. La destrucción del señorío indígena y la formación de la república de indios en la Nueva España. In: BONILLA, H. El sistema colonial en la America española. Barcelona: Crítica, 1991.

MIGNOLO, W. Cartas, crónicas y relaciones del descubrimiento y la conquista. In: MADRIGAL, L. Í. (Coord.) Historia de la literatura hispanoamericana. Madrid: Cátedra, 1982.

MILLONES, L. Etnohistoriadores y etnohistoria andina: una tarea dificil, una disciplina heterodoxa. Socialismo y participación (Lima), n.14, jun. 1981.

. La población indigena durante el periodo colonial. In: CURATOLA, M.; SILVA-SANTISTEBAN, F. (Ed.) Historia y cultura del Perú. Lima: Universidad de Lima, Museo de La Nación, 1994.

MOLINA, C. de (El almagrista). Relación de muchas cosas acaescidas en el Perú. In: Crónicas peruanas de interés indígena. Madrid: Biblioteca de Autores Españoles, 1968. v.209.

MOLINA, C. de (El cuzqueño). Fábulas y ritos de los Incas. Buenos Aires: Editorial Futuro, 1959.

MOMMSEN, T. Historia de Roma. Buenos Aires: Joaquín Gil Editores, 1960.

MONTEIRO, H. M. O feudalismo: economia e sociedade. 2.ed. São Paulo: Ática, 1987. (Série Princípios, 38).

MONTESINOS, F. de. Memorias antiguas, historiales y políticas del Perú. Madrid: Imprenta de Manuel Ginesta, 1882.

MORE, T. Utopia. Lisboa: Publicações Europa-América, s. d.

MORI, J. de; ALONSO MALPARTIDA, H. La visitación de los pueblos indios. 1549.

MORRIS, C. L'étude archéologique de l'échange dans les Andes. Annales (Paris), année 33, n.5-6, sept./dec., p.936-47, 1978.

MOTOLINIA, T. Historia de los indios de Nueva España. Barcelona: Juan Gili, 1914.

MURRA, J.V. Temas de estructura social y economica en la etnohistoria y el antiguo folklore andino. Folklore Americano (Lima), año X, n.10, 1962.

El "control vertical" de un máximo de pisos ecológicos en la economía de las sociedades andinas. In: ZÚÑIGA, I. O. de. Visita 
de la provincia de León de Huánuco en 1562. Huánuco: Universidad Nacional Hermilio Valdizán, 1972. t.II.

Formaciones económicas y políticas del mundo andino. Lima: Instituto de Estudios Peruanos, 1975. (Historia Andina, 3).

La guerre et les rébellions dans l'expansion de l'État inka. Annales (Paris), année 33, n.5-6, sept./dec, p.927-35, 1978.

. La organización económica del estado inca. 3. ed. Mexico: Siglo XXI, 1983.

MURRA, J.V. (Ed.) Visita de los valles de Sonqo en los yunka de coca de La Paz: 1568-1570. Madrid: Instituto de Estudios Fiscales, 1991. MÚRUA, M. Historia General del Peru. Madrid: Historia 16, 1986.

O'BRIEN, P. A história da cultura de Michel Foucault. In: HUNT, L. A nova história cultural. São Paulo: Martins Fontes, 1992.

OCHOA, J. S. Los cronistas del Perú: contribución al estudio de las fuentes de la historia peruana. Cuzco: s. n., 1946.

O'GORMAN, E. A invenção da América. São Paulo: Editora UNESP, 1992.

ONDEGARDO, J. P. de. Informaciones acerca de la religión y gobierno de los incas. In: URTEAGA, H. H. Colección de libros y documentos referentes a la historia del Perú. Lima: Imprenta y Librería San Marti, 1916. t.III e IV.

El mundo de los incas. Madrid: Historia 16, 1990.

ORTIZ, R. Mundialização e cultura. 2.ed. São Paulo: Brasiliense, 1996. OSSIO ACUÑA, J. M. Expresiones simbolicas y sociales de los ayllus andinos: el caso de los ayllus de la comunidad de Cabana y del antiguo repartimiento de los Rucanas-Antamarca. In: CASTELLI, A. et al. Etnohistoria y antropologia andina. Lima: Centro de Proyección Cristiana, 1981.

OVIEDO, J. M. La edad del oro: crónicas y testimonios de la conquista del Peru. Barcelona: Tusquets Editores, 1986.

PACHACUTIYAMQUI SALCAMAYGUA, J. de S. C. Relación de antiguedades deste reyno del Pirú. Estudio Etnohistórico y Linguístico de Pierre Duviols y César Itier. Cuzco: Centro Estudios Regionales Andinos "Bartolomé de Las Casas", Instituto Francés de Estudios Andinos, 1993.

PASTOR, R. Sobre la articulación de las formaciones económico-sociales: comunidades de aldea y señorios en el norte de la Penín- 
sula Ibérica. In: BONASSIE, P. et al. Estructuras feudales y feudalismo en el mundo mediterráneo. Barcelona: Crítica, 1984.

PEASE, F. Del Tawantinsuyu a la Historia del Perú. Lima: Instituto de Estudios Peruanos, 1978.

Ayllu y parcialidad, reflexiones sobre el caso de Collaguas. In: CASTELLI, A. et al. Etnohistoria y antropología andina. Lima: Centro de Proyección Cristiana, 1981.

. Los incas. 2.ed. Lima: Pontificia Universidad Católica del Perú, 1992a. (Biblioteca "Lo que debo saber").

. Curacas, reciprocidad y riqueza. Lima: Pontificia Universidad Católica del Perú, 1992b.

La America de la conquista; punto de vista colonial. In: CURATOLA, M.; SILVA-SANTISTEBAN, F. (Ed.) Historia y cultura del Perú. Lima: Universidad de Lima, Museo de La Nación, 1994.

PIETSCHMANN, H. La Conquista de América: un bosquejo histórico. In: KOHUT, K. (Ed.) De conquistadores y conquistados: realidad, justificación, representación. Frankfurt: Vervuert, 1992.

PIZARRO, H. Carta de Hernando Pizarro a los oidores de la Audiencia de Santo Domingo. In: CANILLEROS, C. de. Tres testigos de la conquista del Perú. Buenos Aires: Espasa-Calpe, 1953.

PIZARRO, P. Relación del descubrimiento y conquista de los reinos del Perú. Lima: Pontificia Universidad Católica del Perú, 1978.

POLANYI, K. et al. Trade and markets in the early empires. Illinois: The Free Press Glencoe, 1957.

PORTUGAL, A. R. M. da C. M. Contribuciones de la etnohistoria para la comprension de la reciprocidad incaica y guarani. SequilaoRevista de Historia, Arte y Sociedad (Lima), año IV, n.8, p.69-84, 1995a.

O conceito de ayllu nas crônicas de interesse peruano do século XVI. São Leopoldo, 1995b. Dissertação (Mestrado) - Universidade do Vale do Rio dos Sinos.

Síntese analítica da concepção de ayllu em crônicas do século XVI. Estudos Leopoldenses, v.32, n.148, p.87-101, jul./ago. 1996. A caça às bruxas andinas no século XVII. In: ENCONTRO REGIONAL DA ANPUH, 8, 1998, Vassouras. Rio de Janeiro: Anpuh, 1998. CD-ROM. 
PRESCOTT, W. History of the conquest of Peru. London: Routledge, 1862.

PRODANOV, C. C. O mercantilismo e a América. São Paulo: Contexto, 1990. (Repensando a história).

QUEIJA, B. A. Tomás López Medel. Trayectoria de un clérigo-oidor ante el Nuevo Mundo. Guadalajara: Ediciones Pontón, 1993.

QUESADA, M. Á. L. La España de los reyes católicos. Madrid: Alianza Editorial, 1999.

R. PROVISION DANDO LICENCIA A LOS POBLADORES DEL PERU para que puedan comprar los esclavos que los caciques tuvieren, 1533. In: KONETZKE, R. Colección de Documentación de la Historia de la Formación Social de Hispanoamérica: 1493-1810. Madrid: Consejo Superior de Investigaciones Cientificas, 1953. v.I. RAMÍREZ, S. E. Social frontiers and the territorial base of curacazgos. In: MASUDA, S. et al. (Ed.) Andean ecology and civilization. Tokyo: University of Tokyo Press, 1985.

The world upside down: cross-cultural contact and conflict in sixteenth-century Peru. Stanford: Stanford University Press, 1996. RAMÍREZ, S. E. El concepto de "comunidad" en el siglo XVI. In: NOEJOVICH, C. H. América bajo los Austrias: economía, cultura y sociedad. Lima: Pontificia Universidad Católica del Perú, 2001.

RAYNAL, G.-T.-F. Histoire philosophique et politique des établissements et du commerce des européens dans les deux Indes. Paris: Libraires Associés, $1820.3 \mathrm{v}$.

RELACIÓN SÁMANO. In: XEREZ, F. de. Verdadera relación de la conquista del Perú. Madrid: Historia 16, 1985.

RICARDO, A. Vocabulario de la lengua general del Peru llamada Quichua y en la lengua española. Nuevamente enmendado y añadido de algunas cosas que faltavan por el Padre Maestro Fray Martinez ... Lima: Escobar Risco, 1951.

RISCO, G. E. Prólogo. In: RICARDO, A. Vocabulario de la lengua general del Peru llamada Quichua y en la lengua española. Nuevamente enmendado y añadido de algunas cosas que faltavan por el Padre Maestro Fray Martinez... Lima: Escobar Risco, 1951.

RIVA-AGÜERO Y OSMA, J. de la. La historia del Peru. Lima: Imprenta de Federico Barrionuevo, 1910.

. Los ayllus de los incas. Revista Histórica (Lima), v.11, 1937. 
ROBERTSON, W. The history of America. London: W. Strahan, T. Gadell, 1777. 2v.

ROMANO, R. Os conquistadores da América. Lisboa: Publicações Dom Quixote, 1972.

ROWE, J. H. Inca culture at the time of the Spanish conquest. In: STEWARD, J. H. Handbook of South American Indians. New York: Cooper Square, 1963. v.2.

RUBIO, D. de T. Arte de la lengua Qvichva... Lima: Francisco Lasso, s. d.

SAAVEDRA, B. El ayllu. Estudios sociologicos sobre América. Paris: Paul Ollendorf, 1913.

SÁENZ, S. D.-S. Un aporte a la reconstruccion del vocabulario agricola de la epoca incaica. Bonn: Estudios Americanistas de Bonn, 1985.

SAHAGÚN, B. de. Historia general de las cosas de Nueva España. México: Porrúa, 1985.

SAHLINS, M. Economía de la edad de piedra. Madrid: Akal, 1977. (Colección Manifiesto).

SALAS, A. M. et al. Crónicas iniciales de la conquista del Perú. Buenos Aires: Plus Ultra 1987.

SALOMON, F. Systèmes politiques verticaux aux marches de l'empire inca. Annales (Paris), année 33, n.5-6, sept./dec., p.967-89, 1978.

SALOMON, F. The Huarochiri manuscript. A testament of ancient and colonial Andean religion. Austin: University of Texas Press, 1991. SAN MIGUEL, G. D. de. Visita hecha en la provincia de Chucuito en el año 1567: documentos regionales para la etnología y etnohistoria andinas. Lima: Casa de la Cultura, 1964.

SANCHEZ, L. A. Isabel, a católica. Rio de Janeiro: O Cruzeiro, 1945. SANTILLÁN, H. de. Relación del origen, descendencia, política y gobierno de los Incas. In: Crónicas peruanas de interés indígena. Madrid: Biblioteca de Autores Españoles, 1968.

SANTISTEBAN TELLO, O. El ayllu y la tierra en el antiguo Peru. Mesa Redonda de Ciencias Prehistoricas y Antropologicas (Lima), v.1, n. 58a, 1969.

SANTO TOMÁS, D. de. Lexicon o vocabulário de la lengua general del Peru. Lima: Universidad Nacional Mayor de San Marcos, 1951. SANTOS, J. L. dos. O que é cultura. 9.ed. São Paulo: Brasiliense, 1983. (Primeiros passos, 110). 
SIDEKUM, A. História e utopia. Vale do Sinos (São Leopoldo), p.20-1, 11 jun. 1993.

SILVA, J. T. da. Descobrimentos e colonização. São Paulo: Ática, 1987. (Série Princípios, 114).

Descobrimentos e renascimento. 2.ed. São Paulo: Contexto, 1991. (Repensando a história).

SILVA-SANTISTEBAN, F. El significado de la conquista y el proceso de aculturacion hispano-andino. In: SOLANO, F. et al. Proceso histórico al conquistador. Madrid: Alianza Editorial, 1988.

Desarrollo tecnologico, ideologia y espacios de poder en el Peru antiguo. In: CURATOLA, M.; SILVA-SANTISTEBAN, F. (Ed.) Historia y cultura del Peru. Lima: Universidad de Lima, Museo de La Nación, 1994.

SILVERBLATT, I. Luna, sol y brujas: género y clases en los Andes prehispánicos y coloniales. Cuzco: Centro Estudios Regionales Andinos "Bartolomé de Las Casas", 1990. (Archivos de Historia Andina, 10).

SIMON, C. Acculturation and continuity: re-assessing the significance of Romanization in the hinterlands of Gloucester and Cirencester. In: WEBSTER, J.; COOPER, N. Roman Imperialism: post-colonial perspectives. Leicester: University of Leicester, 1996.

SOLANO, F. et al. Proceso histórico al conquistador. Madrid: Alianza Editorial, 1988.

SORIANO, W. E. El fundamento territorial del ayllu serrano. Siglos XV y XVI. In: CASTELLI, A. et al. Etnohistoria y antropología andina. Lima: Centro de Proyección Cristiana, 1981.

Los incas: economia, sociedad y Estado en la era del Tahuantinsuyu. 2.ed. Lima: Amaru, 1990.

SPALDING, K. Indian rural society in colonial Peru: the example of Huarochiri. Michigan, 1967. Thesis (Doctorate) - University of California.

STERN, S. Resistance, rebellion, and consciouness in the Andean peasant world, $18^{\text {th }}$ to $20^{\text {th }}$ centuries. London: The University of Wisconsin Press, 1987.

STEWARD, J. H. Handbook of South American Indians. New York: Cooper Square, 1963. v.2.

TAYLOR, G. Ritos y tradiciones de Huarochiri del siglo XVII. Lima: Instituto de Estudios Peruanos, Instituto Francés de Estudios Andinos, 1987. (Historia Andina, 12). 
TEMPLE, D. Estructura comunitaria y reciprocidad: del quid-pro-quo historico al ecomicidio. La Paz: Hisbol-Chitakolla, 1989.

TODOROV, T. A conquista da América: a questão do outro. São Paulo: Martins Fontes, 1983.

TOLEDO, F. de. Libro general de la visita del virrey don Francisco de Toledo, 1570-75. Revista Historica (Lima), v.VII, 1924. Informaciones acerca del señorio y gobierno de los incas. In: LEVILLER, R. Don Francisco de Toledo supremo organizador del Perú. Buenos Aires: CBCA, 1940a.

Ordenanzas que el señor visorey don Francisco de Toledo hizo para el buen gobierno de estos reinos del Perú. In: LEVILLER, R. Don Francisco de Toledo supremo organizador del Perú. Buenos Aires: CBCA, 1940b.

Tasa de la visita general de Francisco de Toledo. Int. y versión paleog. Noble David Cook. Lima: Universidad Nacional Mayor de San Marcos, 1975.

Disposiciones gubernativas para el Virreinato del Peru: 1569 -1574. Sevilla: Escuela de Estudios Hispano-Americanos, 1986.

TORD, L. E. El Virreinato. In: CURATOLA, M.; SILVA-SANTISTEBAN, F. (Ed.) Historia y cultura del Perú. Lima: Universidad de Lima, Museo de La Nación, 1994.

TRUjILLO, D. de. Crónica de Diego de Trujillo. In: XEREZ, F. de. Verdadera relación de la conquista del Perú. Madrid: Historia 16, 1985. TUDELA VALERA, F. Socialismo peruano: estudio sobre las comunidades indígenas. Lima: Imprenta La Industria, 1905.

TURNER, F. J. The frontier in American history. New York: s. n., 1958. UHLE, M. El aillu peruano. Lima: Boletín de la Sociedad Geografica, 1911.

URTEAGA, H. El imperio incaico, en el que se incluye la historia del ayllu y la familia de los incas. Lima: s. n., 1931.

VAINFAS, R. (Org.) América em tempo de conquista. Rio de Janeiro: Zahar, 1992.

. História das mentalidades e história cultural. In: CARDOSO, C. F.; VAINFAS, R. (Org.) Domínios da história: ensaios de teoria e metodologia. Rio de Janeiro: Campus, 1997.

VALCARCEL, L. E. Del ayllu al imperio. Lima: Editorial Garcilaso, 1925. 
Etnohistoria del Perú antiguo. Lima: Universidad Nacional Mayor de San Marcos, 1959.

. Historia del Peru antiguo. Lima: Editorial Universitaria. 1964. 6v. VALCÁRCEL MARTÍNEZ, S. Las crónicas como expresión y configuración de la mentalidad renacentista. Granada: Diputación Provincial de Granada, 1997.

VALERA, J. M. Organización de la sociedad en el Peru preincaico. Cuadernos Americanos, año XXXV, v.CGIV, n.1, ene./feb. 1976.

VILLASEÑOR, N. G. de. Perú: cronistas indios y mestizos en el siglo XVI. México: Sep, Setentas, 1975.

VISITA DE ACARI. Historia y Cultura (Lima), Museo Nacional de Historia, n.7, 1973.

WACHTEL, N. Sociedad e ideología: ensayos de historia y antropologia andina. Lima: Instituto de Estudios Peruanos, 1973. (Historia Andina, 1).

Los vencidos: los indios del Peru frente a la conquista española (1530-1570). Madrid: Alianza Editorial, 1976a.

. A aculturação. In: LE GOFF, J.; NORA, P. História: novos problemas. Rio de Janeiro: Francisco Alves, 1976b.

WEDIN, A. El concepto de lo incaico y las fuentes. Uppsala: Akademiförlaget, 1966.

XEREZ, F. de. Verdadera relación de la conquista del Perú. Madrid: Historia 16, 1985.

YUPANQUI, T. C. (Inca). Instrucción al licenciado don Lope García de Castro. Lima: Pontificia Universidad Católica del Perú, 1992.

ZÁRATE., A. de. Historia del descubrimiento y conquista del Perú. Buenos Aires: Universidad de Buenos Aires, 1965.

ZAVALA, S. La encomienda indiana. México: Porrúa, 1973.

ZUIDEMA, R. T. The ceque system of Cuzco. The social organization of the capital of the Inca. Leyden: Brill, 1964.

El ayllu peruano. In: CONGRESO INTERNACIONAL DE AMERICANISTAS, 26, 1966, España. Actas y memorias.

. La civilización inca en Cuzco. Mexico: Fondo de Cultura Económica, 1991.

ZÚÑIGA, I. O. de Visita de la provincia de León de Huánuco en 1562. Huánuco: Universidad Nacional Hermilio Valdizán, 1967, t.1. Visita de la provincia de León de Huánuco en 1562. Huánuco: Universidad Nacional Hermilio Valdizán, 1972. t.2. 



\section{ANEXOS}

\section{Anexo 1}

\section{Cronologia do século XVI}

1492 - Primeira viagem de Cristóvão Colombo às Antilhas.

1493 - Fundação de La Isabela, primeiro assentamento espanhol permanente na costa norte da ilha espanhola.

1493 - Bulas de Alexandre VI concedendo aos reis de Castela a exclusi-

vidade da evangelização nas Índias.

1494 - Tratado de Tordesilhas entre Castela e Portugal, delimitação de áreas de influência estabelecendo um meridiano-fronteira.

1499-1502 - Viagens andaluzas, exploração sistemática da costa sul-americana.

1502 - Coroação de Montezuma, soberano asteca.

1503 - Fundação da Casa de Contratação em Sevilha.

1508 - Bula Universalis Ecclesiae, que concede ao rei da Espanha o

Patronato Real da Igreja americana.

1511 - Sermão de Montesinos em Santo Domingo, denunciando a ex-

ploração dos índios. Criação da Jurisdição de Santo Domingo.

1512 - Leis de Burgos, que regulam as relações entre espanhóis e índios.

1513 - Descobrimento do Mar do Sul (Pacífico) por Vasco Núñez de Balboa. 
1515 - Bartolomé de Las Casas expõe pela primeira vez na corte de

Fernando, o Católico, sua defesa dos índios.

1519-1521 - Conquista do México por Hernán Cortez.

1522 - Pascual de Andagoya explora as costas do Pacífico e chega à

província do Peru.

1523 - Criação do Conselho das Índias.

1524-1525 - Primeira viagem de Francisco Pizarro ao Peru: chega ao

Rio San Juan, mas é impossível continuar mais adiante.

1526 - Contrato no Panamá entre Pizarro, Diego de Almagro e

Hernando de Luque para conquistar o Peru.

1527 - Segunda viagem de Pizarro pela costa.

1529 - Capitulación de Toledo entre a rainha e Pizarro.

1530 - Pizarro embarca em sua terceira e definitiva viagem.

1530 - Morte do inca Huayna Capac. Começa a guerra civil entre os

seguidores de Huascar e Atahualpa.

1532 - Começa a conquista do Peru por Francisco Pizarro.

1533 - Expedição a Pachacamac. Expedição e tomada de Cuzco. Pri-

meiras divisões de ouro e prata. Execução do inca Atahualpa. Coro-

ação de Tupac Hualpa como sucessor, que morre três meses depois.

Manco Inca é coroado em Cuzco.

1534 - Fundação espanhola de Cuzco.

1535 - Fundação de Lima.

1536 - Rebelião de Manco Inca em Cuzco. Juan Pizarro morre em

Sacsahuamán. A cidade de Lima foi sitiada, de onde saiu uma expe-

dição de auxílio a Cuzco, comandada por Alonso de Alvarado.

1537 - Almagro toma Cuzco e coroa Paullu Inca.

1538 - Batalha de Las Salinas: Hernando Pizarro vence Almagro e o

executa logo depois. Vitória de Manco Inca em Oncoy.

1539 - Fundação de Huamanga por Pizarro. Gonzalo Pizarro inicia sua

expedição em busca do País da Canela. Nasce o inca Garcilaso em Cuzco.

1541 - Em 26 de julho, Francisco Pizarro é assassinado em Lima. Almagro, el Moço, filho de Diego de Almagro, toma o poder.

Hernando Pizarro é encarcerado em Madri. Chega ao Peru como governador Cristóbal Vaca de Castro.

1541 - Hernando de Soto descobre o Mississipi.

1542 - Na batalha de Chupas, Vaca de Castro derrota Almagro, que é capturado e executado. Carlos V promulga as Nuevas Leyes (proí- 
bem a escravidão dos índios e declaram a extinção das encomiendas).

Criação do vice-reinado do Peru. Francisco de Orellana descobre o Rio Amazonas.

1543 - Criação do Consulado de Comércio de Sevilha. Nomeação do primeiro vice-rei do Peru.

1544 - Chega a Lima Blasco Núñez Vela, primeiro vice-rei do Peru.

Revolta de Gonzalo Pizarro, que entra em Lima e expulsa o vice-rei. Manco Inca é assassinado em Vitcos.

1545 - O rei nomeia Pedro de la Gasca pacificador do Peru.

1545-1546 - Descobertas minas de prata em Potosí e Zacatecas (Peru e México, respectivamente).

1546 - Batalha de Añaquito: Gonzalo Pizarro derrota e mata o vice-rei

Núñez Vela.

1547 - Na Batalha de Huarina, Gonzalo Pizarro derrota Diego de

Centeno. Regresso definitivo de Las Casas para a Espanha.

1548 - Pedro de la Gasca derrota Gonzalo Pizarro na batalha de

Jaquijahuana. La Gasca redistribui as encomiendas e negocia com os regentes do príncipe Sayri-Tupac.

1549 - Morte em Cuzco de Paullu Inca. Por cédula real, fica abolido o serviço pessoal dos índios no Peru.

1550 - La Gasca embarca para a Espanha. Antonio de Mendoza é vice-

-rei do Peru. Agrega-se a província de Tierra Firme ao vice-reinado do Peru.

1550 - Polêmica entre Bartolomé de Las Casas e Juan Ginés de

Sepúlveda sobre os índios americanos.

1551 - Primeiro Concílio Eclesiástico Limense. Criação da Universidade de San Marcos de Lima.

1552 - Morre o vice-rei Mendoza. Publicação da Brevíssima relación de la destrucción de las Indias, de Bartolomé de Las Casas.

1555 - Andrés Hurtado de Mendoza, marquês de Cañete, vice-rei do

Peru. Os encomenderos pedem a Carlos V um percentual de seus direitos. Bartolomé Medina introduz na Nova Espanha o método de amálgama para a metalurgia da prata, o que ocorre também no Peru, em 1573.

1556 - Chega ao Peru Hurtado de Mendoza. Abdicação de Carlos V e coroação de Felipe II.

1557 - O príncipe Sayri-Tupac deixa Vilcabamba depois de abandonar as negociações com os espanhóis. 
1558 - Morte de Carlos V.

1559 - Os curacas pedem a Felipe II o fim das encomiendas.

1560 - Morre em Lima o marquês de Cañete. Morte de Sayri-Tupac

em Vilcabamba. Frei Domingo de Santo Tomás publica a primeira gramática e vocabulário da língua quechua.

1561 - Início do governo do vice-rei Diego de Acevedo y Zúñiga, conde de Nieva.

1563 - Descoberta mina de mercúrio em Huancavelica, no Peru.

1564 - Morte violenta do vice-rei conde de Nieva, em uma aventura

amorosa. Governa Lope García de Castro, presidente da Audiência

de Lima. Descobrem-se os planos de rebelião de Titu Cusi.

1565 - Estabelecimento dos corregimentos de índios.

1566 - Titu Cusi firma o tratado de Acobamba com os espanhóis. Nova recopilação das Leis das Índias.

1567 - Motim de mestiços em Cuzco e Lima, comandado por García

de Castro. Segundo Concílio Eclesiástico Limense.

1568 - Junta Magma em Madri para estudar o governo do Peru.

1569 - Chega a Lima Francisco de Toledo, quinto vice-rei do Peru e um

dos mais importantes.

1570 - Visitas e informações de Toledo sobre a história dos incas. Apro-

va-se o trabalho forçado nas minas.

1571 - Morte de Titu Cusi, que é sucedido por Tupac Amaru. Toledo ordena a redução dos índios. Criação dos tribunais da Inquisição em Lima e no México.

1572 - Execução em Cuzco de Tupac Amaru, último soberano inca re-

conhecido pelos espanhóis.

1573 - Desterro dos nobres incas sobreviventes.

1574 - Sistema de mita para a exploração mineral estabelecida por Tole-

do em Potosí.

1575 - Toledo termina sua visita geral.

1579 - O pirata Drake assalta o porto de Callao.

1580 - União de Espanha e Portugal.

1581 - Martín Enríquez é vice-rei do Peru.

1582 - Terceiro Concílio Provincial de Lima.

1583 - Morre o vice-rei Martín Enríquez.

1584 - Antonio Ricardo instala a imprensa em Lima e publica Doctrina

cristiana y catecismo em quechua e aymara. 
1585 - Chega o vice-rei Fernando Torres y Portugal.

1586 - Terremoto em Lima e Callao.

1590 - García Hurtado de Mendoza é novo vice-rei do Peru.

1596 - Luis de Velasco é vice-rei do Peru.

1598 - Morre Felipe II e é sucedido por Felipe III.

1604 - Governo do vice-rei Gaspar de Acevedo y Zúñiga.

1608 - Chega a Lima o vice-rei Juan de Mendoza y Luna, marquês de

Montesclaros.

1609 - Aparecem em Lisboa os Comentários reales do inca Garcilaso.

1615 - Governo do vice-rei Francisco de Borja, príncipe de Esquilache.

Guaman Poma termina sua Nueva corónica.

1617 - Em Córdoba aparece a segunda parte dos Comentários reales. 1621 - Morre o rei Felipe III.

\section{Anexo 2}

\section{Biografia dos cronistas}

Para realizarmos as biografias dos cronistas utilizados em nossa pesquisa, consultamos as obras de Porras Barrenechea, Mito, tradicción e historia del Peru (1973) e Los cronistas del Peru (1986), em que o autor vai construindo a história dos incas por meio das crônicas e faz uma catalogação destas, separando os cronistas por status social e época em que escreveram. Também analisamos a obra de Jose Miguel de Oviedo (1986), La edad del oro: crónicas y testimonios de la conquista del Peru, em que aparecem várias citações de crônicas que abordam a história da conquista. Ao final, o autor apresenta detalhadamente a biografia de cada cronista. O autor Julián Santisteban Ochoa (1946), em Los cronistas del Perú: contribución al estudio de las fuentes de la historia peruana, cataloga todos os cronistas de acordo com o conteúdo de suas crônicas. Revisamos ainda a obra Cronistas del Peru antiguo de Francisco Carrillo Espejo (1989), em que aparecem detalhadas as biografias de Juan de Betanzo, Pedro Cieza de León, Polo de Ondegardo, Pedro Sarmiento de Gamboa, o Jesuita Anónimo, Cristóbal de Molina, Fernando de Montesinos e Martín 
de Múrua. Salas et al. (1987) fazem um trabalho semelhante em Crónicas iniciales de la conquista del Perú, porém tratam apenas de forma genérica os demais cronistas e se concentram na análise e apresentação das crônicas de Cristóbal de Mena, Francisco de Xerez, Miguel de Estete e da Relación de los primeros descubrimientos de Francisco Pizarro y Xerez.

Agustín de Zárate (1514-15?)

Chegou ao Peru em 1543 com a incumbência de tomar conta dos oficiais da Hacienda Real e escreveu a Historia del descubrimiento y conquista del Perú, publicada em Amberes, em 1555. Sua crônica é uma das mais importantes para a história do Peru, principalmente no que concerne às guerras civis entre almagristas e pizarristas. Há indícios de que viveu na Andaluzia, em 1578.

Bartolomé de Las Casas (1474-1566)

Sem dúvida, a figura mais polêmica e apaixonada do debate intelectual sobre a questão do indígena explorado e escravizado pela conquista da América. Estudou filosofia e direito em Salamanca e foi para a Española em 1502, com a expedição de Nicolas de Ovando. Trabalhou nos repartimientos que obteve do seu pai nesse lugar e teve numerosos indígenas ao seu serviço. Porém, estimulado pelos sermões do dominicano frei Pedro de Córdoba, optou pela vida religiosa (1510). Sua atitude indolente perante os indígenas não mudou de imediato: em Cuba foi acusado de escravizar os índios que empregava em suas terras. No entanto, em 1515 sofreu uma crise religiosa e moral: compreende a injustiça essencial do trato aos índios, renuncia aos seus bens, cede suas terras e se consagra à defesa dos naturais, o que lhe dará o nome de Apóstolo de las Indias. De volta à Espanha entre 1516 e 1520, advogou perante o rei para obter ordenanças mais justas. Em 1523 ingressou na ordem dos dominicanos. Em seu frenético trabalho de defesa dos indígenas, Las Casas foi ganhando inimigos que o atacaram e caluniaram. Em parte, Las Casas provocou essas violentas reações contra ele, porque, na paixão de sua causa, chegou a considerar-se uma figura pre- 
destinada e caiu na intransigência e na violência. Obteve um triunfo pessoal quando Carlos V promulgou as Nuevas Leyes (1542), porém não aceitou a responsabilidade de ser bispo de Cuzco e nunca esteve no Peru, onde sua presença podia ser decisiva. Aceitou em troca um mandato de sua ordem para o cargo do bispado de Chiapas (1544). Regressou à Espanha em 1547 e renunciou ao seu cargo em 1550. Morreu em Madri. Sua obra histórica é extensa, nela se destacam Breísima relación de la destucrición de las Indias (1552) e Historia de las Indias (1576). Apologética historia sumaria é escrita em 1550 e publicada em Madri, em 1909. Escreveu algumas outras obras em latim.

Bernabé Cobo (1580-1657)

Nasceu em Lopera, Jaén. Fascinado pela lenda do El Dourado, viajou em 1595 para as Índias, onde viveria 61 anos. Passou os primeiros na América Central, onde estudou toda a realidade natural e cultural americana. Chegou ao Peru em 1599. Cursou humanidades no Real Colegio de San Martín e logo passou ao noviciado dos jesuítas e ao Real Colegio de San Pablo. Em Cuzco, continuou os estudos religiosos entre 1609 e 1613 e recebeu as ordens. Esteve no colégio jesuíta de Juli, perto do Lago Titicaca. Visitou o tribunal de Charcas, viajou incansavelmente por todo o Peru e em 1629 obteve autorização para ir ao México, onde passou vinte anos e terminou ali a sua monumental obra. Em meados de 1642, estava de volta a Lima, cidade onde morou. La historia del Nuevo Mundo é um trabalho enciclopédico que consta de três partes e 43 livros; somente se conhece a primeira parte, impressa em Sevilha entre 1890 e 1893. Sua Historia de la fundación de Lima (1882) foi, segundo o próprio Cobo, extraída da segunda parte da obra anterior.

Blas Valera (1551-1597)

Valera era um cronista mestiço, conhecido como o Jesuita Anónimo. Sua obra foi difundida pelas frequentes e extensas citações que Garsilaso de la Vega intercalou em seus Comentários reales. Nasceu em Chachapoyas, na região amazônica. Estudou no colégio 
de San Pablo e, em 1571, foi enviado a Cuzco, por causa de seus conhecimentos de quechua, para trabalhar nas missões. Recebeu também o encargo de recopilar notícias sobre a vida no tempo do império. Esteve no III Concílio Limense (1583). Para cuidar da impressão de sua Historia de los incas, viajou para Cadiz. Em razão do saque desta cidade promovido pelos ingleses (1596), só se conservaram os fragmentos que ele mesmo entregou a Garsilaso em 1600. Seu Vocabulário quéchua também se perdeu. É atribuída a Valera a crônica Las costumbres antiguas del Peru, publicada por M. Jiménez de la Espada em 1879.

\section{Cristóbal de Mena (?)}

Possivelmente nasceu em Medina del Campo. Viajou pelas Índias até 1513. Esteve na conquista da Nicarágua como capitão de Pedrarias Dávila (1522). Em 1531, embarcou com Pizarro para a conquista do Peru. Foi seu lugar-tenente até a ilha de Puná e oficial de justiça em Túmbez e San Miguel de Piura. Foi posto de lado na expedição a Cajamarca e decidiu voltar à Espanha. Sem utilizar o próprio nome, publicou La conquista del Perú llamada la Nueva Castilla (1534). Até Raúl Porras identificá-lo, Mena foi conhecido como "El anónimo sevillano de 1534".

Cristóbal de Molina, El Chileno (1494-1580)

Nasceu em Legamiel, perto de Huete. Antes de 1532, encontrava-se em Santo Domingo e nesse mesmo ano no Panamá. Dois anos depois, partiu para o Peru, na frustrada expedição de Gaspar de Spinoza, e chegou com este ao Rio San Juan, de onde regressou ao Panamá. Em 1535, encontrava-se em Lima. Acompanhou Almagro na conquista do Chile. De volta a Lima (1539), foi vigário da paróquia de Sagrario. Regressou uma vez mais ao Chile (1556) com o governador García Hurtado de Mendoza. Viveu também em Cuyo e Mendoza. Morreu no Chile. A sua Relación de la conquista e población del Perú data de 1552: foi publicada em francês em 1842 e em espanhol, em Santiago do Chile, em 1873. 
Cristóbal de Molina, El Cuzqueño (1529?-1585)

Nasceu em Baeza. Deve ter viajado pela América na segunda metade do século XVI. Viveu e morreu em Cuzco, donde provém o seu apelido com que ele se distingue de seu homônimo, cronista como ele. Era clérigo e com bom conhecimento de quechua, foi doutrinador de índios. O vice-rei Toledo o nomeou visitador naquela cidade em 1572 e 1575. Deu assistência ao inca Tupac Amaru antes de este ser executado (1572). A sua Relación de las fábulas y ritos de los Incas, escrita em 1575, foi publicada primeiro em inglês por sir Clements R. Markham em 1873 e em espanhol, em Santiago do Chile, em 1913.

Diego de Trujillo (1505-1576)

Nasceu em Trujillo de Extremadura. Em 1530, foi para as Índias com Francisco Pizarro e esteve com ele nas ações em Cajamarca, Cuzco e Jauja. Em 1534, viajou para a Espanha, mas, ao esgotar-se sua fortuna, voltou ao Peru (1543). Em sua casa em Cuzco, ofereceu refúgio aos filhos de Atahualpa. Durante as guerras civis, esteve ao lado dos defensores do rei. Em pagamento a essa fidelidade, Toledo lhe outorgou uma encomienda. Morreu em Cuzco. Escreveu Relación del descubrimiento del Reyno del Perú, que Raúl Porras publicou pela primeira vez em 1948.

Felipe Guaman Poma de Ayala (1525?-1615?)

Foi o mais notável de todos os cronistas e, em muitos sentidos, o mais original na recuperação e interpretação do mundo indígena. Pouco se sabe sobre Ayala. A data de seu nascimento oscila entre 1526 e 1545. Sua terra natal era San Cristóban de Suntuto. O pai era senhor de vários povoados em Chinchaysuyo, e a mãe, Curi Ocllo, filha do inca Tupac Yupanqui. O sobrenome de Ayala ele tomou do capitão Luis Avalos de Ayala, a quem seu pai salvou numa batalha de Huarina (1547). Foi criado num ambiente que mantinha vivas as tradições indígenas e a amarga lembrança dos maus-tratos recebidos não apenas dos espanhóis, mas também da dinastia imperial de Cuzco, pois os Poma de Ayala pertenciam à casta de yarovilcas, cujos herdeiros foram deslocados à força. Isso não o im- 
pediu de ser auxiliar de Cristóbal de Albornoz na extirpação do movimento milenarista indígena chamado Taqui Ongoy (1565-1570), de acompanhá-lo em suas visitas e talvez de ser intérprete no Concílio Limense de 1583. Em 1595, foi auxiliar na visita de Gabriel Solano de Figueroa a Huamanga e possivelmente curaca e tenente-governador. Há indícios de que, depois de ser preso por Antonio Monroy, começou a viajar por todo o país para conhecer de primeira mão toda a situação geral dos índios e promover para eles o que chamava o bom governo. Essa peregrinação durou aproximadamente vinte anos, que lhe deram uma visão geral da vida colonial, de seus males e seus remédios. Ao voltar para sua terra, pobre e já muito ancião, foi acusado de ter usado cargos e nomes falsos pelo corregedor de Huamanga, Pedro López de Toledo (1600). Fugiu para Lima, onde deu notícias ao vice-rei Velasco. O cronista tratou de viajar para a Espanha para expor seu caso e o dos nativos. Morreu em Lima sem chegar a fazê-lo. Deixou escrita sua vasta Nueva corónica y buen gobierno, que é exemplo único do gênero: como seu autor tinha somente um conhecimento rudimentar da língua espanhola e temia não ser compreendido, incluiu aproximadamente quatrocentos desenhos seus que ilustram sua denúncia e constituem um documento gráfico de importância capital. A crônica permaneceu desconhecida até o começo do século XX: em 1908, foi descoberta por Richard Pietschmann na Biblioteca Real de Copenhague e publicada em edição resumida por Paul Rivet em 1937.

\section{Fernando de Montesinos (?-1664)}

Nasceu em Osuna. Chegou ao Peru com o vice-rei, conde de Chinchón (1628), e, como presbiteriano, cumpriu várias funções: secretário do bispo de Trujillo, reitor do colégio desta cidade, curador em Potosí, visitador em Arica, capelão em Lima, juiz eclesiástico em Cajamarca etc. Animado por uma paixão aventureira e por sua voraz curiosidade, organizou uma expedição pela selva (1637). Regressou à Espanha e recebeu um curato perto de Sevilha, onde morreu. Fora as obras sobre a exploração dos metais, escreveu as crônicas Memorias antiguas, historiales y políticas del Perú e Anales del Perú(1598-1642), 
publicadas em 1870 e 1906, respectivamente. Historia del Paititi ainda continua inédita.

Francisco de Ávila (1573-1647)

Nasceu em Cuzco onde foi criado pelos pais adotivos, pois os naturais o abandonaram. Em 1592, mudou-se para Lima para estudar na Universidad Nacional Mayor de San Marcos. Ordenou-se em 1596 e um ano mais tarde se tornou curador de San Damián na província de Huarochiri, pertencente à arquidiocese de Lima; em 1598 foi nomeado vigário e juiz eclesiástico da mesma jurisdição. Durante sua gestão como cura de índios, foi acusado de abusos e de outras faltas graves, o que o levou a ser julgado e encarcerado em Lima. Logo, após um longo processo, foi absolvido e reabilitado em sua política pessoal de extirpação de idolatrias. Seu Tratado y relación de los errores, falsos dioses y otras superticiones y ritos... é de 1608. Em 1610 , foi nomeado juiz visitador e regressou a San Damián, onde realizou uma intensa atividade religiosa. Em 1611, escreveu a sua Relación de antiguedades deste reyno del Pirú. Passou catorze anos em Chuquisaca e regressou a Lima em 1632, dedicando-se então a escrever uma série de obras. Em 1641, foi rechaçado o seu pedido de ingresso na Companhia de Jesus, aparentemente por causa de sua condição de mestiço. No ano seguinte de sua morte, apareceram, em dois volumes, seus sermões em língua quechua, nos quais havia trabalhado em seus últimos anos. A narração quechua, recolhida por ele e traduzida por José María Arguedas para o espanhol sob o título de Dioses y hombres de Huarochirí, data provavelmente de 1598.

\section{Francisco de Toledo (1515-1584)}

Nasceu em Oropesa (Toledo), em uma grande família da nobreza espanhola. Aos 19 anos, colocou-se a serviço de Carlos V como soldado em diferentes campanhas e foi diplomata em missões na Europa e África. Felipe II o nomeou vice-rei do Peru em 1568. Entre 1570 e 1575, iniciou minuciosa e prolongada visita general do Peru com o objetivo de planejar e descrever o lugar das novas reduções. Dessa visita, originaram-se Informaciones e Ordenanzas de To- 
ledo, material muito importante para conhecer a cultura inca e a instalação de um novo sistema colonial. O governo de Toledo durou doze anos, e este morreu pouco depois de regressar à Espanha em 1584 .

Francisco de Xerez (1497-?)

Xerez nasceu em Sevilha. Aos 17 anos, foi para as Índias como parte da armada de Pedrarias Dávila. Viveu aproximadamente dez anos em Castilla Del Oro, ao lado de alguns dos futuros descobridores do Peru. Esteve entre os que realizaram a primeira viagem com Pizarro em 1524, encarregado da função de escrivão. Entretanto, não figurou entre os treze homens que ficaram na Ilha Del Gallo e descobriram o Peru. Regressou ao Panamá empobrecido. Em 1528, esteve outra vez em Castilla Del Oro como escrivão do governador Pedro de los Rios. Em 1530, voltou a tomar parte das hostes de Pizarro. Serviu-lhe como secretário na viagem definitiva e viveu diretamente a campanha que culminou em Cajamarca. Em 1534, voltou a Sevilha, e, no ano seguinte, divulgou-se a sua Verdadera relación de la conquista del Perú..., escrita em 1533. Também lhe pertence a chamada Relación Sámano - Xerez, de 1528, breve relato das primeiras viagens de Pizarro ao Peru, que fora remetido por Juan de Sámano, secretário de Carlos V, a um príncipe da casa de Áustria. Na Espanha, Xerez se dedicou ao comércio com Tierra Firme e aumentou a considerável fortuna obtida no Peru. Perdida esta, em 1554 solicitou retorno às Índias com a mulher e quatro filhos. Obteve vários corregimentos no Peru, porém não se sabe ao certo se chegou a exercer o cargo neles, pois não existem dados dos últimos anos de sua vida.

\section{Francisco López de Gómara (1511-1560?)}

Entre os cronistas das Índias, Gómara é um dos mais elegantes e ilustrados. Não se sabe ao certo onde nasceu, se em Soria ou Sevilha. Beneficiado com uma sólida formação humanística, conheceu bem os autores clássicos e cultivou o latim. Tornou-se clérigo em 1530 e partiu de imediato para a Itália onde enriqueceu seu conhecimento 
da cultura antiga. Quando regressou à Espanha, tornou-se capelão no serviço de Hernán Cortez. Acompanhou-o na expedição de Argel e esteve ao seu lado até a morte de Cortez (1547). Sua amizade com ele explica a idealização e lisonja do conquistador do México que se aprecia em sua Historia general de las Indias, escrita provavelmente em Valladolid e publicada em Zaragoza em 1552. Para refutá-lo, Bernald Díaz Castillo escreveu a sua Verdadera historia de la conquista de la Nueva España (1632). Pela mesma devoção a Cortez, Gómara rebaixou também a figura de Pizarro e a importância do Peru, onde nunca esteve.

Francisco Falcon (?)

Redigiu a Representacion sobre los daños y molestias que se hacen a los indios dirigida à autoridade eclesiástica representada no Concílio Limense de 1583. Defendeu os índios diante dos agravos praticados pelos espanhóis com o objetivo de alertar para a necessidade de realizar um bom processo de evangelização junto aos índios.

Garcilaso de la Vega (1539-1616)

Não apenas é o maior cronista do Peru, mas também o primeiro grande escritor americano e um dos espíritos mais refinados e elegantes do século de ouro. Nasceu em Cuzco, filho bastardo de um conquistador espanhol e de uma princesa inca; era, assim, um mestiço nobre por ambas as vertentes do seu sangue. Essa dupla condição - filho natural, porém com antecedentes ilustres, índio e espanhol, americano e europeu - tornou La Vega e sua obra um dos casos mais interessantes das letras coloniais, um vivo e trágico exemplo do que foi a conquista. Quando menino, educou-se em Cuzco com outros filhos mestiços dos conquistadores Francisco y Gonzalo Pizarro, o que lhe permitiu ser testemunha direta de alguns acontecimentos-chave da época. A educação do inca (que em sua infância se chamava Gómez Soárez de Figueroa) também foi dupla: por um lado, os mestres que lhe deu seu pai lhe ensinaram gramática e latim e o adestraram na arte equestre; por outro, sua mãe, Isabel Chimpu Ocllo, e seus parentes maternos mantinham viva em sua memória a 
lembrança da dinastia imperial cuzquenha, a que pertencia, e da raça vencida. As confusões políticas de seu pai, o capitão Garsilaso de la Vega, trouxeram dias de inquietude e penúria na sua meninice e, logo, dificuldades para reclamar sua fortuna na Espanha. Já jovem, viajou pela zona andina e absorveu o impacto da paisagem. Entretanto, seu pai se havia casado com uma dama espanhola, dona Luisa Martel, com o propósito de conservar a sua comenda. A mãe de Garsilaso, abandonada, se casou com um escudeiro; o inca passou a viver com o pai e a madrasta, o que deve ter deixado nele uma amarga marca emocional. O pai morreu em 1559; em seu testamento deixou ao inca uma quantidade de dinheiro para que fosse estudar na Espanha. Garsilaso realiza essa viagem em 1560 e não regressa mais ao Peru. Na Espanha se dedica à carreira das armas: ganha o título de capitão de Sua Majestade, combate na guerra contra os mouros nas Alpujarras até a campanha na Itália, onde aprende o toscano e descobre León, El Hebreo, filósofo neoplatônico cuja obra logo traduziria. Consagra-se à vida literária e religiosa. Frequenta os círculos humanistas em Sevilha, Montilha e Córdoba. São esses anos de estudo, recolhimento espiritual e preparação de suas obras maiores; na realidade, a vida literária de Garsilaso começa depois dos seus cinquenta anos e talvez isso explique a impressão de serenidade, equilíbrio e nostalgia que produzem no leitor. Sua tradução dos Diálogos de amor de León, El Hebreo, foi publicada em Madri, em 1590. É autor de La florida del inca (1605), Comentarios reales (1609) e Historia general del Perú, que é a segunda parte de Comentarios.

\section{Girolamo Benzoni (1519-157?)}

Nasceu em Milão, foi para a América em 1541 e regressou à Itália em 1556. Há poucos dados sobre sua vida, apenas se sabe que esteve em Tierra Firme, depois nas Ilhas do Caribe, em Cartagena e no Panamá. Chegou a Guayaquil entre 1547 e 1550. Retornou ao Panamá, depois foi para Nicarágua, Guatemala e Cuba, e finalmente retornou à sua pátria. Publicou sua Historia del Nuevo Mundo em 1565. 
Gonzalo Fernández de Oviedo (1478-1557)

Foi um dos maiores cronistas das Índias. Nasceu em Madri, foi pajem do príncipe Juan e mandatário e tenente do rei Fernando. Era um fidalgo letrado e humanista que passou pelas Índias com Pedrarias Dávila em 1514, como funcionário do rei. Na América foi escrivão de minas, fundidor de metais e marcador de índios escravos. Viveu deslocando-se continuamente entre um e outro continente, ao longo de mais de quatro anos. Esteve principalmente no Caribe, em Darién e na Nicarágua. Alternou também desordens e amizades com Pedrarias, que chegou a fazê-lo tenente-governador de Darién. Em 1525, apresentou a Carlos V o seu Sumario de la natural historia de las Indias, primeira enciclopédia da natureza e geografia da América. Publicou a primeira parte de sua Historia general de las Indias (vinte livros) em 1535, em Sevilha. Desde 1532 era, por ordem do rei, cronista das Índias, e, em 1535, tonou-se alcaide da Fortaleza de Santo Domingo. Em suas cartas ao rei (1537), defendeu a causa de Almagro em sua disputa com Pizarro. Morreu em Valladolid, deixando inédita a parte de sua crônica relativa ao Peru, em que trabalhou durante seus últimos anos. É autor de outras variadas obras de caráter histórico, genealógico e militar.

\section{Hernando Pizarro (1502-1578)}

Quando seu irmão Francisco Pizarro se encontrava na Espanha, em 1529, Hernando decidiu ir às Índias como simples soldado. Teve papel destacado na expedição conquistadora, na captura de Atahualpa e na tomada do Templo de Pachacamac. Levou para a Espanha (1533) o quinto que pertencia ao rei pelo resgate de Atahualpa. De volta ao Peru, esteve entre os defensores de Cuzco, atacados pelo rebelde Manco Inca. Inimigo de Almagro pela possessão da cidade, derrotou-o na batalha de Las Salinas (1538) e determinou a sua execução. Como consequência desses atos, Hernando permaneceu preso durante 21 anos, na Espanha. Por matrimônio com sua sobrinha, filha de Francisco Pizarro, e pelas encomiendas e minas que esta lhe reservou, converteu-se em um 
dos homens mais ricos da Espanha. Morreu quase cego em Medina Del Campo. A Carta de Hernando Pizarro a los oidores de la Audiencia de Santo Domingo foi concluída em 23 de novembro de 1533 e parece ter sido copiada nessa cidade por Fernández de Oviedo, que a publicou em sua Historia general e natural de las Indias.

Hernando Santillán (?-1575)

Santillán era andaluz de origem ilustre. Chegou ao Peru em 1548 e, em 1550, foi nomeado ouvidor da Audiência de Lima, organismo que se encarregou do governo do Peru em 1552, após a morte do vice-rei Dom Antonio de Mendoza. Foi ferido na batalha de Púcara, em que os ouvidores derrotaram o rebelde Hernandez Girón. Foi conselheiro de Dom García Hurtado de Mendoza, filho do falecido vice-rei, quando aquele foi nomeado governador do Chile. Após algumas discrepâncias com ele, regressou a Lima em 1559, foi submetido a juízo de residência e condenado a pagar uma multa e a sofrer desterro. Viajou para a Espanha em 1562 e, ao demonstrar sua tenacidade como político, regressou à América como presidente da recém-criada Audiência de Quito (1563). É novamente submetido a juízo de residência em 1569: condenado a multa e desterro, regressou uma vez mais à Espanha em 1570. Ingressou na vida religiosa e foi nomeado bispo de Charcas em 1572, porém não tomou posse do cargo. Sua obra, conhecida como Relación del origen, descendencia, política y gobierno de los Incas, escrita para o rei, data de 1563 e foi publicada em Madri, em 1879.

José de Acosta (1540-1600)

Nasceu em Medina Del Campo e ingressou muito jovem na ordem dos jesuítas. Foi catedrático de teologia em Ocanã e fez-se famoso por seus dotes de oratória. Chegou ao Peru em 1572, com o terceiro contingente de jesuítas que chegou ao país. De espírito curioso e inclinado à observação da natureza e da condição social do indígena, viajou pela zona andina em uma expedição pelo vice-rei Toledo. Foi reitor do Colégio de San Pablo em Lima (1575), provincial 
da sua ordem (1576) e catedrático de teologia na Universidade de San Marcos (1580). Com a ajuda do padre Blas Valera e outros, publicou catecismos em quechua e aymara para a instrução dos índios. A doctrina cristiana y catecismo, que publicou em 1584, é o primeiro livro impresso no Peru. Em 1585, abandonou o país, passou três anos no México e voltou à Espanha em 1588. Participou ativamente nas guerras internas que agitaram a Companhia. Passou seus últimos anos ensinando em Valladolid. Morreu sendo reitor do colégio jesuíta de Salamanca. Sua Historia natural y moral de las Indias (1590)é uma obra fundamental para conhecer a geografia e o mundo natural do Peru. Entre suas obras em latim, destaca-se De procuranda indorum salute (1588).

Juan de Betanzos (1510-1576)

Nasceu na Galícia. Ignora-se a data exata de sua chegada ao Peru, onde se casou com a filha do inca Huaina Capac. Seu conhecimento de quechua lhe permitiu ser intérprete oficial nas hostes de Pizarro e na Audiência de Lima. Nas guerras civis, participou ao lado de Gonzalo Pizarro, mas depois esteve no exército do pacificador La Gasca, que lhe permitiu obter uma encomienda. Esteve entre os homens enviados pelo vice-rei para negociar com Sayri-Tupac (1557). Residiu em Cuzco e Lima. Trabalhou em livros de doutrina cristã em quechua e em dois vocabulários. Sua crônica Suma y narración de los Incas foi escrita em 1551 e publicada pela primeira vez em Madri, em 1880.

\section{Juan de Matienzo (1520-1579)}

Nasceu em Valladolid, em 1520. De uma família de juristas, também estudou direito em sua cidade. Chegou ao Peru em 1561, onde ficou como ouvidor da Audiência de Charcas durante treze anos. Depois disso, escreveu sua obra Gobierno del Perú, em que planejou o reagrupamento de índios em reduções, levado a cabo por Francisco de Toledo, grande amigo a quem assessorava. Morreu em 1579, em Charcas. 
Juan Polo de Ondegardo (?-1575)

Nasceu em Valladolid. Chegou ao Peru com o vice-rei Blasco Núñez Vela (1544), com a missão de velar, como jurista, pelos interesses de Hernando Pizarro. Tomou o bando da Audiência de Lima, quando esta entrou em conflito com o vice-rei, e depois o de Gonzalo Pizarro. Carbajal desconfiou e o encarcerou primeiro em Cuzco e, depois, em Lima, de onde o cronista conseguiu fugir. Fora suas virtudes como letrado, Polo de Ondegardo teve a capacidade física para participar ativamente na mais dura das guerras civis: era um homem forte, capaz de cruzar rios bravos a nado e de disparar com maestria um arcabuz. Em recompensa por seus esforçados serviços nas campanhas, La Gasca o encarregou da tarefa de submeter os rebeldes de Charcas. Assumiu também a responsabilidade de organizar as expedições para La Plata e Tucumán. Regulamentou a exploração do mineral nas minas Potosí, obteve uma rica encomienda em Cochabamba e combateu a rebelião de Hernandes Girón. Foi nomeado regedor de Cuzco (1558-1561) onde fez um pouco de arqueologia e se interessou vivamente pela cultura indígena. Teve atuação destacada ao lado dos vice-reis conde de Nieva e Toledo. Deixou uma grande fortuna ao morrer em La Plata. Na confusa e extensa bibliografia do autor, podem-se mencionar: Tratado y averiguación sobre los errores y superticiones de los indios (1559), Instrucción contra las ceremonias y ritos que usan los indios conforme ao tiempo de su gentilidad (1567) e Informaciones acerca de la religión y gobierno de los Incas (1916) - esta edição contém o primeiro título mencionado e a Relación de los fundamentos acerca del notable daño que resulta de no guardara los indios sus fueros, que data de 1571.

\section{Juan Santa Cruz Pachacuti Yamqui Salcamaygua (?)}

Os dados biográficos sobre Salcamaygua são escassos e vagos. Sabe-se que nasceu perto de Canchis, em Cuzco, e que sua linhagem era de collaguas. Sua Relación de antiguedades deste reyno del Perú, escrita em 1615, foi publicada em Madri, em 1879. Sua importância reside em ser quase uma transcrição dos mesmos cantares históricos quechuas das dinastias incaicas. 
Martín Múrua (?)

Não se sabe ao certo onde Múrua nasceu, se em Guernica ou Azpeitia. Esteve em Cuzco em 1560, a cargo desta província da ordem mercedaria a que pertencia. Aprendeu quechua e aymara em seu trabalho de evangelizador. Em Ayamares, teve uma disputa com o cronista Guaman Poma de Ayala, que o acusou de curadoria abusiva e dissoluta e o retratou como tal em um de seus desenhos. Em 1595, foi procurador do convento de sua ordem em Cuzco, residiu em Arequipa (1600) e, outra vez, na cidade imperial, tornou-se comendador de seu convento (1608). Escreveu sua obra entre as duas cidades e concluiu-a em 1611. Viajou para a Espanha com desejo de imprimi-la. Obteve a autorização em 1616, porém não conseguiu publicá-la. Viajou por La Paz, Chuquisaca, Potosí e Buenos Aires, entre 1612 e 1614. Sua crônica foi publicada com distintos títulos e substanciais variantes textuais: Historia de los incas reales del Peru em 1922-1925, em Lima; Historia del origen e genealogía real de los reyes incas del Peru, em 1946, em Madri; e Las orígenes de los incas em 1946, em Lima. Segundo Raúl Porras, o trabalho de Múrua é uma das crônicas mais pitorescas, imaginativas e insinuantes escritas sobre o Peru.

Miguel Cabello Balboa (1535-1608)

Nasceu em Archidona. Estimulado pelo desejo de catequizar os indígenas, ingressou na carreira religiosa em Málaga. Já ordenado sacerdote agostiniano, chegou às Índias em 1566. Esteve em Bogotá e Quito: no Peru obteve a cúria de San Juan no Vale de Ica (1580), e em Camatá, o corregimento de Larecaja (1594). Morreu na sede desta última curadoria. Sua principal obra é a curiosa Miscelánea antártica, escrita entre 1576 e 1586.

\section{Miguel de Estete (1507-1550?)}

Nasceu em Santo Domingo de la Calzada. Esteve na conquista da Nicarágua quando tinha 25 anos. Acompanhou Pizarro em sua primeira exploração da terra peruana, desde Piura até Cajamarca. Esteve na escolta de Hernando de Soto que visitou a tenda que o 
Inca tinha nos arredores dessa cidade e com os homens de Hernando Pizarro chegou até Pachacamac, cujo famoso templo descreveria. Percorreu, outra vez com Pizarro, Jauja e Cuzco, porém parece que não esteve na fundação desta cidade. Sabe-se que regressou logo à Espanha, porém seus rastros confundem-se com os de outro soldado com o mesmo nome. Morreu em 1550. Sua Relación del viaje que hizo el señor capitán Hernando Pizarro por mandato del señor gobernador, su hermano, desde el pueblo de Caxamalca a parama (sic), y de alli a Jauja foi incluído por Francisco de Xerez em sua Verdadera relación... (1534). Sua crônica El descubrimiento y conquista del Perú foi publicada em 1819.

Pablo José de Arriaga (1564-1622)

Nasceu em Vergara Viscaya e foi sacerdote jesuíta da Ordem em Ocaña y Vergara. Chegou ao Peru em 1585. Foi professor de retórica no Real Colégio de San Martin e tornou-se reitor em 1588. Como procurador da Companhia, voltou à Espanha em 1601. Regressou ao Peru e realizou um vasto trabalho missioneiro, na campanha ordenada pelo arcebispo Lobo Guerrero, com fim de extirpar as idolatrias. Sua principal obra é Extirpación de la idolatría en el Pirú.

\section{Pedro Cieza de León (1522-1554)}

Foi um dos cronistas fundamentais da conquista do Peru. Nasceu em Lherena e chegou em 1535 às Índias. Inicialmente, foi simples soldado no Panamá e na Colômbia. Chegou ao Peru em 1548, a serviço do pacificador La Gasca, na tropa de Benalcázar. Esteve na Batalha de Jaquijahuana e assistiu à execução de Gonzalo Pizarro e Francisco de Carbajal. Percorreu extensamente o país, anotando minuciosamente os dados que logo formariam parte de sua obra, concluída em 1550. Voltou à Espanha e entregou em Toledo o manuscrito ao príncipe Felipe. Passou seus últimos anos em Sevilha, onde morreu. Sua obra de cronista consta de quatro partes: a primeira é a chamada Crónica del Perú (1553), uma descrição geral do país; a segunda é El señorio de los incas, editada pela primeira vez em 
1873, e cobre a história do império; das duas últimas partes dedicadas às conquistas e às guerras civis, só se conhecem fragmentos.

\section{Pedro Pizarro (1515-1587)}

Nasceu em Toledo. Era primo de Francisco Pizarro e foi com ele para as Índias quando este firmou a capitulación de Toledo (1530). Esteve na fundação de Piura, na expedição a Cajamarca e na consequente captura de Atahualpa. Esteve também entre as hostes que marcharam para Cuzco e defendeu a cidade, junto com Hernando Pizarro, perante o ataque de Manco Inca. No grupo do conquistador do Peru, lutou contra Almagro em Las Salinas (1538). Ganhou uma encomienda em Tacna e obteve terras e índios em Arequipa, a cuja fundação assistiu. Em troca, a sua posição foi ambígua ante Gonzalo Pizarro: como se negou a respaldar o vice-rei Blasco Núñez Vela, que saiu a atacar o rebelde, esteve a ponto de perder a vida na vitória do vice-rei. Sofreu desterro em Charcas e ali apoiou o pronunciamento de Diego Centeno. Derrotado com este na Batalha de Huarina (1547), fugiu e participou com as forças de La Gasca na batalha de Jaquijahuana (1548). De novo de posse de seus bens em Arequipa, retornou em 1555 e 1571, onde morreu de avançada idade. Em 1571 escreveu a sua Relación del descubrimiento y conquista de los reinos del Perú, trabalho que empreendeu por sugestão do vice-rei Toledo. Essa obra foi publicada pela primeira vez em Madri, em 1844.

\section{Pedro Sarmiento de Gamboa (1532-1592)}

A vida desse cronista não pode ser mais novelesca e fascinante. Foi, ao mesmo tempo, matemático, astrólogo, cosmógrafo, navegante, historiador, estudioso de línguas clássicas... Nasceu em Alcalá de Henares, onde também estudou. Aos 18 anos, era já um navegante e soldado em campanhas de Flandres e Itália. Em 1555, viajou para o México. Viveu na Guatemala até 1557. Com problemas com a Inquisição, abandonou a região e foi para o Peru nesse mesmo ano. Ensinou gramática e foi processado pelo arcebispo Jerônimo de Loayza, acusado de exercer artes mágicas (1564). Foi obrigado a abjurar e a fazer grande penitência num convento dominicano. Con- 
seguiu permissão para resistir em Cuzco (1565). Envolveu-se na expedição de Álvaro de Mendaña (1657), que descobre as Ilhas Salomão. O vice-rei Toledo nomeou-o cosmógrafo-mor e historiador do Peru, onde esteve em sua viagem oficial a Cuzco e na guerra contra os chiriguanos. Foi novamente processado pela Inquisição (1574). No entanto, isso não impediu que o vice-rei o incluísse no grupo que tinha como objetivo prender o pirata Francis Drake, em 1579. Explorou o Estreito de Magalhães, cruzou-o em 1580 e seguiu até a Espanha: o rei o premiou autorizando uma nova viagem. Em suas desafortunadas tentativas de colonizar as ilhas dessa região, foi preso por uma embarcação inglesa em 1586. Mais tarde, foi prisioneiro dos huguenotes e resgatado por intervenção do rei Felipe II. Seriamente doente, chegou a Madri em 1590. Tentava uma nova expedição à Nova Espanha, quando morreu em Sanlucar de Barrameda. De sua Historia de los incas, escrita em Cuzco em 1572 e publicada em espanhol, em 1942, só se conhece a parte relativa ao Peru.

Pero Sancho de Hoz (1514-1547)

Não se sabe exatamente onde Hoz nasceu. Há indícios de que chegou às Índias com Pizarro, depois de que este firmou a capitulación de Toledo (1529). Foi secretário e escrivão do conquistador entre 1533 e 1534, na ausência de Francisco de Xerez, e continuou, por ordem de Pizarro, a relação que Xerez havia começado. Como soldado, participou da jornada de Cajamarca e da prisão de Atahualpa. Seu nome figura entre os que repartiram o resgate do Inca. Sua lealdade com Pizarro não parece muito certa: em 1535 conspirou contra o seu chefe por causa de umas ordens dadas pelo conquistador em Cuzco. Nesse mesmo ano, viajou para a Espanha, onde esteve envolvido num processo sob dinheiro das Índias. Sancho foi nomeado regedor de Toledo e casou-se com uma dama nobre. Decidiu voltar à América e ofereceu seus serviços a Carlos V para descobrir novas terras ao sul de Magalhães. De volta às Índias desde 1539, participou da expedição que Pedro de Valdivia organizara para a conquista do Chile. Disputou seus direitos com Valdivia, conspirou contra ele e finalmente foi decapitado em Santiago. O original da sua 
Relación para S. M. de lo sucedido en la conquista y pacificación de estas províncias de la Nueva Castilla se perdeu; as versões modernas em espanhol (a primeira data de 1849) são traduções da edição italiana de Ramusio (1550).

Titu Cusi Yupanqui (1526?-1570)

Foi filho de Manco Inca e o terceiro dos incas de Vilcabamba. Tomou o cargo de governador dessa zona quando o seu irmão, Sayri- Tupac, aceitou o gesto conciliador do vice-rei Hurtado de Mendoza (1557). Com a morte de Tupac, houve a rebeldia ao governo espanhol, com incursões armadas em Cuzco e Huamanga. Por meio da intervenção Lope García de Castro, Titu Cusi entregou dois memoriais à autoridade nos quais expunha suas queixas pelos maus-tratos sofridos por seu pai e as condições para abandonar sua posição. Após uma discussão, aceitou que os missionários catequizassem os índios de Vilcabamba e ele próprio recebeu o batismo (1568). Ditou uma relação baseada em memórias de sua vida imperial, dirigida ao governador. Pouco depois morreu de uma pneumonia. Sua Relación de la conquista del Peru y echos del Inca Manco II data de 1570 e foi ditada ao frade Marcos García. Essa obra foi publicada em Lima, em 1916. 
204 ANA RAOUEL PORTUGAL

\section{Anexo 3}

\section{Mapas}

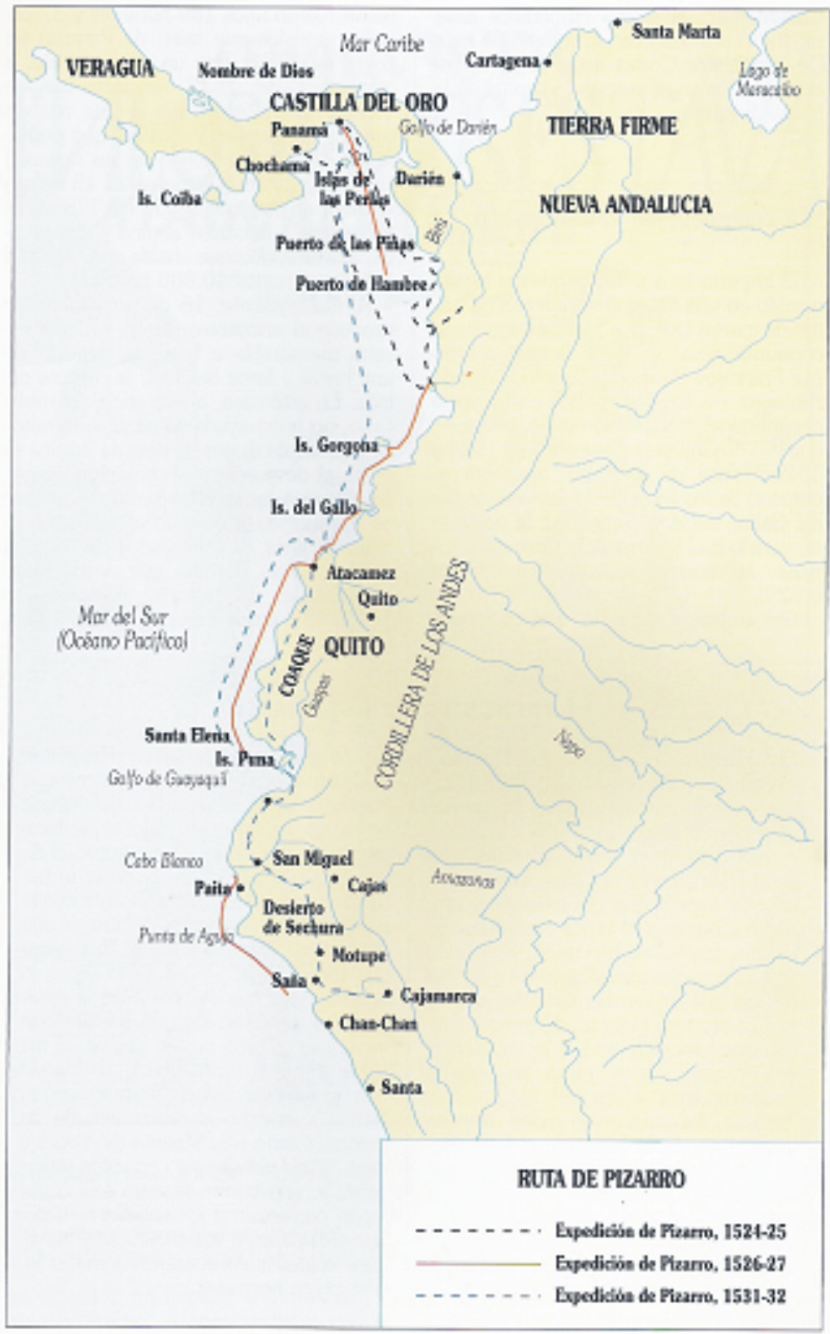




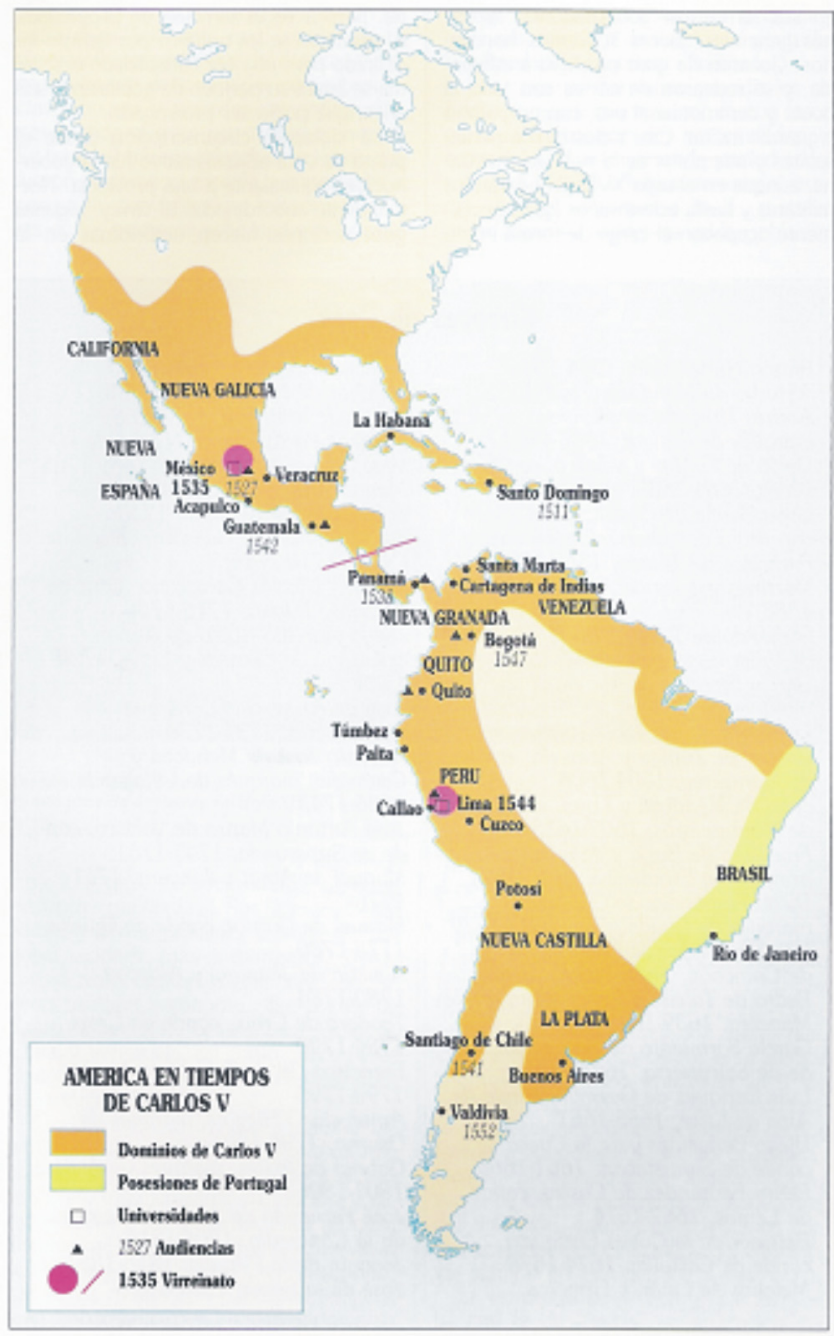

Fonte: Cuetos (1996, p.31, 91). 



\section{GLOSSÁRIO}

Aclla: escolhida.

Aclla huasi: casa das escolhidas.

Ayni: sistema de serviços mútuos.

Camayoc: oficial que tem a seu cargo fazendas ou alguma chácara.

Capac: pessoa rica e poderosa. Capaccocha: sacrifício especial às huacas; às vezes humano.

Ceque: linhas, término. Em Cuzco, irradiavam linhas imaginárias do Templo do Sol, e em cada uma delas se situava um número de huacas a cargo de determinados ayllus.

Conopas: objetos sagrados caseiros.

Coya: rainha, a esposa principal. Curaca: senhor principal de um povo.
Chasqui: o mensageiro, palavra usada em Cuzco.

Guanca: pedra. Pode se referir a um personagem transformado em pedra e sacralizado.

Guaranga: o número mil; em um sistema organizativo, mil lugares.

Hatun o atun: coisa grande ou superior.

Hatun curaca: senhor, o chefe de uma macroetnia.

Hatun runa: homem grande; quando o homem se casava e assumia a plenitude da sua idade.

Huaca: o guaca, templo do ídolo ou o próprio ídolo.

Llacta: povoado.

Mallqui: corpo mumificado de um antepassado a quem se 
entregavam oferendas ou se venerava.

Mascapaycha: coroa, insígnia do inca reinante.

Mindala: índios comerciantes da região de Yumbo no Equador pré-hispânico.

Minka: sistema de trabalho ou cumprimento de obrigações por substituição.

Mitmaq: o mitimae; pessoas enviadas a um lugar estranho para cumprir uma tarefa estatal.

Mita o mi'ta: vez, turno, tempo, periodicidade.

Pacarina: lugar de origem.

Pachaca: número cem no sistema de organização decimal.

Pururauca: pedras que se convertiam em guerreiros segundo a mitologia.

Quipu: corda de diferentes cores e nós que servia para contabilizar objetos e também feitos históricos.

Quipu camayoc: o encarregado dos quipos.

Runa: pessoas, o homem.
Runa simi: a linguagem do homem.

Sapa inca - de sapa: grande. Inca principal sobre os demais.

Sinchi: chefe guerreiro.

Suyu: parcialidade; hanan suyu, parcialidade de cima; hurin suyu, parcialidade de baixo.

Tampu: pousada, casa; palavra usada pelos espanhóis: tambo.

Taqui: canto, dança.

Taqui aclla: classificação das mamaconas; jovens cantoras.

Tocrituc: personagem que tem a seu cargo o povoado ou um número de pessoas.

Tupu: medida de área e de longitude; também o verbo medir.

Villca: coisa sagrada, divina; árvore determinada; no quechua da costa, villca $=$ ayllu (Domingo de Santo Tomás).

Villac umu o villaoma: sacerdote máximo do Sol.

Yana: o servidor, o criado que serve.

Yunga o yunca: os habitantes da costa. 
SOBRE O LIVRO

Formato: $14 \times 21 \mathrm{~cm}$

Mancha: 23,7 x 42,5 paicas

Tipologia: Horley Old Style 10,5/14

1ạ edição: 2009

EQUIPE DE REALIZAÇÃO

Coordenação Geral

Marcos Keith Takahashi 



\section{CULTURA}

$\frac{\text { ACADÊMICA }}{\varepsilon d i t o n a}$ 